\title{
CIFOR
}

Claiming the Forest

Punan Local Histories and Recent Developments in Bulungan, East Kalimantan
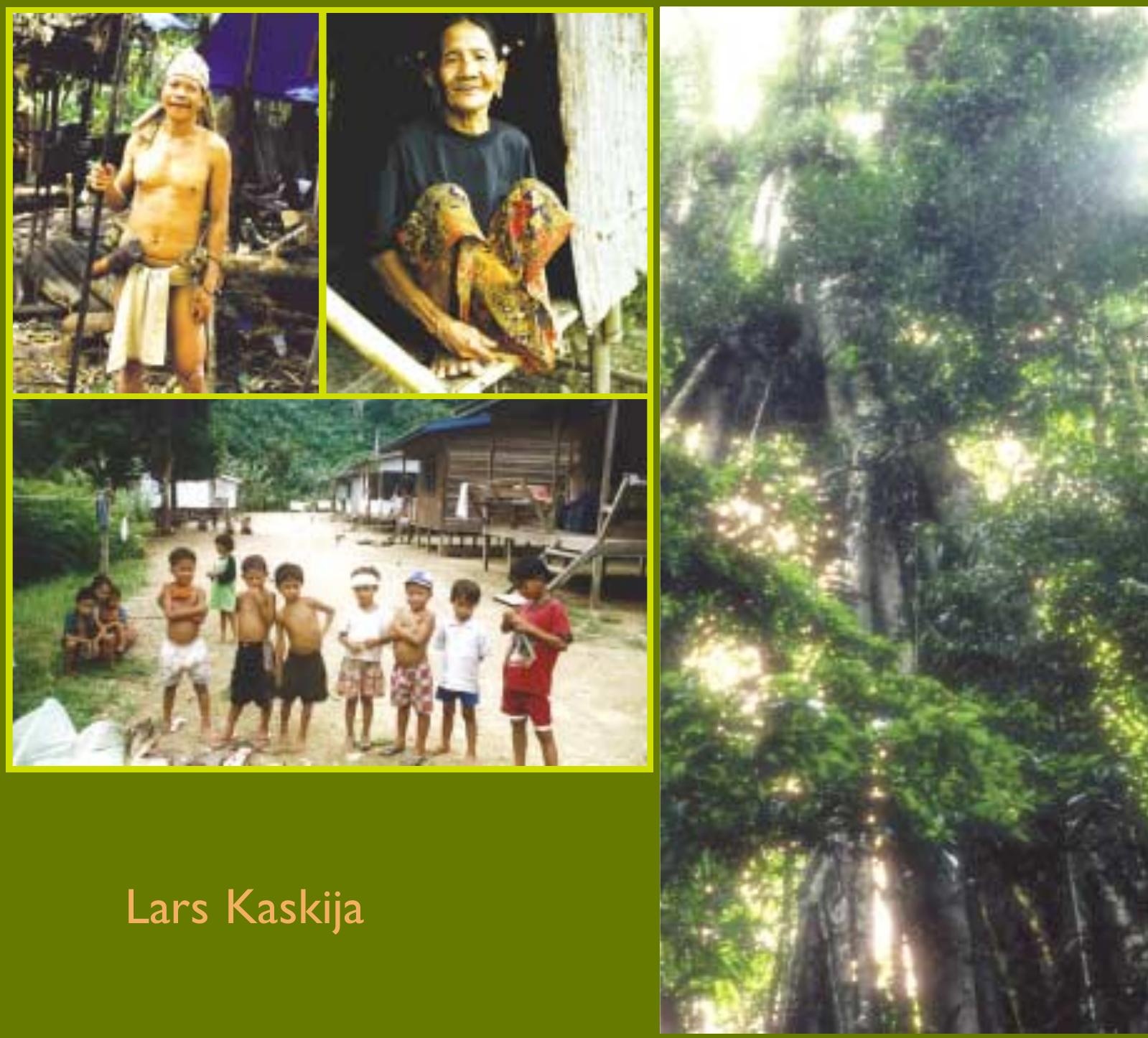

Lars Kaskija 


\section{CLAIMING THE FOREST}

Punan Local Histories and Recent Developments in Bulungan, East Kalimantan

Lars Kaskija 
Financial support from the International Tropical Timber Organization (ITTO) through the Project PD 12/97 Rev.1(F), Forest, Science and Sustainability:

The Bulungan Model Forest is gratefully acknowledged

(C) 2002 by Center for International Forestry Research

All rights reserved. Published in 2002

Printed by SMK Grafika Desa Putera, Indonesia

ISBN 979-8764-90-0

Published by

Center for International Forestry Research

Mailing address: P.O. Box 6596 JKPWB, Jakarta 10065, Indonesia

Office address: JI. CIFOR, Situ Gede, Sindang Barang,

Bogor Barat 16680, Indonesia

Tel.: +62 (251) 622622; Fax: +62 (251) 622100

E-mail: cifor@cgiar.org

Web site: http://www.cifor.cgiar.org

Photo Credits

Cover:

Punan hunter of the Tubu river, wearing traditional clothing used in the past for blowpipe hunting,

Long Nyau •Edmond Dounias

Old Punan woman, Long Nyau • Edmond Dounias

Nowadays, Punan hunter gatherers settle down in permanent villages •Patrice Levang

Epiphytic Ficus species strangling its host tree, Tubu river • Edmond Dounias

Page 12 •Patrice Levang; Pages 13, 14 •Nicolas Césard; Page 25 •Christophe Kuhn; Page 27 •Patrice Levang; Page 29 •Nicolas Césard; Pages 30 •Patrice Levang; Pages 32 •Christophe Kuhn; Pages 33 •Patrice Levang; Pages 36 •Christophe Kuhn; Pages 66, 75, 78, 80, 94 •Patrice Levang; Page 96 •Nicolas Césard 


\section{Contents}

Preface vi

1. Introduction 1

2. An Ethnic Sketch 7

2.1. The Merap 7

2.2. The Kenyah 8

2.3. The Abai (Tebilun) 9

2.4. The Putuk (Lun Daye) 10

2.5. The Punan 11

3. Punan Settlements and Subsistence in Upper Malinau 17

3.1. Punan villages in upper Malinau $\quad 17$

3.1.1. Punan Halanga 19

3.1.2. Punan Mirau 20

3.1.3. Punan Long Rat (Hangrat) 20

3.1.4. Punan Metut 21

3.1.5. Punan Pelencau 22

3.1.6. Punan Lake 23

3.1.7. Punan Long Jalan/Punan Arah 24

3.2. Punan Malinau subsistence 24

3.2.1. Agriculture 25

3.2.2. Wild food resources 26

3.2.3. Wage labor and cash crops 31

3.2.4. Non-Timber Forest Products (NTFPs) and trade 32

3.2.5. The role of women 35 
4. An Ethnohistoric Sketch 37

4.1. Whose history? 37

4.2. The growing political significance of historical data 38

4.3. Early inhabitants of the area $\quad 40$

4.3.1. The Ngurik 40

4.3.2. The Berusu' 40

4.3.3. The arrival of the Merap 42

4.3.4. The establishment of Merap dominance in the Malinau area 44

4.4. The ethnohistory of the Langap Merap $\quad 45$

4.5. Other groups of Merap 50

4.6. The Punan 52

4.6.1. Problems regarding historical reconstructions 52

4.6.2. Are all Punan from the Tubu'? 53

4.6.3. Punan Beketan 55

4.6.4. Punan Arah 58

4.6.5. Do all Punan have a common

4.7. The arrival of the Kenyah 60

5. Ethnicity and Political Leadership 61

5.1. Identity and ethnicity 61

5.2. Settlement patterns 63

5.2.1. The family and the band nomadism and village life 63

5.2.2. 'Isolated peoples' and resettlement 66

5.3. Local variation 68

5.4. Leadership 71

6. Recent Trends and Perspectives 73

6.1. Health 74

6.2. Progress and cultural autonomy 77

6.3. Land rights and territoriality 79

6.3.1. The Merap 81

6.3.2. Territory and landscape 83

6.3.3. Conservationists? 86

6.3.4. Return to Tubu' 87 
6.4. Assistance, charity, aid and compensation $\quad 89$

6.5. Cultural reflexivity 91

6.6. Growing political awareness 93

$\begin{array}{ll}\text { Endnotes } & 97\end{array}$

$\begin{array}{ll}\text { Bibliograhy } & 103\end{array}$

Maps

1. Malinau and the Bulungan Research Forest 2

2. Settlements in the upper Malinau 18

3 The Malinau watershed and neighbouring areas 51

\section{Tables}

1. Merap villages in the Malinau district in 1990

2. Kenyah villages in the Malinau district in $1990 \quad 9$

3. Number of houses and households in upper Malinau, Feb. 2000

\section{Appendices}

1. Population figures according to Padan and Laway (1999)

2. Kecamatan Malinau: Population and ethnic groups (1990)

3. The genealogy of Mpang Alang 112

4. Genealogy Punan Pelencau 115

5. The genealogy of Ncau Usat, Long Uli (Punan Metut)

6. Genealogical relationship between Mbui and Bare' Tangga'

7. The genealogy of Maring (Punan Beketan) 


\section{Preface}

Fieldwork for the present study was carried out from January 27 to February 25, 2000, in the upper reaches of the Malinau and Ran rivers. The study was undertaken as a short-term anthropological consultancy for CIFOR (Center for International Forestry Research). During fieldwork I was based at CIFOR's guesthouse in the village of Long Loreh, although I spent most of the time in villages and settlements further upstream, i.e. Long Uli, Liu Mutai, Long Metut, Long Kirau, Long Jalan, and Long Mirau.

I previously conducted research in the Malinau-Tubu area in 1990, 1991, 1992, and 1997. All in all, I have spent approximately 15 months in various settlements along the Malinau, Tubu, Ran, and Hong rivers. In my research, I have focused in particular on the largest indigenous group in the area, the Punan.

The main points of my terms of reference were to present information on the economic behaviour of the Punan and to give more detail on the ethno-history of the area, as well as to focus on some of the changes that have occurred in the area during the past 10 years. In my previous report to CIFOR of December 1999, I particularly focused on certain aspects of Punan economic behaviour (Kaskija 1999b). Although this report also contains information about economic behaviour, I have tried not to repeat myself. 


\section{Introduction}

he local indigenous population in the Bulungan Research Forest (hereafter BRF) area is comprised of representatives of several ethno-linguistic categories, such as Merap, Punan, Kenyah, Putuk, and Abai. In addition to these indigenous Dayak groups, there is also a large Malay (Islamised Dayak) population, most of whom are living just outside the boundaries of the BRF, but close to the district capital of Malinau.

The district of Malinau covers the Malinau River and its major tributaries. According to official statistics, the Malinau district had more than 17,000 inhabitants in 1990 — including the population in the Tubu area - of whom almost 10,000 were living in or very close to the district town of Kota Malinau. At that time there were approximately 3500 Punan living in the district of Malinau, less than 1000 of them still living far upstream. It is difficult to say whether these figures are correct, as some villages are of mixed ethnic composition. Interpreted in another way, the number of Punan was probably less than 3000 in 1990 (see Appendix 2).

In 1990 almost 1200 Punan Tubu lived in resettlement villages close to the district capital of Kota Malinau, at least 600 Punan Tubu/ Malinau lived in the most accessible middle or lower part of the Malinau River, approximately 500 Punan Malinau/Tubu were still living in upper Malinau (including the Ran and Hong rivers), and another 450 (Punan 


\section{INTRODUCTION}

Map 1. Malinau and the Bulungan Research Forest

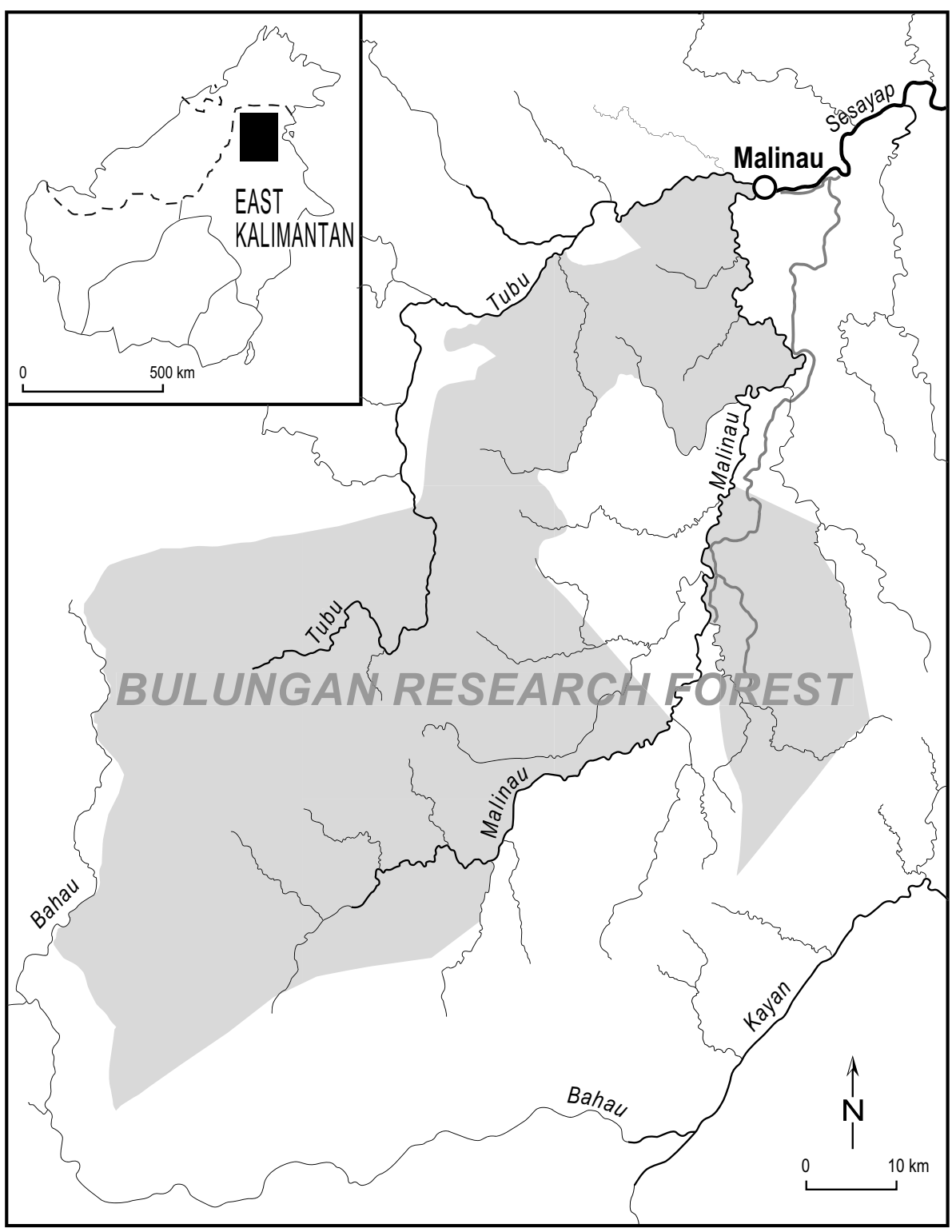


Tubu) in upper Tubu. These were the official figures, given by the district office in Malinau in 1990-91. Although I do not have the population figures for 1999, it is interesting to note that at least as many Punan still reside in the upper parts of the Tubu and Malinau rivers today as did 10 years ago. Although the total population of the Malinau area is increasing rapidly today, it has had a very low population density, and this applies especially to the upper reaches of the Malinau and Tubu rivers. In 1990, the Malinau district - which at that time also included the Tubu area - covered 8783 sq. $\mathrm{km}$. In 1997 this area was reduced to $5238 \mathrm{sq}$. km. as a consequence of the transfer of the Tubu area to the neighbouring Mentarang district. Based on these figures, the area had a calculated population density of 2 individuals per sq. $\mathrm{km}$ in 1990 (total population 18,000) and 3.8 per sq. $\mathrm{km}$. in 1999 (population 19,876). However, the area upstream of Long Loreh, which covers approximately one-third of the present district, has a population numbering 2247 individuals (Padan \& Laway 1999: 8), which means that the population density in this upriver area of the Malinau River is less than 1 per sq. $\mathrm{km}$. (ca. $0.7-0.8 / \mathrm{km}^{2}$ ).

The terrain of most of the Malinau district is very undulating, with a number of ridges reaching 2000 meters above sea level. Innumerable rivers and streams, many of them navigable by longboat, cross the whole area. The lower half of the Malinau River is easily accessible, and is therefore the main highway of the district, although the construction of roads has now begun to open up alternatives for transportation. Longboats, especially smaller ones, are used for the transportation of people and goods as far as Long Pada (Tubu), Long Jalan (Malinau), Kuala Nit (Ran), and Lian Utun (Hong). In 1990-92 almost all of the Malinau area was still densely forested. Along the easily navigable parts of the major rivers the forest was secondary, in different stages of regeneration. On the slopes on both sides, particularly close to villages, were small- to medium-sized rice fields, surrounded by patches of banana trees and some cassava. The area of cultivated land was highest downstream and close to larger villages.

At the beginning of the 1990s there were still no roads in the middle and upper parts of the Malinau and Tubu rivers. Logging was restricted to downriver areas or neighbouring areas outside the Malinau 


\section{INTRODUCTION}

district. Since that time, major changes have occurred. Timber companies have now exploited areas that were still primary forest in 1990, e.g., parts of the Hong and Sengayan rivers. Logging roads, as well as a few stretches of public roads, have improved communications significantly; these roads have reached the middle Malinau from several directions, and continue into the upper Malinau and Tubu areas. New bridges have been built quite far upstream, one at Long Uli in the upper Malinau and one close to the mouth of the Hong River.

In 1990-92 there were some roads, but none of them connected Malinau with the coast or with other towns farther to the south. Communication between Malinau and the coast was and remains by river, or by air. The timber roads were at that time mainly situated on the eastern side of the Malinau River, connecting Kota Malinau and Bengalun with Gong Solok. Another road connected the middle Malinau (Kelawit River) with timber camps on the lower part of the Kayan River farther to the south. Also, logging was mainly restricted to the eastern, lower side of the Malinau River, with the exception of a network of logging roads under construction on the western side of the Malinau River starting at the village of Batu Kajang.

The arrival of a growing number of powerful outsiders, such as timber and mining companies, has contributed to increasing competition for land and various products of commercial value. At the same time there are numerous plans to convert large tracts of forest into plantations and farmland. Forests are also continuously giving way to various forms of infrastructure, such as residential areas, roads and bridges. Better communications and transportation have increased the 'metabolism' of the region - and will do so even more in the years to come.

It has been estimated, that the number of forest dwellers in Southeast Asia amounts to approximately 30 million people - all of them intimately dependent upon the resources of the forest for their livelihoods (De Beer \& MacDermott, 1989: 45). The number of forest dwellers in Malaysia and Indonesia alone amounts to approximately 770,000 and $7,500,000$ respectively (ibid.). The overwhelming majority of these are swidden cultivators, who normally receive most of their staple (primarily rice) from their own fields, while procuring most of their non-staple food 
(meat, fish, etc.), as well as material for construction, the making of tools, etc., from the nearby forests. The importance of the forest is generally much greater than presumed, even among many groups of wet rice agriculturalists, such as among the Tai in Central Laos, where 'physical survival would be quite possible without rice fields, but next to impossible without the forest' (Ovesen 1993: 27). A similar picture is drawn by Chin (1985) in his study of a Kenyah community in Sarawak, where 'gathering, hunting and fishing together provide between 47.6 to 64.4 percent of the non-staple items in this community, and are thus more important than agricultural activities' (De Beer \& MacDermott 1989: 54). In another study it is suggested that people in Sarawak annually consume as much as 18,000 tons of wild meat (12 kg/person) (ibid.). Non-Timber Forest Products (NTFPs), whether they are traded for cash and goods or consumed locally, represent an enormous wealth, especially if we calculate them in terms of the costs for substituting these resources, or the incomes generated by these products.

Gillis draws the conclusion that 'poor people in poor countries are far more dependent upon soils, fisheries, and forests than are the wealthy' (1991: 166). Therefore, any degradation of such soils, rivers, and forests 'involves more serious immediate consequences for the poor than for the wealthy. This is most obviously the case for the millions of people, typically cultural minorities, for whom tropical forests have been a traditional abode' (ibid.).

The local population of the BRF fits this description. The forest and its resources play a significant role in local economies, although the extent and composition of this role differ between various settlements and households. Besides agriculture and the necessities and incomes generated by the forests and rivers, there are still rather few alternative sources of local livelihoods. The number of companies has increased during the last decade, but these companies offer surprisingly few job opportunities to local people. Most employees are outsiders.

The BRF area has a low population density, with approximately five or six thousand individuals distributed over an area that is 300,000 hectares (i.e., around $2 / \mathrm{km}^{2}$ ). The reason why this area is still so rich in natural resources is, of course, related to this low population density and 


\section{INTRODUCTION}

the fact that major resources, such as timber and minerals, have largely remained untapped until recently. Timber companies entered the area before, but they seem to have faced serious financial obstacles and operations have been ineffective and of short duration. What is happening today is something that this area has not experienced before. The increase in the number of companies, as well as the influx of people from other parts of Indonesia, has increased competition for land and will do so to an even greater extent in the years to come. With a reduction in the forest cover, increased siltation of rivers and so on, this will have a serious effect on local economies. Today most communities produce and procure most of the food resources they need, but this will be increasingly difficult. An important question is what the costs will be to the next generation. The present struggle for land rights must be seen in light of these questions.

The area has increasingly become the focus of outside attention. A growing number of local and international NGOs, organizations with different agendas, most of them dependent upon the taps of international funding for biodiversity, sustainability, and development; tourists, although still few in number; researchers; timber and mining companies - all have been drawn to the area. Whatever their motives for coming here, the area is clearly of interest to these outsiders. Important questions in this context are, e.g., in what way can local people profit from this interest, or at least have a say in affairs that obviously affect them in one way or another? To what degree and in what terms can local people participate and have a say, on equal terms, with various outside agents? Despite the presence of local NGOs and organizations aiming at supporting and strengthening local communities' claims, there is much conflict and split among local people. A disturbing fact is the growing individualization of economic strategies among local people, as well as the prevalence of corruption at all levels, and the lack of cooperation between villages for common goals. The picture becomes extremely complex and problematic. However, even if this is the case and even if local action is often generated by personal gain, the local people's claims to a fair share and to be able to participate on equal terms are just as legitimate. 


\section{An Ethnic Sketch}

Delow is a brief presentation of the major ethnic groups within the BRF. The population figures are based on statistics from the district office in Malinau, and from the data I collected in the field in 1990-91.

\section{I. THE MERAP}

The Merap are socially stratified swidden cultivators. The members of Merap villages are divided into paran (aristocrats, nobles), panyin ('commoners', constituting the village majority) and, formerly (until the second quarter of the $20^{\text {th }}$ century), $l u$ ' $a$ (slaves, usually war captives owned by village chiefs). The status of an individual was formerly marked, e.g., by specific tattoos for men and women of paran or panyin status.

Village chiefs and war leaders were always paran. A village chief has normally been succeeded by one of his own sons and the village majority has had very little influence in these matters. The system of inequality that has characterized the Merap has been, not only ideological, but political and economic as well.

Marriages among the Merap do not include the payment of bride price. However, like many other local groups, the Merap practiced secondary burial of the dead until the late 1960s. 


\section{An ETHNIC SKetch}

Table 1. Merap Villages in the Malinau District in 1990

\begin{tabular}{llr}
\hline Village & Comment & Population \\
\hline Long Kendai & Village in Respen Sembuak & 94 \\
Sentaban & Only a few Merap & 30 \\
Gong Solok & Also Kenyah Leppo' Ke, Nyibun & 100 \\
Long Adiu & Also Punan & 97 \\
Sengayan Loreh & Also Kenyah and Punan & 125 \\
Nunuk Tanah Kibang & Mixed with Punan Kibang & 136 \\
Laban Nyarit & & 86 \\
Langap & & 364 \\
Seturan & Also Punan and a few Leppo' Kuda & 63 \\
& Total & 1095 \\
\hline
\end{tabular}

In 1990 there were approximately 1100 Merap in the Malinau area, about 10 percent in Respen Sembuak and the rest along the Malinau River, with the highest concentration, or approximately 500, in Kuala Ran (Langap and Nanuk Tanah Kibang).

There are no Merap villages in the Tubu today, as the only village (Long Kendai) resettled to the Malinau River (Nanuk Tanah Kibang) and to Respen Sembuak in 1971-75. Along the Malinau River, on the other hand, there are several Merap villages, most of them ethnically mixed.

\subsection{THE KENYAH}

The Kenyah is a large, but very heterogeneous, category of socially stratified swidden cultivators distributed all over Central Borneo. They are, or at least were, stratified into paren (aristocrats), panyen (commoners), and, formerly, kula'(slaves). Although there are several groups of Kenyah living along the Malinau River today, most of them except the Leppo' Kuda in Seturan — migrated to the area in the 1960s and 1970s. They all come from the Bahau and the Pujungan area farther to the west. The Kenyah (as well as the Putuk) are the most successful agriculturists within the district. 


\section{An ETHNIC SKetch}

It is rather difficult to estimate the number of Kenyah living within the district of Malinau, as many villages are of ethnically mixed composition. One problem concerns the village of Liu Mahan, which was actually a Punan village. These Punan joined with the Kenyah, who are much more numerous. It is, however, possible that the Kenyah amounted to at least 1500 souls in 1990, which means that they were more numerous than the former 'masters' of the Malinau area, the Merap.

There are Kenyah in the following seven villages along the Malinau River:

Table 2. Kenyah Villages in the Malinau District in 1990

\begin{tabular}{llr}
\hline Village & Comment & Population \\
\hline Setulan & Uma' Lung (from Pujungan 1964-65) & 681 \\
Setarap & Uma' Lasan (from Pujungan 1964-65) & 30 \\
Batu Kajang & Uma' Lung, Leppo' Ndang (from Pujungan 1962) & 244 \\
Gong Solok & Leppo' Ke, Nyibun (from Bahau 1972-1975) & 40 \\
Long Loreh & Leppo' Ke (from Bahau 1972) & 400 \\
Paya Seturan & Leppo' Kuda (from Lurah ca 1840) & $?$ \\
Tanjung Nanga & Pua' (from Pujungan late 1960's). & 270 \\
& Total & 1665 \\
\hline
\end{tabular}

\subsection{THE ABAI (TEBILUN)}

The Abai lived on the middle and lower Tubu until 1970, when they all moved downriver to Respen Sembuak or Sentaban. Nominally they are just as socially stratified as the Merap or the Kenyah. They do recognize various social strata and they regularly refer to their leaders as raja. The Abai recognized and classified people in different and hierarchically ordered categories. They distinguished between raja belayan (village chief, i.e., a single person), panyin (commoners), and rifon (slaves, usually war captives). Just as among the Merap, tattoos were markers of status, among men as well as among women. Despite this system (and the ideology) of stratification, in practice the Abai system was rather different from that characterizing the Merap. It was, as Sellato (1997) has argued for the Lun Daye, 'a highly competitive system'. 


\section{AN ETHNIC SKetch}

Intermarriage between Abai and other groups, such as Punan or Milau, was frequent. Various groups often lived together in the same settlements on the Tubu. A village like Long Nit (presently situated in Respen Sembuak) was actually composed of several ethnic groups that intermarried, i.e., Abai, Milau, and Punan. There were, of course, also Punan groups living farther inland, usually along smaller tributary streams, and these Punan traded with the leaders of Abai and Merap villages, and in this regard the relationship resembled that between Punan and Merap in the Malinau, but the boundary between these groups was less marked along the Tubu. What Sellato has written in reference to the Lun Daye can also be said about the Abai, namely that 'rich families competed with one another for prestige and status in lavish feasts (irau) of secondary funerals in which they invested most of their wealth' (Sellato 1997).

\subsection{THE PUTUK (LUN DAYE)}

Putuk are swidden and wet rice cultivators. They are the most numerous group in the Kerayan Highlands. At the end of the 1970s there were approximately 35,000 Lun Daye, of which 25,000 were living in Kalimantan (many of them known as Putuk) and 10,000 in Sarawak (Crain 1978: 123). ${ }^{1}$ The Lun Daye, or Putuk, have also been characterized as socially stratified, although their system may be more correctly characterized as 'highly competitive' (Sellato 1997).

Many of them are devoted Protestant Christians today. As did many other ethnic groups in the area — including all the other Apo Duat groups (Milau, Tembau, Berau, Saben) - they traditionally practiced secondary burial of the dead, and marriage includes payment of a bride price.

The Putuk may have been one of the first inhabitants of the areas surrounding present-day Kota Malinau. Their name is derived from the Putuk or Seputuk River, a tributary of the Sesayap River. From this area they moved up the Mentarang and settled in different parts of the Kerayan Highlands (cf. Sellato 1995b). There are currently several Putuk living within the Malinau area, particularly in Pulau Sapi (approximately 


\section{AN ETHNIC SKetch}

874 in 1990) and Lidung Keminci (approximately 215). Those living in Setarap moved from the Mentarang River to their present location around 1900. The Punan living in Setarap arrived later, probably around 19201930, from Long Tebunyau on the lower Tubu. Putuk is the preferred ethnonym, as Lun Daye "only means 'the people upriver' in our language", as one Lun Daye informant expressed it.

Linguistically related groups include the Milau, Tembau (or Tempuu), and Merau (or Berau). There are no pure Milau villages, but there are a few Milau individuals living in Respen Sembuak (Long Nit), Sentaban on the lower Malinau (previously Long Bila', Tubu), Langap, Tanjung Lapan, and Limbus Dulun (Tidung Pala). Milau are often said to be the same as Tembau. Some Tembau are living in Respen Sembuak, Nanuk Tanah Kibang, and Langap. In the past they lived in Long Kendai, a Merap village in upper Tubu, and some also in Long Bila', a Tebilun village in the Tubu.

There are currently no Merau villages in District Malinau, but individual Merau are living in villages such as Respen Sembuak, Sentaban. Punan Tubu usually call them wang Berau (the Berau people), after the name of a river on the upper Bahau.

\subsection{THE PUNAN}

In 1969, government officials recorded 23 Punan villages, with a population of 1,610 within the Malinau district, i.e., approximately 30 percent of the villages and 10 percent of the whole population were Punan at that time (Rousseau 1988: 10). In 1990, according to the same administration, the Punan constituted as much as 17 percent of the total population within the district.

In other areas of Central Borneo, the nomads have usually been only a small minority, surrounded by large and powerful groups of agriculturalists. In the Apo Kayan in 1938, for instance, there were only 228 nomads out of a total population of 16,656 (Rousseau 1988: 9). In 1970, on the other hand, there were 484 Punan living in the Apo Kayan, but as many as 12,037 Kenyah and Kayan (Whittier \& Whittier 1974: 7). 


\section{AN ETHNIC SKetch}

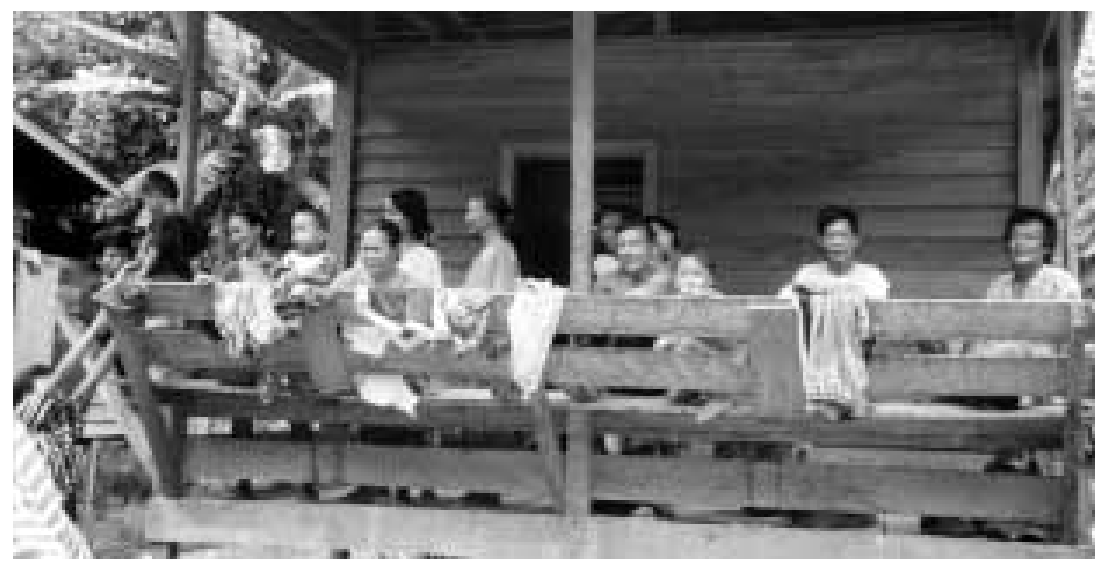

Punan Malinau from Long Jalan in the upper Malinau

In Sarawak, Punan and Penan constituted, in 1970-71, approximately 10 percent of the total Dayak population (Kayan, Kenyah, and Kajang) in the Balui (Rousseau 1974; Chen 1990: 6) and Baram areas (Metcalf 1974).

The number of Punan living upstream - i.e., above resettlement areas such as Loreh, Kuala Ran, Seturan, and now also Tanjung Nanga — is roughly the same today as ten years ago, in 1990. The major difference is that today the majority of households live in settlements, while the number who live permanently at their swidden fields or who regularly spend long periods of time in the forest has decreased during the last decade.

Punan in the Malinau/Tubu do not constitute one single group, although most of them may very well share a common origin (see section 4.6.5.). They are nonetheless quite heterogeneous and there are important differences between groups and individuals. As a group they do not physically differ from the other peoples in the region. To distinguish a Punan from a non-Punan on the basis of physical appearance is difficult and unreliable (Punan Malinau), or altogether impossible (Punan Tubu). In their interactions with the world around them, individual Punan vary greatly.

In reference to the Malinau area, two sets of factors are of special importance to the discussion of local variation between various groups of Punan. One is the location of settlements - downriver or 


\section{An ETHNIC SKetch}

upriver - as location affects the availability of various resources and opportunities. Another set of factors behind the local variation found among different Punan settlements is political and historical. Each Punan settlement or band, in the Malinau or Tubu areas, has its own history of alliances, fusions, and fissions, and within each there is much variation. In the general presentation below I have divided the local Punan into four categories or subgroups:

\section{Punan from the lower and middle Tubu}

These Punan, as well as those on the Mentarang River, were affiliated to, in particular, the Abai of the Tubu (and Mentarang), but also with a number of smaller groups, such as Milau, Merau, and Merap (of Long Kendai). In 1990, only two villages (pop. 149) remained in the (lower, middle) Tubu (i.e., Rian Tubu and Long Titi). The majority (13 villages, 987 individuals) resettled downriver in the 1970s to Respen Sembuak and Lubuk Manis. Two villages (pop. 236) also resettled in the early 1970s to the middle part of the Malinau River (Bila' Bekayuk and Long Rat). In addition, a number of families (approx. 15) also moved to $\mathrm{Pa}$ Upan in the Kerayan in 1966 and later. The most outspoken, politically aware and well-educated Punan are to be found within this category.

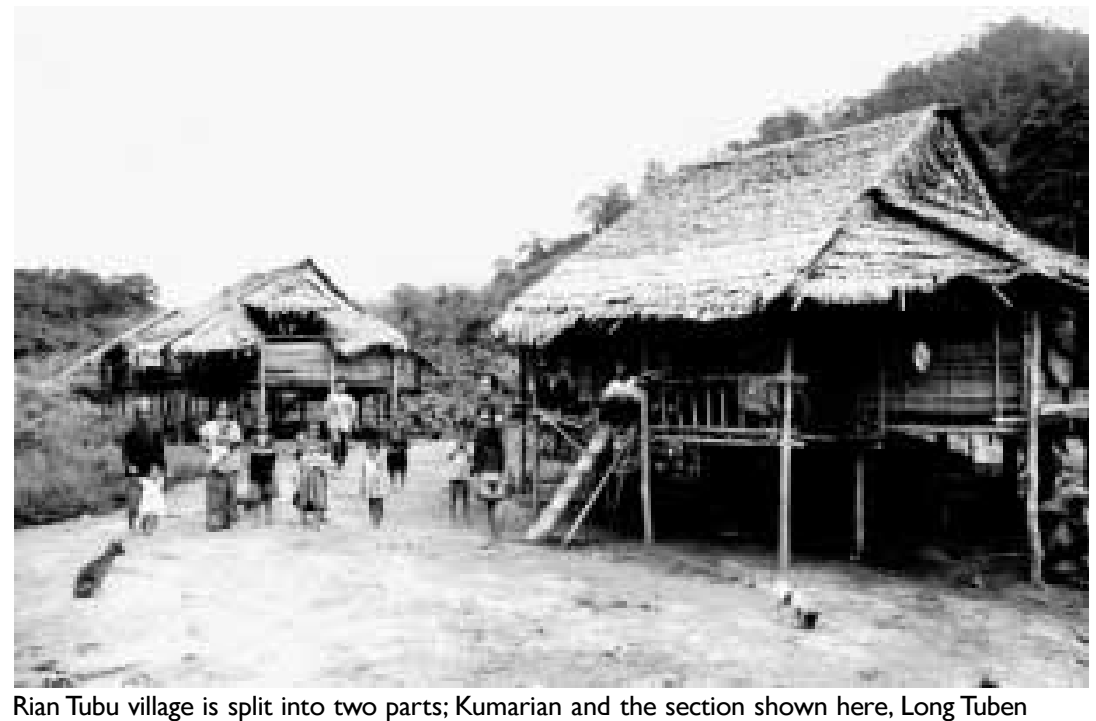




\section{AN ETHNIC SKETCH}

Punan Tubu demand a payment of bride price (B.P., tiran) ${ }^{2}$ for their daughters, just as the Abai or Milau have (but contrary to the Merap). Some of these groups practiced secondary burial (B.P., nulang) in the past. These Punan are thus very much intermixed with groups of nonPunan, especially Abai, and they are also culturally influenced by them (e.g., bride price).

\section{Punan from the upperTubu}

The Punan of the uppermost Tubu have not resettled downriver. They comprise three villages, Long Pada, Long Nyau, and Long Ranau, with a total population of approximately 300 individuals in 1990. These Punan have had close relations with the Kenyah of the Bahau for more than a century now. This may be one reason why they differ to some degree from other Punan groups in the Tubu or Malinau. The Kenyah Leppo' Ke of the Ngian River (Long Lat) have long been in contact with the Punan of upper Tubu. These Punan groups were often split and moved around according to their patrons' needs. For example, the Punan of the upper Tubu seem to have been split between the Leppo' Ke of the Ngian River and the Merap of Tubu-Ran-Malinau. These Punan can therefore

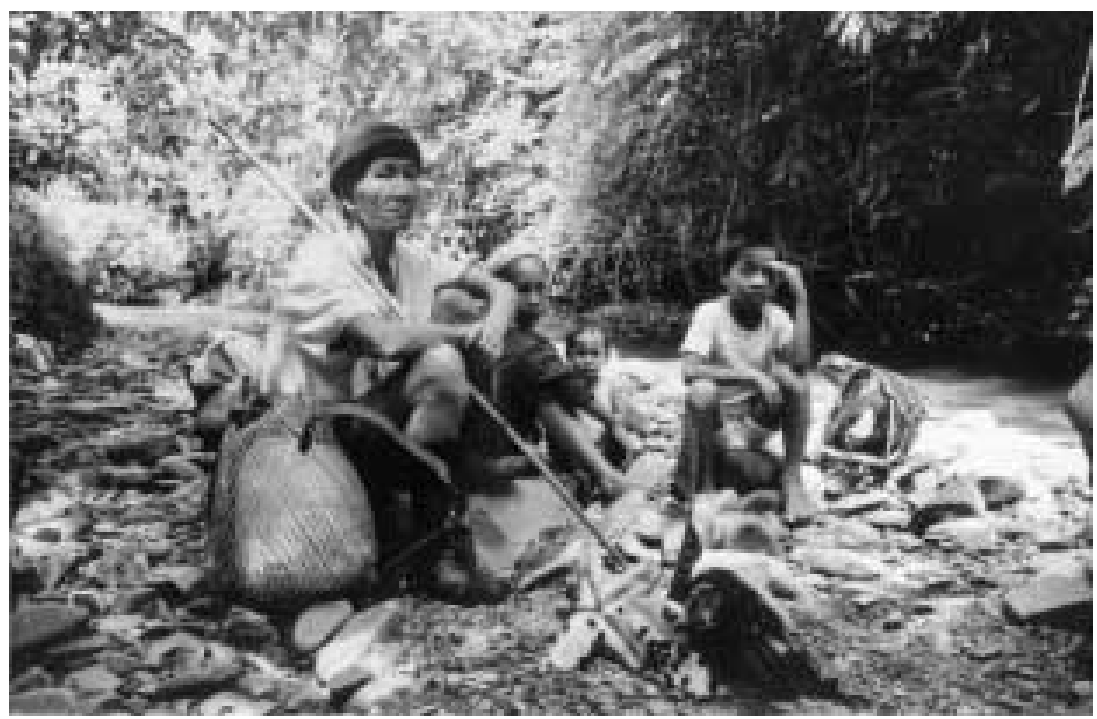

A family resting on the way to Long Titi in the upper Tubu 


\section{AN ETHNIC SKetch}

also speak Kenyah fluently and they are culturally much influenced by the Kenyah. Some of the Punan - men and women - from Long Nyau and Long Ranau have also married Kenyah. Many households in these villages plant regularly up to 1-2 hectares of rice per year (Njau Anau, pers. comm.). The Punan of upper Tubu also demand a payment of bride price for their daughters. The Punan of upper Tubu buried their dead immediately and did not practice secondary burial.

\section{Punan Malinau}

Punan groups that have been living along the Malinau River have been affiliated to the Merap (pop. 910 in 1990), or the Putuk (pop. 104 in 1990). This also includes the Punan Mirau of the Ran River and their present neighbours, the Punan Halanga. The latter group, Punan Halanga, actually moved from upper Tubu some 40 years ago, but could be included in this category mainly as they have so much in common with the Punan Malinau. The Punan of the upper Malinau have long been very much subservient to the Merap. Some of these Punan were used by the Merap as watchdogs on the southern watershed to keep the aggressive Uma' Laran and associated Kenyah in check, and also to watch over the caves in the Seturan area. Although the relationship between the Punan and the Merap has changed significantly in recent decades, many Punan Malinau remain subservient to the Merap (and others), and in this respect they differ significantly from the Punan Tubu. It should be mentioned, too, that there have also been relations between the Kenyah of the Bahau and the Punan of the uppermost Malinau. Regarding bride price, the Punan Malinau have only recently begun to demand a price for their daughters. This was uncommon in the past. Some groups - such as Punan Halanga - do ask for a bride payment, but the price is usually not particularly high. The Punan Malinau have always buried their dead immediately and they did not practice secondary burial in the past. It is probable that the bury-and-run practice has been the most prevalent among the majority of Punan groups. Although the Punan Malinau are closely related to the Punan groups of the Tubu, they are less intermixed with groups of non-Punan. 


\section{An Ethnic SKetch}

\section{Punan Berusu'}

These Punan have been affiliated to the Berusu' (hence their name) for a long time, most likely already at the time when the Berusu' were still living in the upper Tubu and along the Malinau River. Today the Punan Berusu' are to be found in Bengalun (pop. 94 in 1989 and 97 in 1990), upper Gong Solok (pop. 66 in 1989, and 241 in 1990), ${ }^{3}$ and in Sekatak (pop. unknown). Their language is close to the language of the Punan Malinau, but it is heavily influenced by the Berusu' language. As bird nest collectors and guardians of bird nest caves, they have also been clients to the Tidung and the petty kingdoms of lower Malinau and Sesayap. This kind of strongly asymmetrical relationship is probably an important reason why these Punan are much less outspoken than Punan Tubu, and at least as subservient, if not more so, as the Punan of the upper Malinau. 


\title{
Punan Settlements and Subsistence in Upper Malinau
}

\begin{abstract}
T $\mathrm{n}$ this chapter I will present information about those groups of Punan -who have not resettled downriver and who are still living in smaller hamlets in upper Malinau or along the Hong or Ran rivers. Besides these groups, there are also five Punan settlements in the Tubu that have not resettled downriver. These Punan settlements have not been included in the brief presentation that follows. This chapter also contain a general sketch of Punan Malinau subsistence. Readers interested in reading more on Punan Malinau subsistence and resource use are referred to Levang (2002) and Puri (2001).
\end{abstract}

\section{I PUNAN VILLAGES IN UPPER MALINAU}

At least 120 Punan families - probably more - were living in the upper Malinau, above Tanjung Nanga (in February 2000). That would amount to at least 500 people. This can be compared to Padan \& Laway (1999), who state that there are 171 families and a total upriver Punan population of 682 souls (see Appendix 1). There are, in addition, approximately 40 45 Punan households along the Ran and Hong rivers (at least 200 individuals). None of these 700-900 Punan has resettled downstream. ${ }^{4}$ 
Punan Settlements and Subsistence in Upper Malinau

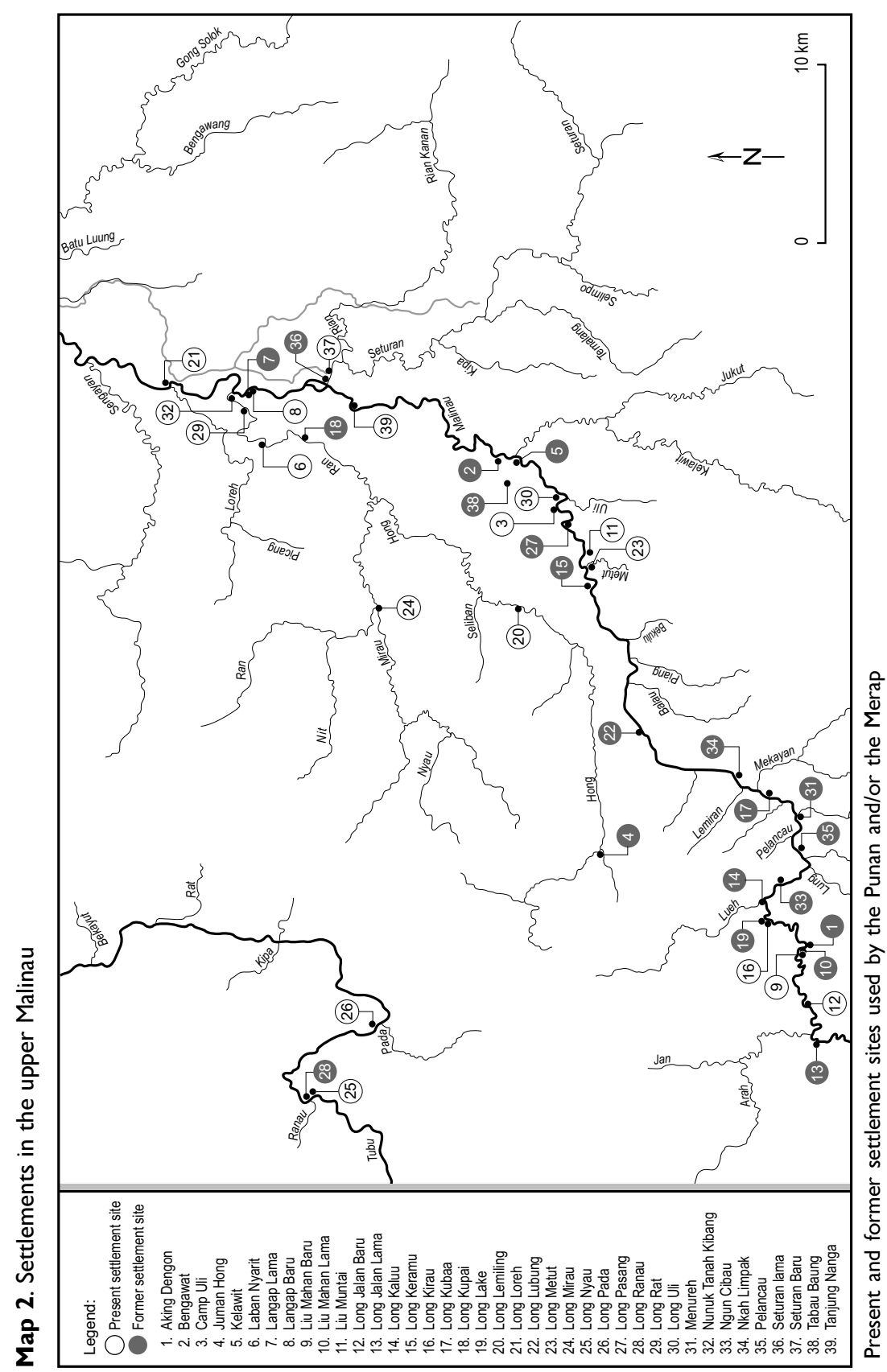




\section{Punan Settlements and Subsistence in Upper Malinau}

Table 3. Number of houses and households in upper Malinau, February 2000

\begin{tabular}{llcc}
\hline Settlement/Hamlet & Punan Group & No. of Houses & No. of Households \\
\hline Long Uli & P. Metut & 22 & 22 \\
Camp & P. Pelancau/Metut & 7 & 11 \\
Liu Mutai & P. Pelancau & 9 & 15 \\
Long Metut & P. Pelancau & 11 & 15 \\
Long Kirau & P. L. Lake & 17 & 35 \\
Long Jalan & P. L. Jalan (Arah) & 20 & 34 \\
& & 86 & 132
\end{tabular}

Houses owned/occupied by non-locals (e.g., traders, church representatives) are not included. The total number of families may not be exactly 132 , as indicated above, but lies in the interval between 125-135.

There are no schools and no health service available in the upper Malinau. Therefore very few children in these upriver settlements attend school. The only exceptions are Long Uli, where approximately 10 children attended school downriver in 2000, and Punan Halanga and Punan Mirau, where an unknown number of children attend school in Laban Nyarit. This lack of education and health facilities is seen by the local Punan as a major problem (see also Section 6.1).

\section{I.I. Punan Halanga}

The Punan Halanga is a rather large group of Punan Tubu who have been living as a number of small groups / bands along the upper reaches of the Ran River since the 1960s. Before moving to the Ran River they lived on the Halanga River in upper Tubu - hence their present ethnonym. They have probably lived along the Halanga River at least since the 1920s. Before that they probably lived at various locations along the Tubu River. There is an old durian tree, probably 100-150 years old, at Long Bunuh, downstream from the Bila' River, that was planted by a Punan called Utan Pilak, a man whose descendants are found among the Punan Halanga today, according to Bare' Tangga'. ${ }^{5}$

In 1990 there were, according to government data, 130 Punan Halanga (19 households). The real figure was probably higher than that. These Punan had already been officially resettled to Laban Nyarit in 1990, but there was still, in February 2000, only one household that had actually settled in this lokasi (location). As in 1990, the Punan Halanga 


\section{Punan Settlements and Subsistence in Upper Malinau}

in February 2000 still preferred to live at their swidden field huts. Whereas most of them had their huts along the upper reaches of the Ran River and along the Mirau River in 1990, most of them were now living in Kuala Mirau (12 households), along the logging road close to the Ran River, or along the Hong River.

I have no population figures for 1999, but there were, in February 2000, 12 Punan Halanga households in Kuala Mirau, and at least as many households who at that time were hunting and collecting (mufut, B.P. $)^{6}$ around the Hong River - most of them probably along the Seliban River.

\section{I.2. Punan Mirau}

The Punan Mirau are said to be the original inhabitants of the Ran River. As opposed to the other groups living along the Ran and Hong rivers today, Punan Mirau did not enter the area from Tubu or upper Malinau, at least not during the last 150 years. They got their name from a tributary stream of the Ran River, which is called the Mirau River. These Punan have a resettlement village at Laban Nyarit, although most of them never stay there. In February 2000 all of them were staying at their swidden field huts, situated along the Ran River between Laban Nyarit and Kuala Mirau. Two households also had a hut at Kuala Mirau.

In 1990 there were, according to Government data, 74 people belonging to this village ( 17 households).

\section{I.3. Punan Long Rat (Hangrat)}

The Punan Long Rat (or Punan Hangrat) came to the Ran River from the Rat River in upper Tubu at the beginning of the 1970s. They numbered 94 in 1990, when all of them were still living at their swidden fields along the lower part of the Ran River, even though they already had a village with houses made of planks at Kuala Ran at this time. They did not start living in this village before the local trader provided them with TV and a satellite disc (on credit) in 1995-6. 


\section{Punan Settlements and Subsistence in Upper Malinau}

In 1990 there were, according to government data, 94 people belonging to this village (19 households).

\section{I.4. Punan Metut}

The Punan who are called Punan Metut, or Punan Metut yang asli (Indonesian, the original Punan Metut), settled at Long Metut in the 1920s, when they were ordered by the Dutch to build a 'proper' village and settle there. These Punan, the original inhabitants of Metut, are today living farther downstream, in Long Uli and in the resettlement village of Seturan. A few details are known about their history, prior to their settlement in Long Metut some 70 years ago.

It is stated that a number of Punan from Kalun (Tubu) joined the Merap at the beginning of the $19^{\text {th }}$ century from Tubu to the upper Malinau. Several names are mentioned, such as Impang Jalee and Toh Ilau, both of whom with descendants among the Punan Metut today. It seems likely that Punan Metut - if not all of them - arrived at the Malinau River 180200 years ago at the initiative of the Merap. Some Punan Metut were probably also asked to move to the Rian River, Seturan, to watch the bird nest caves. Later, maybe during the 1920s or 1930s, a number of Punan from Menabur (or Kalun) in Tubu joined them and settled along the Rian River, Seturan.

At the end of the 1940s Punan Metut moved to Long Keramu; in 1960 to Long Pasang; in 1969 to Bengawat; and around 1985 they split in two, one group moving to Long Uli and the other group moving with the kepala desa, or headman, to lokasi Seturan.

According to government data, there were 140 Punan Metut in 1990 (35 households). According to my own data, there were 54 people living in Long Uli in 1992 (15 households) and an additional, unknown number of households living at their swidden fields in the vicinity of Long Uli. Padan \& Laway (1999) state that there were 32 households and 119 individuals in Long Uli in 1999. During my revisit in February 2000, there were 22 houses (at least 22 households) in Long Uli and 3 households at the timber camp just upstream from Long Uli. I do not know the actual number of Punan Metut living in Seturan. 


\section{Punan Settlements and Subsistence in Upper Malinau}

The village of Long Uli is composed of 24 houses, most of them built of planks. All of these houses have been built with money provided by the collection and trade in eaglewood. ${ }^{7}$

\section{I.5. Punan Pelancau}

The Punan Pelancau are known by this name because they settled at Pelancau in the upper Malinau in the 1920s, i.e., at the time when all the Punan in the upper Malinau were instructed by the Dutch to settle in 'proper' villages. Until then most of them were nomadic and probably moved around in the forests between the Malinau and Hong rivers. At least some of the Punan Pelancau trace their origin to the Menabur River in the Tubu area. They moved to Bengawat in 1971. They even had a school there at that time. From Bengawat half of them moved to Nkah Limpak, and half of them resettled downriver in Long Loreh in 1982.

In 1990, according to government data, there were 155 Punan Pelancau ( 16 households). Although all Punan Pelancau had been officially resettled to the resettlement village of Long Loreh, many of them were living farther upstream.

In 1992 there were approximately 10 households ( 8 houses) in Long Metut, 2 households in Nkah Aki', 5 households along the Bekulu' River, and at least 5-6 households in Nkah Limpak. That gives a figure of approximately 23 households in 4 locations upstream, and an additional number of resettled households in Long Loreh.

According to Padan \& Laway (1999), there were 35 individuals (8 households) in Long Metut in 1999, and an additional 151 individuals (43 households) in Long Keramu.

In February 2000, according to my own survey, there were 8 Punan Pelancau households in the timber camp at Long Uli and probably 12 families (8 houses) in Liu Mutai. Most of these households moved from Nkah Limpak to Long Keramu in 1994, and from Long Keramu to their present locations after floods in February 1999. In addition, there were 15 households in Long Metut. This gives a figure of 35 Punan Pelancau households in 3 locations upstream, in addition to those who have resettled in Long Loreh. 


\section{Punan Settlements and Subsistence in Upper Malinau}

\section{I.6. Punan Lake}

Punan Lake is the name of those Punan who settled in Long Lake in the 1920s at the initiative of the Dutch colonial administration. At the same time, other groups settled at Pelancau and Metut, groups who have since been known as Punan Pelancau and Punan Metut respectively.

Punan Lake mixed with Punan Beketan in the 1880-1890s. One Punan Beketan is particularly mentioned, Maring, whose sons became the leaders of various local Punan groups. One of them, Oyang, became headman of the Punan Liu Mahan. This group got this name after settling at Liu Mahan in the late 1940s and later resettled to Loreh, where they mixed with the Kenyah. Two other sons, La'ing and Atung, settled at Long Lake, while a fourth son, Ipu' Maring, went upstream in the late 1940s to the Arah River, probably because he didn't have any followers. He therefore joined the Punan Arah, i.e., the Punan living along the Arah River. Ipu Maring and the Punan Arah are today living in Long Jalan and are thus not classified as Punan Lake.

In 1990, according to statistics from the district office in Kota Malinau, there were 217 Punan Lake (34 households). Some of them were living in the resettlement village of Seturan, others were living upstream. In 1992, when I visited the upper Malinau, there were no settlements in either Long Lake or Long Kirau. The people now living in Long Kirau lived at Liu Mahan at that time (approx. 10 households) and along the Lue River (approx. 6 households), the Piang River, and in Juman Hong on the Hong River (approx. 5 households). At that time most households spent much more time in the forest and it was difficult to get accurate population figures. In 1992 there was also a group of 30 Punan Lake living along the Lemiling River on the lower part of the Hong River.

Padan \& Laway (1999) state that there were 23 households (115 individuals) in Long Lake and 20 households ( 83 individuals) in Long Kirau in 1999. According to my own survey in February 2000 there were 16 houses (probably as many as 20 households) in Long Kirau. In addition, there were probably as many as 15 households living along the Lake and Lue rivers, two tributaries of the Malinau River just downstream of Long Kirau. Many of these households, who have their swiddens and cassava 


\section{Punan Settlements and Subsistence in Upper Malinau}

gardens along the Lake and Lue rivers, probably spend much time in the forest. This was more common among many Punan groups 10 years ago, but today it seems as if only Punan Halanga, some Punan Mirau, as well as these, possibly, 15 Punan Lake households, still regularly enter the forest as groups of whole families. As there was an epidemic of dysentery in Long Kirau in February 2000, it might also be the case that more families than usual chose to spend a longer time in the forest, in order to avoid the epidemic. In February 2000 there were no Punan living along the upper Hong River anymore, but the smaller group that lived on the lower Hong was still living there. Even though this group is Punan Lake, they are administered under the village of Laban Nyarit.

\section{I.7. Punan Long Jalan/Punan Arah}

The majority of the people in Long Jalan are, by origin, Punan Arah. Actually, 27 households (18 houses) were classified as being the descendants of Punan Arah, while 7 households (2 houses) were said to be descendants of Punan Beketan.

There were in 1990, according to government data, 127 Punan Long Jalan (29 households). In 1992 there were 4 houses in Long Jalan (or actually in Nkah Bulu). Most households were at that time living at their gardens and small swiddens along the upper Malinau River.

According to Padan \& Laway (1999), there were 45 households and 179 individuals living in Long Jalan in 1999. My own survey in February 2000 found that there were 20 houses in Long Jalan, inhabited by 34 households. In addition, there were approximately 8 households living in lokasi Punan in Tanjung Nanga.

\subsection{PUNAN MALINAU SUBSISTENCE}

The Punan Malinau gain their livelihood from a combination of basically forest-oriented activities, such as hunting and gathering, collection of and trade in NTFPs, small-scale horticulture, rice cultivation, and by acting as porters and guides to anyone in need of their services. In addition, 
individuals may engage in wage labour, for shorter or longer periods of time, or devote time to the cultivation of cash crops. Their economy is truly versatile and shows much flexibility and adaptability to changing circumstances. In the last decade, however, the collection of eaglewood has been of such significance that other economic activities often have appeared to be of secondary and supplementary importance only. Hoffman has, in a controversial statement, suggested that "it is trade ... that has been what these 'Punan' of Borneo are all about" (1984: 164). Although this is not generally the case (Brosius 1988; Sellato 1988), it still has some relevance when considering certain groups of Punan during certain periods of time. The Punan Malinau, especially those living farther upstream, are today not primarily agriculturalists, horticulturalists, or even hunter-gatherers, but rather professional rainforest collectors.

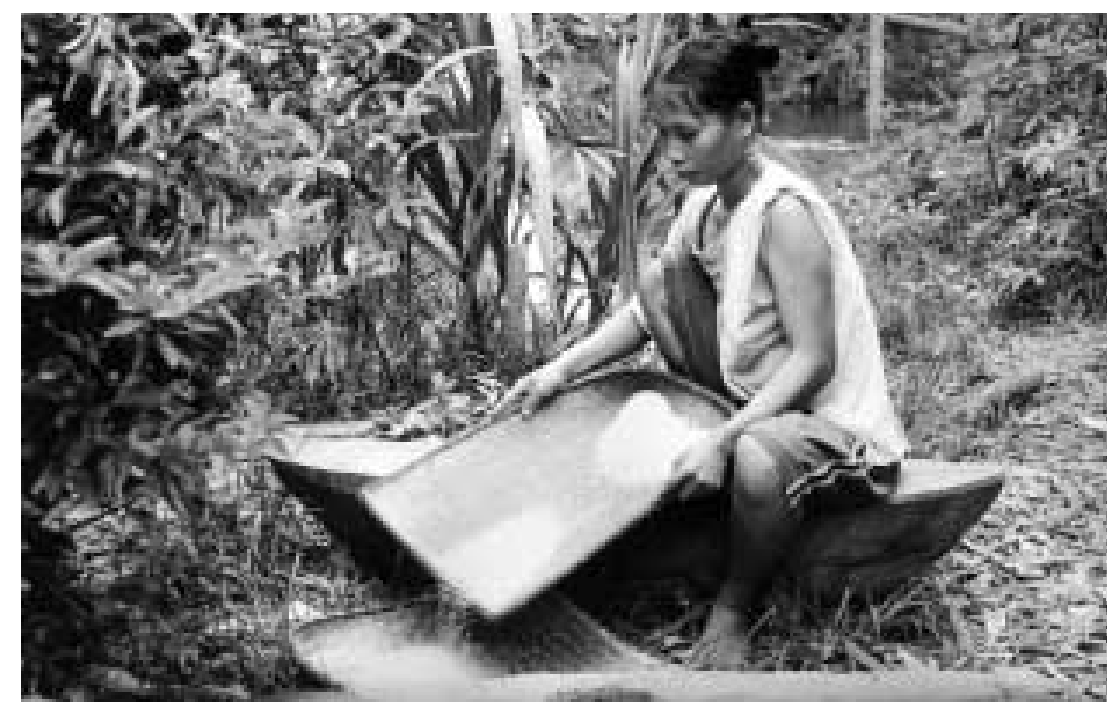

Rice must be winnowed, Metut, upper Malinau

\subsection{Agriculture}

Most of the carbohydrates consumed by the Punan today come from cultivated crops such as rice and cassava, which they have grown themselves. Traditionally their staple food was starch from several species 


\section{Punan Settlements and Subsistence in Upper Malinau}

of (wild) sago palms. Individual households among certain groups of Punan (e.g., Punan Lake and Punan Halanga), still occasionally extract sago. Although most Punan grow at least some rice, the yield from the harvest is usually not sufficient for more than a few months. The most important crop is cassava, several varieties of which are grown. Unlike rice, cassava can be harvested at any time of the year and therefore interferes little with other activities.

The Punan of the upper Malinau have small swidden fields where they grow rice. Individual households seldom plant more than one hectare with rice each year. This is also why the yield from the rice harvest is usually not sufficient for more than a few months. When other sources of income are available - in particular when eaglewood fetches a good price - some families may not open up new swiddens at all, while others plant only half a hectare of rice or less. On the other hand, individual households might, in certain years, plant up to two hectares of rice, although that is rare. Sellato states that, among Punan groups generally, 'swidden fields are often very small and poorly cared for' (1994: 181), and that 'farming is in direct competition with commercial collecting' (ibid.). This is certainly true for the Punan Malinau.

The reason why all these upriver Punan groups make such small swidden fields and why they even bother when the harvest is usually very small is probably because the women can attend the fields, as they spend most of their time in the settlements. According to Sellato, 'a wife may mind small swidden fields while her husband ranges the forest seeking products for the market' (1994: 181). As the price for eaglewood has been very high during the last ten years, men tend to spend more time in the forest collecting this resource. Even though women do agricultural work, their husbands and adult sons are free to spend most of the time kuca' lelah (B.P., searching for eaglewood).

\subsubsection{Wild food resources}

Gathering. In 1990-92 sago was sporadically processed and eaten by individual households in the upper Malinau, as well as those along the Hong and Ran rivers. There are three species of wild sago palms that 


\section{Punan Settlements and Subsistence in Upper Malinau}

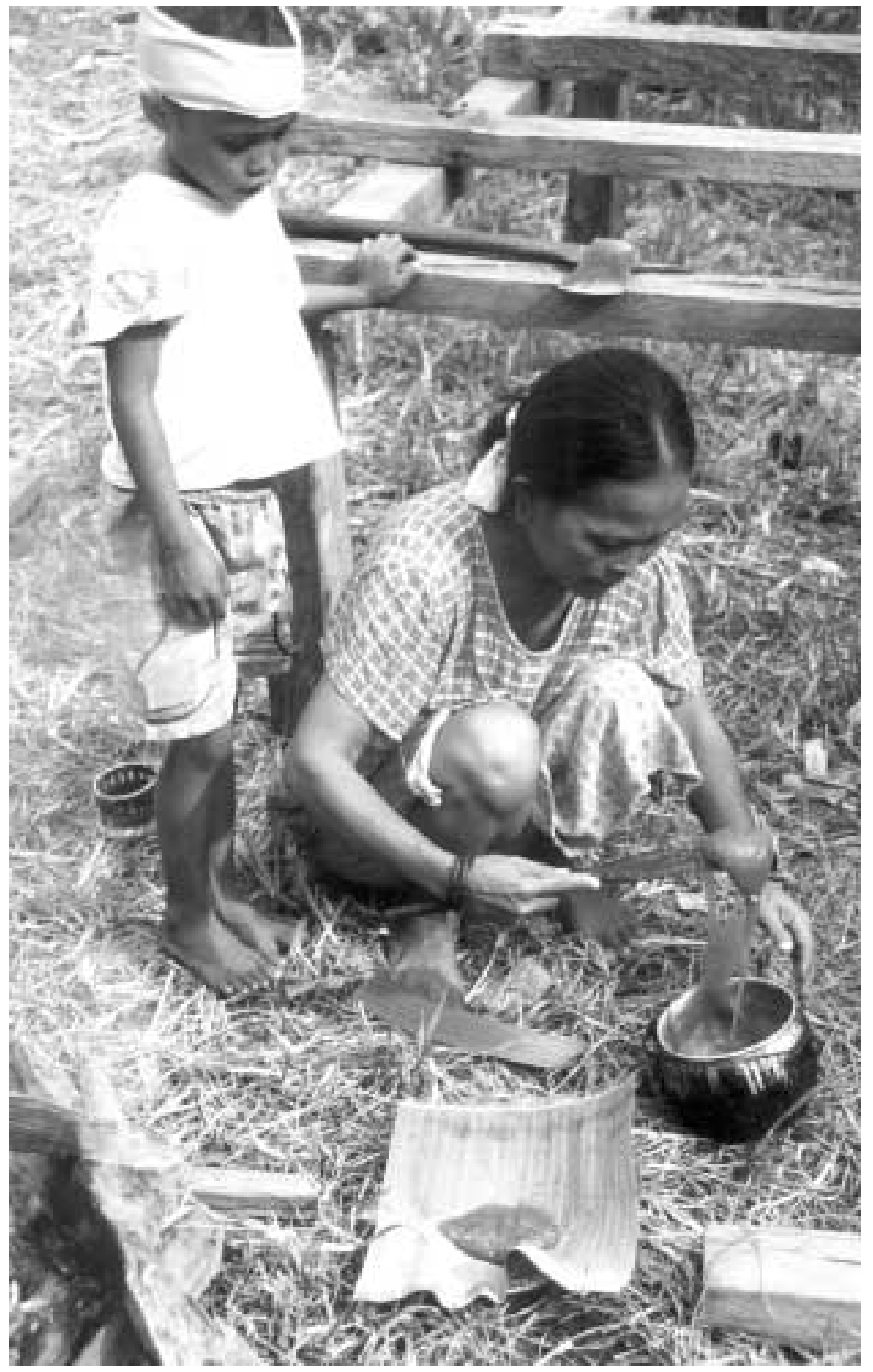

Sago, the Punans' traditional staple food, still complements rice and cassava 


\section{Punan Settlements and Subsistence in Upper Malinau}

may be utilized, according to the Punan Malinau. One of them, lelih (Caryota mitis) is usually avoided. Even though it tastes good, it causes diarrhoea and is troublesome to process (causes itching). Therefore, jemaa (Arenga undulatifolia) and fulung (Eugeissona utilis) are considered better alternatives, especially as they also taste better. The most frequently utilized of these are the fulung.

Punan are familiar with a very wide variety of wild plants, which are occasionally gathered by both women and men. These include bamboo, ferns, mushrooms, bananas, and rattan species. However, even if this is the case, they normally eat rather few wild vegetables, and not particularly frequently, and most of the carbohydrates consumed are grown by them or are taken as provisions from local traders. There is, in this case, a surprising discrepancy between botanical knowledge and actual practice. The indifference shown towards these wild food resources stands in sharp contrast to the elation exhibited by Punan during the fruit season, which is of exceptional importance, emotionally as well as nutritionally. Likewise, very few medicinal plants are used.

Peter Brosius was surprised to find that the Western Penan in Sarawak showed so little interest in medicinal plants in the 1980s, while they repeatedly talked about such plants ten years later (1997: 62). What is interesting in this case is not only the adoption by the Sarawak Penan of environmentalist rhetoric, but also the fact that there may be a discrepancy between the local ethno-biological knowledge as such, and the actual utilization of such resources. The reason why local Punan made such little use of wild vegetables during my field research in 199092 in the Malinau/Tubu area was not due to a lack of knowledge or a lack of such resources in the surrounding forests. The Punan are familiar with a wide variety of wild plants, but for various reasons these food items are not highly valued. The same phenomenon could be observed in relation to various cultivated resources, such as cassava leaves, a resource that is available in large quantities just outside any Punan house / hut upriver. Although people claim to like the taste of cassava, ferns, or bamboo shoots, they do not expend much energy collecting them. These items, although very common, are not highly priced foodstuffs. 
Hunting and Fishing. Although many kinds of wild animals are hunted and eaten, wild boar and deer are the meats most consumed by the Punan. The meat of these larger animals is avidly sought and has exceptional symbolic value. These animals are usually killed by spear and with the assistance of hunting dogs, ${ }^{8}$ while most other game animals are killed using a blowpipe. Besides the bearded pig and the different species of deer, there are a number of species that are considered tasty and delicious: various monkeys, binturong, mongoose, Malay sun bear, various civets/palm civets, linsang, forest cats, porcupine, various squirrels, giant squirrel, colugo, and pangolin. Among reptiles, python meat and the water monitor are appreciated. Turtles/tortoises are also eaten, although not ranked among the most delicious kinds of meat. Larger birds are also considered nice to eat, such as hornbills or pheasants. Not all animal species, however, are considered tasty. Species that my informants did not like to eat were otter, moon rat, tree shrews, king cobra, and most other snake species (except the python), and — although absent in the forests upriver - the proboscis monkey. While frogs were eaten in some settlements, they were not regarded as a food resource in others. Birds of prey do not seem to be eaten by any Punan in the Malinau area.

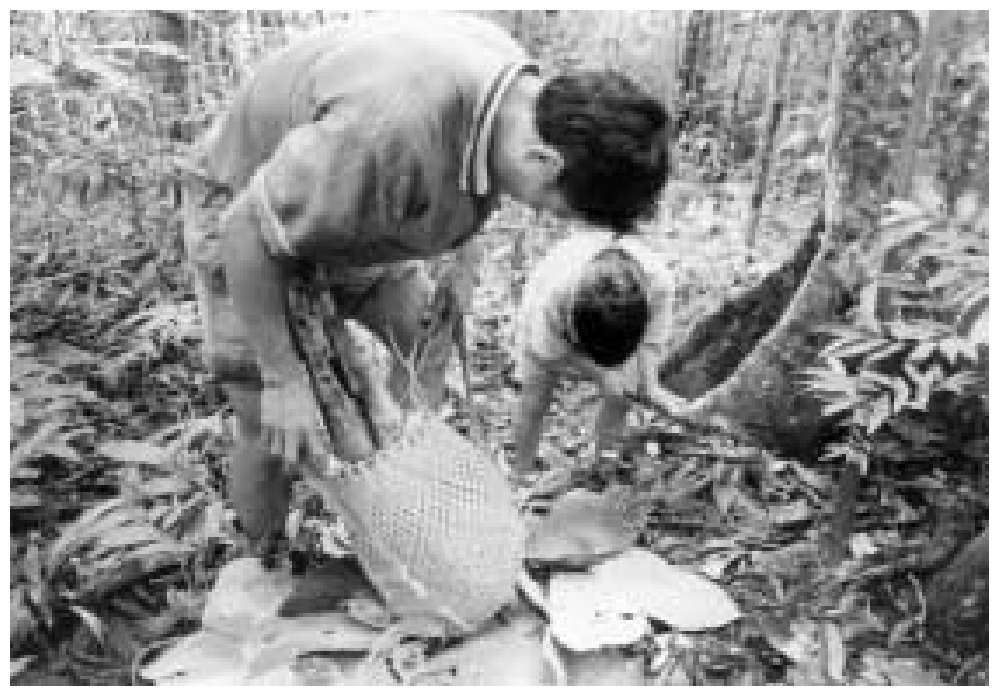

Returning from the hunt in the upper Tubu 


\section{Punan Settlements and Subsistence in Upper Malinau}

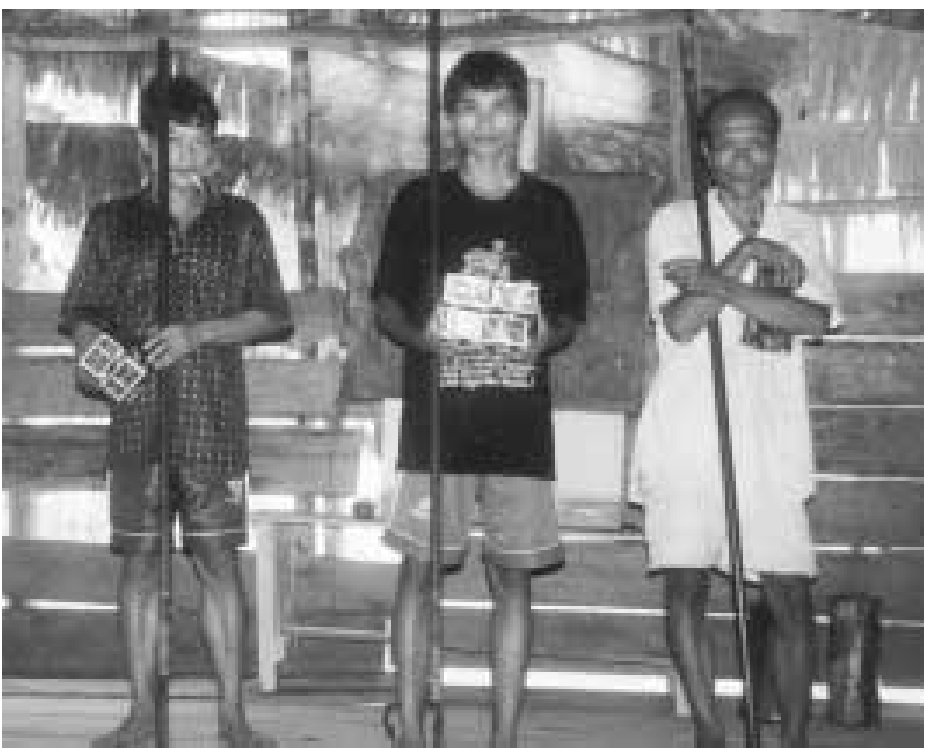

The Punan are reknowned blowpipe hunters (Laureates of the Long Jalan 2000 blowpipe contest)

Another interesting question is how the utilization of faunal resources are restricted or directed because of ideological reasons, such as religious considerations, taboos, and prohibitions. Although animals have played a very significant role in local religious beliefs and cosmologies, few of these beliefs restricted the actual killing of individual species. Certain bird and mammal species were seen as messengers from a spiritual world — as among all other indigenous peoples of Central Borneo - giving advice on when to engage in or avoid certain activities. There is also, among the Punan Malinau and many other indigenous peoples in Borneo, a system of beliefs concerning the mockery of animals (cf. Needham 1964). According to this belief, the joking or laughing at certain animals - especially leaf monkeys and frogs — is connected to extreme spiritual danger. People had no reason to refrain from hunting or killing such animals, but they had to avoid certain behaviours when handling them. The spiritual danger associated with the leaf monkey is also a reason why this animal is referred to by two different names, oilaih and eceu. In the presence of a leaf monkey, depending on whether it was alive in the surrounding trees or dead beside the hunter, the Punan avoided the word eceu and instead talked about aih (or oi). 


\section{Punan Settlements and Subsistence in Upper Malinau}

There are rather few food taboos (B.P., kun tenggih), and there is little consistency on this point among the various Punan groups. While the king cobra seems to be avoided by all groups, the bear is eaten by some and not by others. Certain species are generally considered dangerous or inappropriate for women, including such species as the python, the clouded leopard, the bear, the pig-tailed and long-tailed macaques, and the rhinoceros hornbill. However, the only occasion surrounded by a number of taboos, including food taboos, is pregnancy. During pregnancy, the future parents have to observe a number of prohibitions and taboos. They cannot eat certain animals, such as frogs, turtles, or pangolin.

Among many groups of Punan, aquatic resources are often the most important everyday source of animal protein. Especially in the sparsely populated upriver areas, there is abundance of fish, and for most of the year fish and other aquatic resources, including reptiles and amphibians, are the most reliable food resource. There is, however, much local variation on this point.

\subsubsection{Wage labour and cash crops}

Wage labour is of minor importance, partly because local companies recruit few people locally, and partly because the Punan consider the wages they are generally paid to be too low. Individual Punan who have worked in the timber industry in Sarawak have earned substantial incomes, however, and they have sometimes worked there for periods of several years. Cash crops, such as cacao and coffee, are considered to be potential alternatives for earning cash, especially among the Punan living closer to the market. In 1990-92 there were, however, few incentives for the cultivation of cash crops, mainly because of the rapidly rising price of eaglewood. Today the situation has changed and, especially in the area surrounding Long Loreh and the mining company, there are new incentives to plant cash crops, besides the cash that can be earned by selling the crop. Establishing a cash crop plantation is a way of claiming the land and, in a way, turning it into personal property. If this land is later of interest to local companies, the 'owner' of the land can expect to be compensated. 


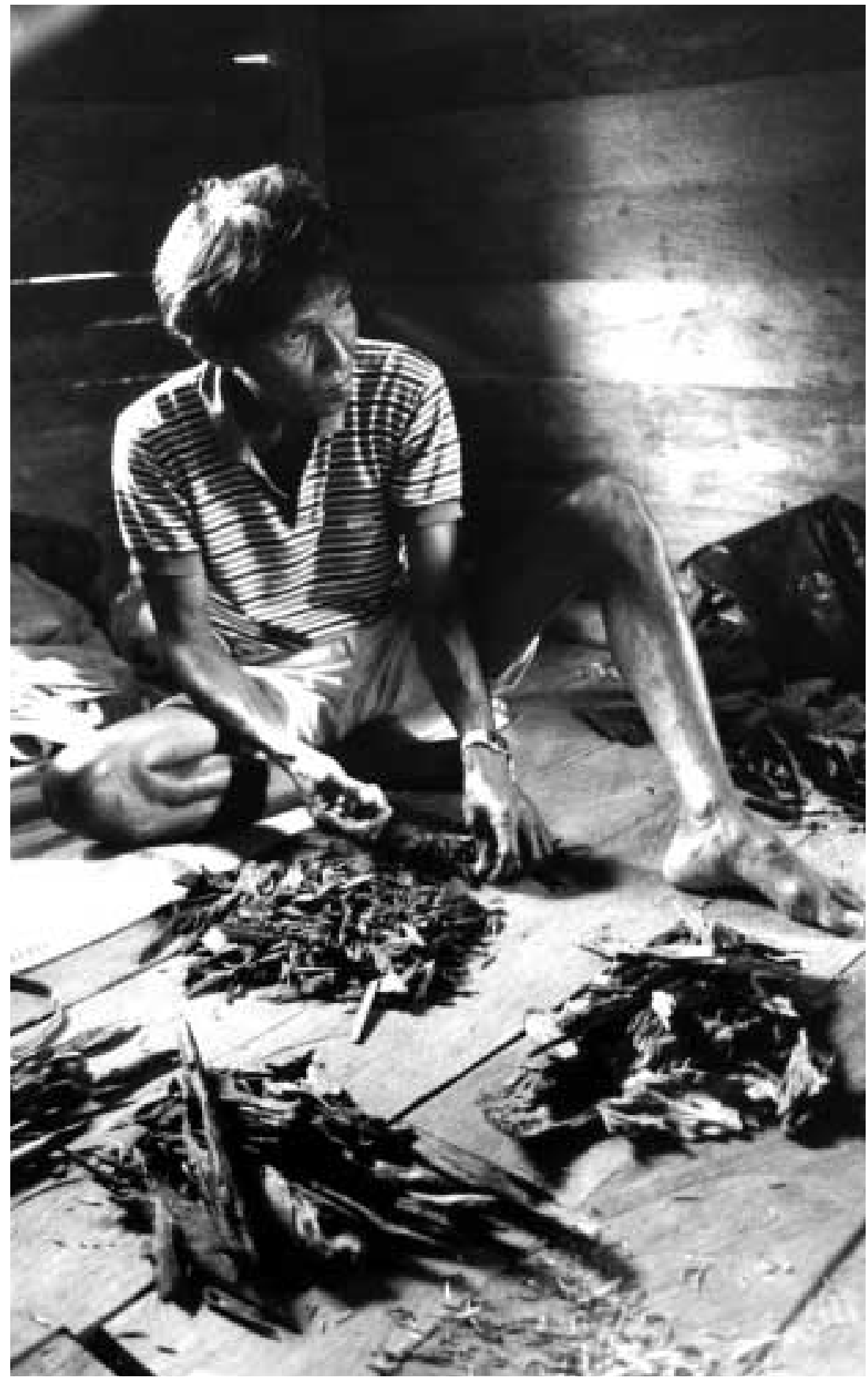

The main means of income for the Punan is collecting and selling gaharu (eaglewood) 


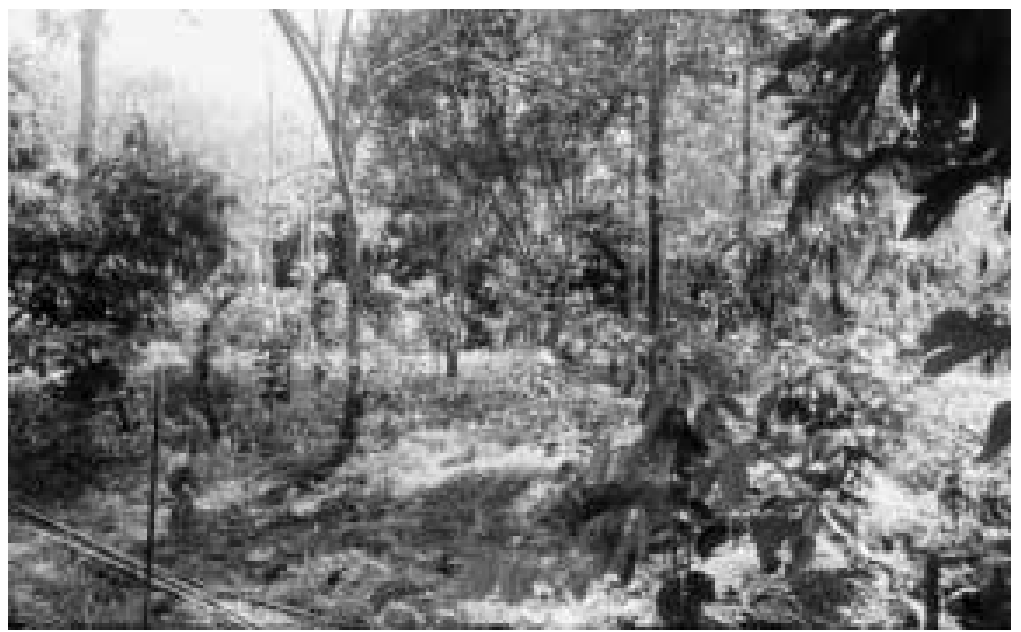

Cocoa and coffee are considered as potential alternatives for earning cash

\subsubsection{Non-Timber Forest Products and Trade/NTFPs}

The collection and sale of such NTFPs as rattan, various resins, and eaglewood have long been of vital importance to the Punan economy (cf. De Beer \& MacDermott 1989; Katz 1997). At the end of the 1980s, the demand for eaglewood increased, with high-quality eaglewood fetching approximately US\$ $\$ 50-100$ per kilo. The price rose to about US $\$ 300$ per kilo in 1991-92. By 1999, the price had risen to as much as US\$ 700 per kilo (Wollenberg 1999).

In Punan Malinau subsistence, priority is given to the collection of commercially valuable NTFPs. For the last 10 years, however, there has only been one product that has had a good price on the market, and that is eaglewood. Illipe nuts ${ }^{9}$ also have a good price, but this resource is available only certain years and is therefore only an occasional income source. In most settlements all able men spend between 1-4 weeks in the forest each month of the year in order to collect eaglewood. There is not necessarily any major difference regarding how much time the men of various settlements spend looking for eaglewood. There's variation in all settlements, where some individuals spend more time and longer periods in the forest than others. 


\section{Punan Settlements and Subsistence in Upper Malinau}

Eaglewood has thus been the economically most important NTFP for Punans in recent years. It is collected by small groups of men, perhaps a father and his sons, or by larger parties, organized and financed by a local trader. In a system based on credit, called utang or bon, traders offer members of these parties provisions on account. This practice both enables the collectors to spend longer periods in the forest and allows the trader to 'monopolize' their labour in relation to other traders. In this way, traders do not control or compete among each other for particular areas; what they do try to control is a certain number of clients.

The credit that various families have received is seldom ever paid off. They are continuously in debt, which means that traders, by various means, try to induce their clients to go looking for eaglewood. In cases where a family receives an income from another source, traders are usually present to try to retrieve some of these resources as payments for the credits they had given earlier. In some cases traders confiscate things given to a community by the government, such as plates of tin roofs, as partial payments of debts. Although a few men may occasionally sell some of their eaglewood to traders downriver, such as in Malinau, this is very uncommon. People upstream on the Malinau River usually lack the means of transportation and most of them are in debt to their local traders, who keep an eye on their movements in order not to be bypassed.

In all villages upstream there is at least one, sometimes several, traders present most of the time. Many of these traders have built their own houses in the middle of these local communities, making it more difficult for the Punan to bypass them. Some goods are so expensive that the Punan can seldom if ever afford to buy them. This is the case when it comes to building a house (which could cost up to 10 million rupiah or more), buying a long-tail engine, etc. The buying of these products necessitates some kind of foresight and planning. Some Punan may actually buy more and more planks, until they have enough to build a whole house, but often the building of a house involves some kind of credit. The same is true for boat engines. The only new long-tail engines I saw upriver, in February 2000, owned by local Punan, were given on credit by the local trader. The price for a five hp engine was 2.5 million rupiah at that time. 


\section{Punan Settlements and Subsistence in Upper Malinau}

\subsubsection{The role of women}

Research focused on NTFPs and people is usually directed towards the activities and perspectives of men, as it is mainly men who do the actual collection and trade in NTFPs. However, the role of women is just as important, if not in the actual collection, then in the overall economy of the Punan Malinau. Women, too, are responsible for perhaps as much as two-thirds of all agricultural work. The responsibility for the growing of various crops, such as cassava, rice, etc., is particularly in the hands of women. The weaving of rattan mats and baskets is the exclusive work of women. Most of these activities are done within the boundaries of the small settlements, which means that women are much more bound to the hamlets, the settlements.

The Punan economy is by no way dominated by agriculture, although the importance of agriculture differs through time and by households. Nicolaisen (1986) says that among the Kajang in Sarawak, the fact that women do most of the agricultural work 'impedes agricultural growth', as 'with a growing demand on female labour in the immediate domestic sphere, agricultural productivity is affected' (1986: 100). When the number of children who attend school downriver increases, there are fewer daughters who can assist their mothers in taking care of the smaller children, doing household work, etc. The workload on women increases. All this is of great importance when studying the importance of NTFPs in local economies and subsistence. 


\section{An Ethno-historic Sketch}

\section{I. WHOSE HISTORY?}

The ethno-historic sketch presented in this chapter cannot claim to be an objective description of the'real' history. It is just as subjective as any other description of the local history. The construction of history is always selective and ideological, and it is therefore increasingly referred to as an historical narrative. It is often stressed that history is more a product of present needs than a description of something past (cf. Hylland Eriksen 1997). The compilation of historical data presented here has been informed within an anthropological and scientific context, where certain questions are considered more relevant or worthwhile than others. Within a local context, however, historical data has become increasingly important for political reasons, not least those relating to land and natural resources.

Bare' Tangga', an old and knowledgeable Punan Tubu man, has on several occasions pointed out the importance of recording historical data in detail and of making this data locally available. Collecting this data and then bringing it out of the local context to faraway places like Jakarta or western cities, is of no help at all to the local people. So, he asks himself, why should this historical data be considered more important to scientists and other categories of outsiders? It is not their history. The collection of ethnographic and historical data by various outsiders can, 
according to Bare' Tangga', be seen as part of their way of making a living, of earning money and prestige and of making a career. Bare' Tangga' does not resent this, but he feels that the interests of the local people should be respected and all documents based on local oral tradition should be made available locally. It is, after all, their history. It is, in addition, they — like Bare' Tangga' himself — who have memorized this history and it is they who have passed it down from generation to generation. The local people should, therefore, also retain the rights to their own history. As historical data has become increasingly important in the local people's struggle for land rights, Bare' Tangga' also emphasized that it is their future, not that of the outsiders, that is at stake now. In this way Bare' Tangga' also points out that the collection of ethno-historic data is also a question of what has been labelled intellectual property rights (cf. Posey \& Dutfield 1996).

\subsection{THE GROWING POLITICAL SIGNIFICANCE OF HISTORICAL DATA}

Punan, especially Punan Tubu, have increasingly realized the political importance of history. Punan leaders have always had some knowledge of their group's history and oral traditions, including genealogical data. Some leaders have even had an impressive command of such knowledge, but the majority of Punan have not paid much attention to history. Today, however, historical knowledge has become increasingly important, particularly in order to claim rights to land. Claiming, as Punan do, that they are the first inhabitants of the Malinau and Tubu areas is one thing; providing detailed and convincing narratives is just as important. Therefore, knowledgeable leaders can become very important in providing convincing arguments to legitimate land claims.

Punan Tubu generally state that the Punan are the original inhabitants of the Malinau and Tubu areas. All other groups are later arrivals. In 1990, however, they were much less interested in this particular question and they suggested that they had always lived in the Malinau-Tubu area. But they neither made a point of this, nor considered 


\section{AN ETHNO-HISTORIC SKETCH}

it to be particularly important. They just stated that they had no memories of living anywhere else. Today this has changed, and for good reason.

What seems to worry some of them - especially the Punan Tubu leaders - is the fact that the Punan have not left much trace in the surrounding landscape, as the Merap have. This, in a way, supports the Merap claim to the whole Malinau area. They can point out a large number of old village sites, from the headwaters of the Malinau River downriver. The Punan are, therefore, eager to point out that the lack of old Punan village sites does not mean that the Punan have not been present in the area for a long time. The reason is that the Punan have been nomadic, usually not living along the main river, but farther up small tributary streams or inland, often shifting their place of residence and normally residing in small huts.

The Punan are also increasingly aware of the powerful value of the written word, including its value for government institutions. There is thus among the Punan a need to create maps - as is being done in cooperation with CIFOR - and to put things into writing, in order to enhance their 'truth', and thus strengthen the legitimacy of the people's claims.

Despite this, the Punan claim of being the original inhabitants of the Malinau watershed is a problematic one. It is most likely that most of their ancestors arrived in Malinau from the Tubu and the Mentarang areas during the 19th century and that most of them arrived as followers of particular groups of Merap; or that they were asked to come there by the Merap. However, if we move even further back in time, more than 200-250 years ago (i.e., before the arrival of the Merap), it seems likely that both the Malinau and the Tubu areas were inhabited by Punan who at that time still had not differentiated in the way they have during the last two centuries (i.e., into Punan Tubu, Punan Malinau, Punan Berusu', and Punan Lejuh). I will return to this issue in section 4.6.5. below. My point here is just that their claim of being the original inhabitants of the Malinau area is most likely correct, although problematic. 


\subsection{EARLY INHABITANTS OF THE AREA}

\subsection{The Ngurik}

According to Schneeberger, the Ngurik (or Ngorik, Ngorek, Murik) are probably 'the original inhabitants of the Bahau area valley' (1979: 41). They have lived in the Bahau-Lurah-Pujungan area since at least the 17th century (Sellato 1995a). Those who lived on the Bahau River were generally known as Hweng Mbau (ibid.). The Ngurik also entered the Tubu area from the Bahau. However, not all of them identified themselves as Ngurik, nor did others identify them as such.

Between 1750 and 1850 the Uma' Laran and Uma' Apan (both Kayan), the Ga'ai (Modang) and their Kenyah allies repeatedly attacked the different groups of Ngurik living on the Pujungan and the Bahau rivers, enslaving them or chasing them away into other areas. The Merap left the Lurah for this reason and fled to the Malinau-Tubu area at the end of the 18th century. From the beginning of the 19th century, but particularly from 1850 onwards, different groups of Kenyah (Uma' Alim, Leppo' Ke, Leppo' Ma'ut) started to populate the Bahau area, while the Kayan and Modang moved farther downstream to the lower part of the Kayan River. This has been described in more detail by others (Sellato 1995a).

\subsubsection{The Berusu'}

If the various Ngurik groups are the original inhabitants of the Bahau, then the Berusu' can be considered to be (one of) the first inhabitants of the Malinau and Tubu areas, although all of them are living in Bengalun and Sekatak today. The Punan Tubu of today can point out several locations in upper Tubu (i.e., Long Lemunjung) with fruit trees planted by the Berusu' a long time ago. The same is true for the Malinau watershed. It is, therefore, somewhat surprising that the Punan themselves have no memory of any interaction with the Berusu' when they were living on the upper Tubu or the middle and upper Malinau. However, several informants suggest that the present-day Punan Bengalun and Punan Gong Solok lived on the Hong River and the upper Malinau in the 


\section{AN ETHNO-HISTORIC SKETCH}

past, as well as on the upper Tubu. It is therefore most likely that at least some of the Punan who lived in upper Tubu actually joined the Berusu' when they left the Tubu (to upper Malinau?), probably in the $18^{\text {th }}$ century.

According to the Berusu' themselves currently living in Bengalun, they once lived in upper Tubu, and on the middle and upper Malinau. This is also indicated by the Punan Bengalun, who refer to Tubu as their place of origin. They left the Tubu River and migrated to the upper Malinau River at approximately the same time as the Berusu' did. At this time according to the Punan in Bengalun - there were already groups of Punan living on the upper Malinau (Punan Arah?). According to the Berusu' genealogies, there are also plenty of references to the middle part of the Malinau River, especially six to seven generations ago. It was at this time that the Merap arrived, and Merap names do occur in their genealogies, something that indicates cases of intermarriage between the Merap and Berusu' at that time. It seems unlikely, however, that this was something common, as conflicts between the Merap and Berusu' were many - especially regarding caves containing bird nests.

According to the Punan Malinau, the Berusu' used to live in Malinau and Hong in the past, prior to the arrival of the Merap. All these Berusu' were driven away by the Merap, according to several Punan Malinau informants, although this is often denied by the Merap. Berusu', on the other hand, state that when they were living on the Malinau River, their main enemies were the Tenggelang from Sembakung and Abai from Mentarang, but not really the Merap. However, they also pointed out that they nevertheless had reason - in the past - to refrain from mixing with the Merap, as such mixing carried the 'smell of corpses' (B.I., bau busuk).

As indicated above, the Berusu' have left several traces in the landscape, in upper Tubu, but especially in upper Malinau. The Punan Malinau can point out several such locations - usually consisting of old fruit trees, such as along the Keliben River (Kelawit), along the Bengarui River (Seturan), or along the Bek River (Rian). There may even be - or at least have been - some traces of the Berusu' as far upstream as Nkah Limpak. 


\section{AN ETHNO-HISTORIC SKETCH}

Hence, around 1800, before the arrival of the Merap, there were Berusu' living in upper Tubu, in middle and upper Malinau, and probably along the Hong River. There were also Berusu' living in the Long Peso area on the Kayan River, before they were pushed away by the Kayan Uma' Laran and Kayan Uma' Apan (Sellato, pers. comm.). If there were any Punan in the Malinau area at that time, it is likely that it was Punan related to the Punan of present-day Sekatak and Bengalun; i.e., Punan groups affiliated to the Berusu'. Those Punan who are living on the upper Malinau River today probably arrived from other areas - such as Kalun and Menabur (Tubu) - sometime around the end of the $18^{\text {th }}$ century onwards, i.e., after the arrival of the Merap. An exception may be the Punan of the Arah River at the headwaters of the Malinau River. These Punan may previously have been affiliated to the Berusu', either those in the upper Tubu or those in the upper Malinau, or both. Those Punan who live in Long Jalan today are descendants of these Punan Arah.

\subsubsection{The arrival of the Merap}

The Merap entered the Malinau-Tubu area from the west, i.e., the Bahau. This is why they are also known as the Bau (or Bao) Dayaks and why the Punan used to call them wang Bau, i.e., the Bau or Bahau people. Most Merap informants suggest that their ethnonym, Merap, is derived from a river with that name in the upper Malinau, or in the Bahau. According to Sellato (pers. comm.), their autonym is Mbraa, and they possibly lived in the Beraa River area of the upper Bahau.

Some Punan in the Malinau-Tubu area refer to all Merap as 'orang Bau', while others make a very clear distinction between Merap and orang Bau (wang Bau, in Punan). For example, those in Langap are often classified as 'Merap', while other groups (such as those from Long Kendai) are classified as 'orang Bau', not Merap. Bare' Tangga', former headman of Bila' Bekayuk, ${ }^{10}$ makes this distinction. He also recalled a conversation he once had with an old man from Long Kubaa, ${ }^{11}$ who said to him that 'in the past we were Ngurik, not Merap. Now the language is the same and we're all Merap. In the past we were Bau, or Ngurik'. 


\section{AN ETHNO-HISTORIC SKETCH}

According to Bare' Tangga', a long time ago there was a group of orang Bau living at the headwaters of the Malinau River at the same time that orang Merap were living on the Merap River in the upper Malinau. These orang Bau were living on the Liu River, a tributary stream in the upper Malinau, and they therefore identified themselves as orang Liu. According to local oral history, there was a conflict between these two groups concerning a marriage agreement that was broken by the orang Liu and their refusal to pay a fine. This led to an open conflict, which caused the orang Liu to escape into the mountains. ${ }^{12}$ Repeated battles were fought, but the orang Liu always lost, and therefore finally left the area and instead settled in the upper Tubu. In time, the enmity between these groups came to an end. Today these orang Liu are to be found among the inhabitants of Long Kendai (a village resettled from the upper Tubu to Respen Sembuak and to Kuala Ran). They are therefore not Merap, but orang Bau. Bare' Tangga' also mentioned that they also have been known as wang Apan (literally, people of the mountaintops).

This interesting narrative gives further detail to the assumption that the present-day Merap have a rather diverse origin. I would suggest that the Merap derive from two or, more likely, several different groups. If not all, then at least some of these groups belong to the Ngurik category, i.e., the original inhabitants of the Bahau area. Therefore, the present-day Merap derive from 1) one group that came from the Lurah River via the Aran River to the upper Malinau (i.e., the 'Berap' above), and also 2) from one or several groups that came from the upper Bahau to the Tubu River.

When the group from the Lurah fled to the Kerayan because of Kayan Uma' Laran attacks and eventually came to Kalun in the Tubu before returning to the Malinau again - they probably joined forces with the upper Bahau group/s then living on the upper Tubu. Some of the latter people may have remained on the Tubu after the Merap returned to the Malinau area. It is also possible that (some of) these upper Bahau groups, which remained on the Tubu, were known or became known by other names, such as Ngurik, Berau, Saben, or Tembau (some of them perhaps mixing with Lun Daye-speaking groups on the upper Bahau). One Berau village was still in existence on the Kalun River 50 years ago (Cf . Schneeberger 1979). 


\section{AN ETHNO-HISTORIC SKETCH}

\subsubsection{The establishment of Merap dominance in the Malinau area}

The Merap claim to be the masters and rightful owners of the Malinau watershed, from the headwaters to as far downriver as the village of Gong Solok. This huge tract of land is considered to be their customary land. All the other ethnic groups - especially more recent arrivals, such as the Kenyah and Pua - only have use-rights. Even though Merap can present historical evidence that supports their custodianship - something they certainly do today - their chances in reality of pressing these claims are, however, minimal.

The Merap have, for the last 100-150 years, been the indisputable overlords of a large part of the Malinau watershed, including its major tributaries (e.g., Sengayan, Ran, Hong, Seturan), as well as parts of the Tubu area. This overlordship was successively established over the course of the $19^{\text {th }}$ century and probably reached its height - at least politically - during the first half of the $20^{\text {th }}$ century. From an economic point of view, the abolition of slavery by the Dutch in 1915-1920, as well as the increased competition from Chinese and Malay (Bugis) traders in the early 1900s, probably reduced some of the economic advantages of the Merap aristocracy, but this did not challenge or reduce the political strength of the Merap. However, beginning in the 1970s, but especially thereafter, this political dominance has successively been reduced and increasingly contested, especially by the well-organized and politically influential Kenyah groups, and lately also by a growing number of Punan - the Merap's former clients and anak buah. ${ }^{13}$

In the remaining part of this section, I will present some further detail on the ethno-history of the Merap,${ }^{14}$ focusing particular attention on the $19^{\text {th }}$ century and the Merap acquisition of control of the Malinau watershed. As has been mentioned earlier, the Merap entered the Malinau and Tubu at the end of the $18^{\text {th }}$ century. They left their previous haunts in the Bahau watershed as a result of warfare and threats from the expanding and militarily strong Kayan Uma' Laran and Kayan Uma' Apan. 


\subsection{THE ETHNO-HISTORY OFTHE LANGAP MERAP}

I will here present some detail on the ethno-history of one group of Merap, i.e., those presently living in Langap. These Merap can be said to have been the leading group of Merap, although not uncontested, whose leaders, during a large part of the $20^{\text {th }}$ century, held the position of a kind of paramount chief (kepala besar) in the Malinau and Tubu areas.

\section{Into a distant and mythical past}

The Merap - at least those of noble ancestry - trace their origin to a mythical past, when the earth was inhabited only by spiritual beings. In this distant past two eggs were presented that gave birth to a man, Neau Kincung (or Ncau Tincung) and a women, Dayang Angung (or Layang Gung). According to Merap oral history, this spiritual/divine couple gave birth to the first human being/s, or at least the first Merap of noble descent. This human being, Nyihan Ncau, and his - more or less - divine parents, are therefore the apical ancestors of the Merap. If Nyihan Ncau is considered to be the first human leader of the Merap, then Mpang Alang, the former headman in Langap, represents the $10^{\text {th }}$ generation. If this genealogy is correct, Nyihan Ncau must have been born in 1740 or earlier.

\section{$1750-1830$}

Nyihan Ncau had a son, Alang Nyihan, who may have lived on the lower Lurah in the Bahau area. According to Sellato (1995a), there were probably at this time two Merap (or Berap) villages on the lower Lurah, one at Gunung Makan (Kedayan River) and another one at Gunung Imbu (Belaka River). At this time, the latter half of the $18^{\text {th }}$ century, there were also other (Ngorek) groups settled in the Lurah, including Tembau, Pua', Nyibun, Murik, and perhaps Leppo' Kuda (ibid.).

Alang Nyihan had at least one son, Ncau Alang, who probably was born around 1770. He grew up in a time when groups of Kayan (Kayan Uma' Laran and Kayan Uma' Apan) and Modang (Ga'ai) were expanding into the Pujungan and Bahau areas from the Apo Kayan. 


\section{AN ETHNO-HISTORIC SKETCH}

According to Sellato (1995a), the Lurah and its Ngorek population were repeatedly attacked during the last decades of the $18^{\text {th }}$ century. A number of groups therefore left the area; some of them went to the Baram (early Murik), others went to the upper Bahau (Tembau), and the Merap (or Berap, or whatever they called themselves at that time) went to Malinau. It is likely that these Merap, with Chief Ncau Alang, left the Lurah in the company of one or several bands of local Punan. It is probable that they entered the Malinau via the Aran River. They may have lived on the Merap River at the headwaters of the Malinau River for some time. This may also be the origin of their ethnonym, Merap. This is in any case the opinion of the contemporary Punan in the upper Malinau.

Although there is no reason to doubt that the Merap had once been settled along the Merap River in the upper Malinau, it is unclear when this occurred. According to Sellato (1995a), the Merap from Lurah moved more or less directly to the upper Tubu, where they had a village at Long Turan (ibid.). Eventually, however, the Merap fled to the Mentarang River, where they got help from the Abai against the attacks of the Kayan Uma' Laran. They then moved farther upriver into the Kerayan and were settled for some time at Pa Upan. From there they went to the Kalun River, Tubu - maybe around 1820 (Sellato 1995a). This means that the time span between the escape from the Lurah River and the arrival at the Kalun River may encompass some 20-25 years.

The Merap settled at Redak Lalan in the Kalun, most likely a strategic location on a flat area in the mountains. Especially between 1750-1850, villages were often strategically located on hilltops. Several such hilltops were inhabited by a number of ethnic groups that joined forces in order to withstand attacks by enemy groups. The most important hilltops or mountains mentioned in local ethno-history are Tukuk Jerau, situated between the upper Tubu and Kalun; Tukuk Apa', on the upper Kalun; and Tukuk Nyurat, on the Arah River, upper Malinau. Rendak Lalan may have been such a multi-ethnic, strategically located village, where the Merap allied themselves to a growing number of local Punan bands and established close relations - including marriages - with the Abai/Tebilun and other local groups (Milau, Merau/Berau). When newly arrived in the Kalun, the Merap were involved in a conflict with the 


\section{AN ETHNO-HISTORIC SKETCH}

Tembau of the Kerayan. ${ }^{15}$ This conflict was, however, short and relations between the Merap and Tembau became peaceful. Later - probably between 1820-1830 - the Merap, and some of their allies, moved to and settled at Tukuk Apa' - a mountain in upper Kalun. Here Ncau Alang died and was succeeded by his son, Alang Ncau. This may have happened around 1830, or perhaps 1840, as Sellato (1995a) suggests.

\section{$1830-1850$}

Alang Ncau strengthened the relationship between the Merap and local Punan bands further. They moved from Tukuk Apa' to Long Pada in the upper Tubu, but probably for a few years only. Sellato suggests that some Merap may have stayed in the upper Tubu, eventually settling at Long Kendai, downstream from Long Pada (Sellato 1995a). It is also possible that there was an exchange of people between Merap and other Bahau groups living in Tubu at that time. In any case, Alang Ncau soon moved from Long Pada to the Arah River in the upper Malinau, where he established a village at the top of a mountain called Tukuk Nyurat. This village was built like a fort, with palisades. For defensive reasons, a large number of logs were tied at the slope on one side of the mountain. On all other sides of the mountain Punan stood guard. On one occasion a large group of Kayan arrived and started moving uphill. The Punan however, soon fiercely attacked them. Poisoned arrows were showered down upon them and they quickly retreated downhill, only to make a new try on the other side of the mountain. Here they did not encounter any Punan, and they could easily move quite far uphill, but they were finally stopped by large logs that were sent tumbling down upon them by the Merap. During their movement around the mountain, the Kayan had been followed by the Punan, who now attacked them from behind. On this occasion all the Kayan, except two headmen (Bit Dam and Pai Luhung), were killed, according to Merap (Langap) oral history.

From Tukuk Nyurat the Merap moved with chief Alang Ncau to the upper Kulih River (possibly upper Malinau?). They later moved downriver to Aking Dengon, a location just downstream from Liu Mahan. Alang Ncau is supposed to have married a Berusu' woman by the name 


\section{AN ETHNO-HISTORIC SKETCH}

of Lohoi Ibung. Merap oral tradition suggests that she was a sister of a Berusu' man named Kompoi Ibung, probably from the middle part of the Malinau River. Alang Ncau had several children, Lungu Alang, Arau Alang, Ura Alang, and Ibung Alang. Alang Ncau probably died at Aking Dengon/Liu Mahan.

It was probably during the time of Alang Ncau that the Merap began showing a growing interest in the bird nest caves in Seturan and Rian. This also led to conflicts with the Berusu'. It was also at this time that a small group of Kenyah Leppo Kuda arrived from the Lurah River, via the Aran River, to Malinau. ${ }^{16}$ Sellato (1995a) suggests that this happened around 1840.

\section{$1850-1900$}

Alang Ncau's sister's son, Alang Mpang, succeeded him. The group moved from Aking Dengon to Gunung Luhing, where Alang Mpang married his first cousin, Ura Alang, younger sister of Lungu' Alang. Due to internal conflicts, the group split at this time. ${ }^{17}$ Arau Alang, brother of Lungu' Alang, did not get along with Alang Mpang and therefore moved to the Lue' River (and later, via the upper Lue', into the Hong River area). The major group, headed by Alang Mpang, moved from Gunung Luhing to Gunung Bupah and then to Ngun Cibau - situated on a mountain somewhere on the east side of the Lue River.

When the Merap, with chief Alang Mpang, were living at Ngun Cibau, Lungu'Alang (son of the former chief, Alang Ncau), was probably old enough to become a leader, or perhaps a co-leader, with his cousin Alang Mpang. Lungu' Alang also married at Ngun Cibau and had several children: La'ing Lungu', Ncau Lungu', Ibung Lungu', and Lahai Lungu'.

From Ngun Cibau the group moved to the Gunung Hut River (just upstream of Pelancau), and a few years later to Long Pelancau. In order to get closer to the bird nest caves in Seturan, they soon moved farther downstream to Long Lemirang (just a short distance downstream from Pelancau), then Long Pasang (just upstream from Long Uli), and soon thereafter to Tabau Baung - a mountain not far from Kuala Kelawit. ${ }^{18}$ Alang Mpang died at Tabau Baung. 


\section{AN ETHNO-HISTORIC SKetch}

Lungu' Alang and his older cousin (father's sister's son), Alang Mpang, established rights to the bird nest caves in Seturan and Rian. The original owners of these caves were the Berusu', but they left the area under the pressure from the Merap. Later the Merap, and the Tidung, also dispossessed the Berusu' of the caves in Gong Solok. ${ }^{19}$ It was also Lungu' Alang who established relations with Panembahan Raja Tua probably around 1860. Panembahan Raja Tua was a Muslim Raja and the leader of a Malay petty kingdom, or kerajaan (B.I.), at Kuala Bengalun and, later, at Pulau Sapi. At this time Arau Alang - brother of Lungu' Alang — was settled along the upper Hong River.

When Lungu' Alang died, probably at Tabau Baung, he was succeeded by his younger brother, Ibung Alang ${ }^{20}$. He established peace with neighbouring groups, such as the Kayan Uma' Laran, and travels became safer and trade easier. Ibung Alang was succeeded by La'ing Lungu' (the son of Lungu' Alang), who strengthened the (trade) relations with Panembahan Raja Tua. In order to make their relations easier, he moved from Tabau Baung to Jaukuya, (perhaps also to Kuala Kelawit) and later to Langap, farther downstream. His younger brother, Ncau Lungu', split from the main group and established himself at Gunung Jaskau, Balah Uma' (Seturan River), where he guarded the Rattan Sega plantations.

\section{From I 900 onwards}

When Panembahan Raja Tua died, Panembahan Raja Pendeta succeeded him. It was also at this time that La'ing Lungu' died in Langap, probably at the turn of the century, i.e., around 1900. This was approximately a decade before the Dutch arrived. La'ing Lungu' was succeeded by his son, Alang La'ing, who was the Merap chief when the Dutch arrived around 1914. It was particularly during this time that trade in bird nests and NTFPs became increasingly important. Various traders began to visit the villages upstream.

His son, Mpang Alang, who was born in Long Kelawit and who later died in Langap, later succeeded Alang La'ing. The Dutch and the Sultan of Bulungan made him 'Kepala Besar Sungai Malinau/Tubu'. It 


\section{AN ETHNO-HISTORIC SKETCH}

was quite common in Kalimantan that the Malay sultanates and, later, the Dutch administration supported the position of certain prominent leaders and gave them official recognition as regional leaders (Sellato 1997). When Mpang Alang died, his son, Alang Mpang, who was born in Liu Tanam, succeeded him. He received the title 'Raja Besar Sungai Malinau'.${ }^{21}$ He had four children: ${ }^{22}$ Mpang Alang, Aran Alang, Nyihan Alang, and Lungu' Alang.

Ncau Alang succeeded Alang Mpang as headman in Langap in the 1950s. Later, in 1965, Alang Mpang's son, Mpang Alang, became headman in Langap (until 1990).

\subsection{OTHER GROUPS OF MERAP}

While some Merap stayed in the upper Malinau area, others moved to the Tubu River, or into the Hong River area and from there downriver (such as those in Laban Nyarit), or overland to the upper Ran River, and from there farther downstream (those in Long Adiu and Seturan). Many Merap, however, stayed in the Malinau River area and moved farther and farther down-river (such as those in Gong Solok and Langap). Others probably lived in Long Titi and Long Kapah on the Kalun River, before they settled in Long Kendai (Tubu). In the 1950s a part of this village moved to the Ran River and, finally, to Nanuk Tanah Kibang, where they mixed with the Punan from Sengayan. Those that remained in Long Kendai resettled to Respen Sembuak in the beginning of the 1970s.

Merap currently living in Sengayan Loreh moved from Tubu, perhaps from the Rat River, to the upper Sengayan River. Later they settled along the Ran River at Nkah Belaban, close to Kuala Ran. They probably moved back to the Sengayan River before the coming of the Dutch, around 1915-1920. 
An EthNO-HISTORIC SKETCH

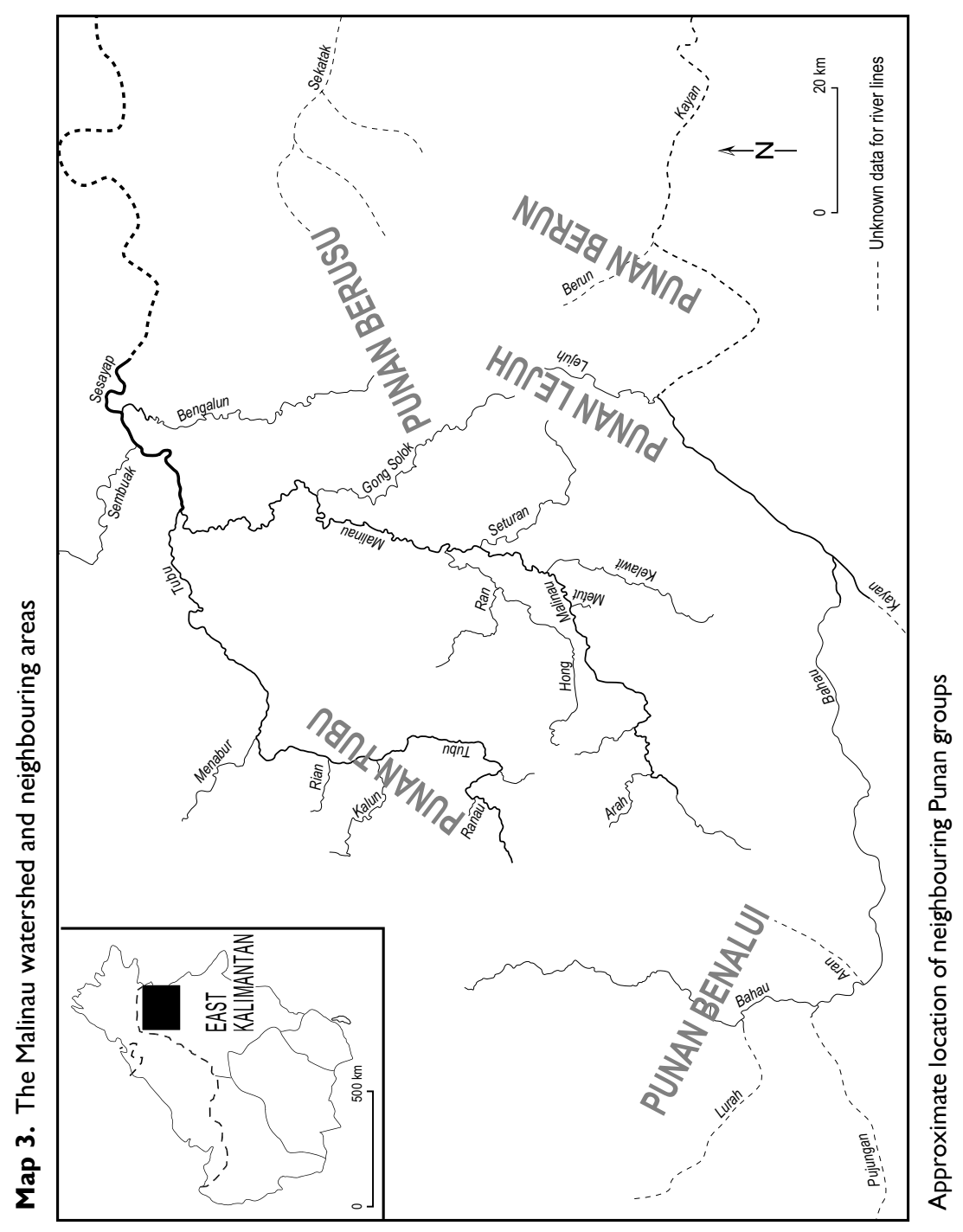




\section{AN ETHNO-HISTORIC SKETCH}

\subsection{THE PUNAN}

\subsubsection{Problems regarding historical reconstructions}

The distribution of ethnic groups and settlements within the Malinau district has changed considerably throughout history. Although the information we have had for the last 50 or 60 years is fairly accurate and detailed, the situation becomes increasingly blurred and fragmentary, especially from the 1920s. Although most Punan seldom remember the names of their great-grandparents, a few key informants have impressive genealogical knowledge, not only extending 5-7 generations back, but also including the genealogies of Punan living in different parts of the Malinau area, as well as the genealogies of farming groups' chiefs.

The problem when trying to reconstruct the history of nomadic groups like the Punan is that the fluidity at band level (migration and affiliation) can also be found at individual and nuclear family level. Each individual has a complex and distinctive genealogy, branching out far a field - and that especially applies to leaders. Nomadic groups generally got along all right with one another whenever they met and some degree of band exogamy induced inter-band and eventually some inter-ethnic mixing.

When ONE informant states that 'We, Punan Malinau, are of Punan Beketan origin', it just means the 'HE' personally has some — or maybe just one - Beketan ancestor, among others. His neighbour might have a completely different background. The problem is then, of course, to get the broader picture beyond individual variation. This is quite difficult because, not just the number of incoming migrants matter, but also their quality. One exceptional or prestigious apical ancestor would be better remembered in genealogies than many ordinary forefathers, and thus completely bias the appreciation we can have of historical interaction. This is certainly the case with the descendants of the few Beketan who arrived at the Malinau River and intermarried with local Punan from the Lake River and the Arah River areas.

In the following section I will, despite the difficulties mentioned above, try to present a sketch of the broader picture. 


\subsubsection{Are all Punan from the Tubu?}

As has already been stated, most groups of Punan along the Malinau River and its tributaries have their origin in the Tubu area. This applies not only to those groups who have moved to the Malinau watershed more recently, such as Punan Halanga (in the 1960s), Punan Long Rat (1970s), and Punan Bila' Bekayuk (1970s), but also (at least parts of) those Punan groups presently living in the upper Malinau. However, it also includes all, or a number of, the Punan Berusu', who are today living along the Gong Solok, Bengalun, and Sekatak rivers. The only exceptions would be those Punan Beketan who arrived in the upper Malinau at the end of the 19th century, as well as the Punan of the Lurah who accompanied the Merap to the Malinau area from the Lurah some 200 years ago. ${ }^{23}$

The picture is, however, not altogether clear. I have already mentioned the Punan Arah, who may have been living in the upper Malinau already two centuries ago, i.e., when the Merap arrived. They may have been early associates of the Berusu', or they may even have arrived in the upper Malinau from the Tubu area, but - and this would be the important point - they did not, in that case, arrive in the upper Malinau with the Merap, but prior to their arrival. It should also be noted that the tributary of the Malinau where they have been living, the Arah River, has its headwaters at the border of the upper Tubu area and are thus directly adjacent to the uppermost part of the Tubu area. The Arah River can be seen, if not as a part of or an extension of the Tubu area, then at least as the main route connecting the upper Malinau with the upper Tubu (and middle Bahau). ${ }^{24}$

According to Merap oral history, the Merap established relations with a number of Punan bands when they arrived in the Malinau/Tubu area. These bands were living in the Tubu, ${ }^{25}$ and these bands became the followers of the Merap, and they later joined the Merap moving to the Malinau watershed. ${ }^{26}$ From an old Merap document ${ }^{27}$ we know that one of these leaders, Irang Ipu' (Kalun), kept watch over Gunung Hingkah and the area between the Kelawit and Mekayan rivers. Others, like Uku Lepi (Menabur), kept watch over some of the caves of the Seturan/ 


\section{AN ETHNO-HISTORIC SKETCH}

Rian. Other groups occupied other areas bordering neighbouring watersheds, such as the Bahau or various sections of the Kayan River.

This information comes close to what Bare' Tangga' pointed out in an interview in 1991 (Nov. 25), when he said 'all Punan were probably living in Kalun, Rian Tubu, and Menabur in the past'. Even if this is the case, it doesn't mean that various Punan bands avoided the Malinau watershed and confined themselves to the Tubu area. The various routes connecting different watersheds were probably used as much in the past as they were used in the early 1990s. Just as there are routes connecting the upper Tubu with the Arah River and the upper Malinau, there are routes connecting the upper Tubu with the Ran and Hong rivers. Bare' Tangga's own genealogy contains information about a forefather, M'bui (see Appendix 6), who lived and probably died on the Seliban River, a tributary of the Hong River. His son, Ubang, married a woman from Hangrat in the upper Tubu, and therefore left the Hong (after the death of his father).

M'bui and Bare' Tangga' encompass seven generations. It seems likely that this M'bui was a grown man already when the Merap arrived in the Malinau/Tubu area around 1800. Bare' Tangga' visited the Seliban River in 1972, when he was doing a survey for a logging company. At that time it was still possible to find some traces left by M'bui and Ubang, e.g., fruit trees, some jar remains, and even the remains of the posts of a rice barn. This information is important; the question is how to interpret it. Does it mean that the Punan were growing rice at this time? Or are these the remains of another group, perhaps Berusu' - who did once live along the Hong River.

Ncau Usat — an old Punan Metut man presently living in Long Uli - mentioned that one of his early ancestors, Mpang Jalee, met the Merap, under chief Alang Ncau, when they first arrived in Kalun (i.e., around 1800-1820). Mpang Jalee, his younger brother To' Ilau, ${ }^{28}$ Lawing, Irang Bekiki, and Utan Pilak ${ }^{29}$ joined the Merap when they moved from Tubu to the Malinau area. Where in the Malinau area these Punan were living - i.e., the ancestors of the Punan Metut - Ncau Usat did not know, only that their descendants were living along the Kubaa River (situated just upstream from the Mekayan River) when the Dutch arrived 


\section{AN ETHNO-HISTORIC SKETCH}

and ordered them to settle in a 'proper' village at Long Metut (see also Appendix 5).

Unyat Iman - an old Punan Pelancau man presently living in Liu Mutai - also traces his origin to the Tubu area (see Appendix 4). His forefather, Uku Dangii, left the Tubu at the end of the 19th century. He did not, however, move to the Malinau area as a member of a whole band, neither was he moving on the initiative of the Merap, as Mpang Jalee did (see above). The reason for his move may have been marriage to a woman from the Malinau area. It is therefore important not to draw the conclusion that Uku Dangii is the forefather of all Punan Pelancau. Actually, Uku Dangii joined a group of Punan in the Malinau who, already at that time, had been living there for half a century or more. While some Punan Pelancau can trace their origins to the members of this earlier group, others can trace their origins to Uku Dangii, and still others to Punan Beketan.

\subsubsection{Punan Beketan}

The Punan Beketan have played a significant role among the Punan in the upper Malinau. Even though they were very few, their descendants have often been the leaders of different Punan groups. This is, to some degree, still the case.

So, when did the Punan Beketan arrive? How many were they? Where did they come from? Answering these questions is not altogether easy, as the information given by different informants is sometimes inconsistent. What we do know is that the Punan Beketan arrived in the Malinau area at the end of the 19th century, probably around 1880, in order to collect forest produce. It also seems clear that there was more than just one group of Punan Beketan that arrived. Aran Ipu' - a very old Punan Lake man from Long Kirau - mentioned two groups, the Beketan Puloh (who have descendants among the Punan Pelancau today) and the Beketan Kenawit (which included his own forefather, Maring), both of them arriving from Sarawak. Maring Ipu' — an old man from Long Jalan — only mentioned Beketan Punoh (which, according to him, 


\section{AN ETHNO-HISTORIC SKETCH}

included his own forefather, Maring). Another old man, La'ing Iman a Punan Pelancau from Long Metut — talked about one group of Punan Beketan that included a man called Maring. This group arrived from upstream. A second group of Punan Beketan arrived from downstream and included two men, known as Jenuko and Bage.

Irrespective of the number of Punan Beketan who arrived in the Malinau, only those few who married local Punan women — like Maring and Jenuko - remained in the area. Although most informants talk about small groups of Beketan, consisting of fewer than ten men, there are informants who mention higher figures. One of them is Bare' Tangga', who recalls a local narrative where it is stated that 27 Beketan arrived. The story goes like this:

A parang (machete) was stolen from a Merap graveyard. As the Merap didn't suspect the local Punan - who were afraid of burial grounds they met with the newly arrived Punan Beketan and asked them if they had stolen the parang. The 27 Beketan confessed that this was the case, as they didn't have any good parang and they badly needed one. As the Merap were eager to have the Beketan stay in the Malinau area they did not want to kill them. Instead they suggested that the Beketan should pay a fine: 'We ask for humans', the Merap said. The Beketan accepted this offer and went off and later came back with many human heads and many slaves, which were given to the three Merap chiefs in Malinau, Ran, and Hong. Having done that, most Beketan left the Malinau area, with the exception of two men who married local Punan women.

One of those who stayed was Maring, a heavily tattooed man who came from - according to different informants — the Mahakam or the Kenawit. ${ }^{30} \mathrm{He}$ came in the company of a few friends, some of whom also married local women, while others returned home. Among those who stayed, one, known as Sawing, married a Leppo' Ke from Long Lat, Bahau. Another man, Moceng, married a Payah woman from Seturan.

When Maring arrived in the Malinau area, he first came across the Punan Arah, who initially were afraid of him. His tattoos made a particularly big impression on the local Punan; it is still something often mentioned when people talk about Maring. He later visited the Hong 


\section{AN ETHNO-HISTORIC SKETCH}

River, where he met the Merap. A bond of fictive kinship was created between Maring and the Merap chief. This was called pecabila' (B.P., to establish brotherhood), ${ }^{31}$ a practice still common when a special bond is created between two unrelated persons from different ethnic groups. Maring and the Merap chief also made a blood pact, in which they drank each other's blood.

Maring married a local Punan Arah woman, with whom he had two sons, La'ing and Oyang. When his first wife died, he remarried and from this second marriage he had two more sons, Atung and Ipu' (see Appendix 7). It seems that Maring was living in an area that had its centre around Kuala Lake in the upper Malinau. This is also the reason why he seemed to have spent so much time on the upper Hong River. Both Maring and one of his sons, Atung, died and were buried in Lian Utun, upper Hong River.

When the Dutch arrived, the local Punan were ordered to make 'proper' villages, and it was at this time - probably in the 1920s — that Long Lake became a village. It was a rather large village and would be so until the Japanese occupation, when all Punan upstream left their villages to live in the forest. The sons of Maring did not get along too well, as they all aspired to become the leader and headman of Long Lake. This conflict or competition between brothers was the reason why Oyang Maring moved to Liu Mahan with a number of followers. ${ }^{32}$ La'ing and Atung remained in Long Lake, while the youngest brother, Ipu' Maring, went to the Arah River to look for followers among the Punan Arah. This happened in the mid-1940s, after the Japanese occupation and World War II.

Jenuko and Bage headed the second group of Punan Beketan that arrived in the Malinau area at the end of the 19th century. They arrived from downstream, according to La'ing Iman (from Long Metut), but they also seem to have come across and spent time with the Punan Arah, at the headwaters of the Malinau River. Jenuko married a Punan Arah woman, while Bage soon left the area. However, before Bage left, he wanted to kill Maring and strip his skin, as he was a slave. However, Jenuko did not agree. 


\section{AN ETHNO-HISTORIC SKETCH}

In any case, it appears that Jenuko, as well as his son, Kelaput, lived and died among the Punan Arah in the upper Malinau. At this time Maring and his sons were living in the Lake area. The son of Kelaput (Iman) married a woman (Iping) from Pelancau and moved to her group/ hamlet (see Appendix 4).

\subsubsection{Punan Arah}

As has been indicated before, the Punan Arah may have been early associates of the Berusu'. It seems likely that they had already been living in the upper Malinau, i.e., along the Arah River, before the arrival of the Merap. They may have migrated within an area that included the upper Tubu, as well as the Arah River, but all this remains unclear.

What we do know is that various other groups of Punan mixed with the Punan Arah during the 19th century and thereafter, such as 1) Punan from the Lurah who joined the Merap moving to the Malinau some 200 years ago, and, 2) the individual Punan Beketan who intermarried with the Punan Arah in the 1880s or 1890s (Maring, Jenuko), or who joined them in the late 1940s (Ipu' Maring).

If we look at the present situation, we notice that seven families (two houses) in Long Jalan can be classified as Punan Beketan, as they represent the descendants of Maring. On the other hand, there are currently 27 families who are more correctly classified as Punan Arah. Even though the Punan Arah constitute the overwhelming majority of the Punan Long Jalan, there has only been Punan Beketan headmen in Long Jalan for the last fifty years, i.e., since the arrival of Ipu' Maring. The last headmen of Punan Arah origin was Ula' Yuh and his son Lireh. From the late 1940s until today only the descendants of Punan Beketan have been headmen in Long Jalan. When Ipu' Maring died in the 1970s, he was succeeded by his son, Maring Ipu'. Ajang Maring was headman from 1991 to 1995; Ingan Ipu' was headman from 1995 until September 1999, when Iman Kre' was appointed village headman (kepala desa). It should also be mentioned that there have been relations between the Kenyah of the Bahau and the Punan of the uppermost Malinau. This has been the case between the Punan Long Jalan/Punan Arah and the Punan Lake since at least the 1940s. However, some of these relations may be 


\section{AN ETHNO-HISTORIC SKETCH}

much older than that. The Punan of the upper Malinau had probably been in some contact with the middle Bahau (Long Kemuat to Long Uli, mainly Leppo' Ma'ut) before the arrival of the Dutch. There were probably also relations between the Long Pujungan area (Uma' Alim) and the uppermost Malinau via the Aran River.

The Punan Long Jalan once had a village close to the mouth of the Arah River. However, since then they have lived at several locations along the Malinau River, such as at the mouth of the Jalan River (Long Jalan), at Mpoo, Lirung Kirip, or Nkah Bulu (the present location of the village). Today they have most of their rice fields and gardens close to the old village site of Mpoo, as the land above this site is fairly flat and therefore under cultivation as often as possible.

\subsubsection{Do all Punan have a common origin? A comment}

The Punan in the lower Kayan - with the exception of the Punan Lejuh - have their origins in the Bahau (e.g., Punan Berun, Punan Lasan, and Punan Benyaong) and they moved down the Kayan River to their present locations more than 150 years ago, accompanying the different Kayan groups. Another group of Punan from the Bahau joined the Merap from the Lurah moving to the Malinau some 200 years ago. This means that the Punan groups of the lower Kayan River are distantly related to the Punan of the Lurah who joined the Merap going to the Malinau, where they mixed with the Punan Arah. These Punan of the Lurah should not be mixed with the Punan who are living in the Lurah today, the Punan Benalui, who came to the Lurah area from Sarawak only 100 years ago.

In the lower Kayan there is also, besides these Punan groups from the Bahau, one group that is known as the Punan Lejuh. These Punan, who are living in Long Peso' district today, have their origins in the Malinau area and they belong to those groups of Punan who inhabited the Malinau prior to the arrival of the Merap. In that case, they are related to the Punan Berusu' (i.e., Punan Gong Solok, Punan Bengalun, Punan Sekatak), and probably also the Punan Malinau and Punan Tubu.

A possible hypothesis is that the Malinau and Tubu areas were once inhabited by local bands of Punan who were quite similar. In the mid-18th century, these local groups vacated the Malinau and split into 
two subgroups. Some of these local groups went to the east with the Berusu', while others remained in the Tubu. The question remains why the Malinau (at least the upper half of the river) was vacated during the last decades of the 18th century. The most probable explanation is the occurrence of Kayan raids from the Long Peso' area. ${ }^{33}$ Kayan raids were thus a common occurrence both before and after the arrival of the Merap in the upper Malinau (Sellato, pers. comm.).

\subsection{THE ARRIVAL OF THE KENYAH}

Various groups of Kenyah ${ }^{34}$ from the Bahau and Pujungan began moving into the middle part of the Malinau River in the 1960s and 1970s. Before each group started their migration, they first had to visit and make an agreement with the local leaders in the Malinau, especially Ncau Alang and Mpang Alang in Langap. At this time there was little competition for land, as population densities were low, and the villages were often far apart. When an agreement had been made, the various Kenyah groups started their move from their villages in the Bahau or Pujungan. Most of them did not move straight to their present location, but in stages, settling in for at least one year in one temporary village midway. In many cases, only a part of the village made the initial move, and additional families moved later, continuing thus for as long as a decade or more.

Among the first Kenyah to migrate to the Malinau were several groups of Kenyah from the Pujungan River. Probably the first were the Kenyah Uma' Lung, who began moving from Pujungan to Batu Kajang in 1962 (perhaps accompanied by some Kenyah Leppo' Ndang), and to Setulang in 1964-65. In 1964-65, the Kenyah Uma' Lasan also started their movement to Setarap, and the Pua' to Tanjung Nanga.

In the late 1960s the Kenyah Leppo' Ke began their movement from Pujungan and various villages on the Bahau to Long Loreh. This migration continued for more than a decade. The Kenyah Leppo' Ke and Nyibun in Gong Solok began moving from their villages on the Bahau between 1972-1975. 


\section{Ethnicity and Political Leadership}

\section{I. IDENTITY AND ETHNICITY}

In this report I talk about the various ethnic groups in the Malinau area as if they were separate and easily identified, bounded units, each one with a separate origin and a separate culture. The reality is, however, much more complex. Although I have no intention of going deeper into this issue in this report, there are a couple of interesting and important points I would like to make.

People in Central Borneo have, to a large extent, identified themselves with reference to localities, such as the river or side stream where they were, or had been, living. That local people identified and organized themselves in a different way than how they were perceived and labelled by the colonial, and later, national administrations, has been pointed out by several authors (e.g., Babcock 1974). Social scientists working in Borneo were for a very long time occupied with the question of ethnic classification. Much of this can be seen within the context of colonialism and of administering and creating order out of a very complex social reality. An interesting example sometimes mentioned in the literature is the creation of an ethnic group by the name of 'Kelabit'. Today there is such a group of people, who recognize themselves and who are recognized by others, as Kelabit, when actually this label was created by a 
misunderstanding. An administrative officer asked a local man what 'tribe' he belonged to. The man answered that he came from Pa Labid, which means the 'Labid River'. The officer understood this as 'Kelabit', and so began this particular ethnonym. Nonetheless, the people of Borneo may not have identified themselves as static, named ethnic entities, in the way they were perceived and labelled by early explorers and the colonial administration, but they have, of course, adapted themselves to and been influenced by this means of classifying and ordering people. They do use ethnic labels in various situations, but they do not necessarily think about themselves in this way in most situations in their everyday life (cf. Rousseau 1990: 11).

In reference to the Punan, we could ask ourselves in what way these various groups in the Malinau/Tubu area actually identified themselves one hundred or two hundred years ago. To what degree, and in what situations did they use terms like 'Punan' to identify themselves or others? To what degree was 'Punan' a label that was used to tag anyone who lived as a hunter-gatherer? Or to what degree was this perceived as something primordial? How permeable was the boundary between the Punan and others? It is rather significant that Punan, as well as other groups in Central Borneo, identify any people with a 'primitive' appearance - whether American Indians or Philippine Negritos — as 'Punan'. This identification is done by just looking at a picture. Physical appearance suffices to label anyone as "Punan". This is the case among the Sarawak Penan, as well as among the Punan Malinau/Tubu and probably any indigenous group in Central Borneo. The label 'Punan' says something about the 'occupation' (hunter-gatherer) of the beholder, and perhaps also something about his (subordinate) position in a wider social context. The term 'Punan' thus has an economic, as well as political, dimension.

The colonial and, later, national administration has probably had great influence in the way this term has been used during the last century. What has happened during the last 10-15 years, particularly in Sarawak, will probably have a profound impact on the way in which this ethnic label will be used during the years to come (see also Chapter 6). 


\section{EthNicity AND Political LeAdership}

\subsection{SETTLEMENT PATTERNS}

The Punan have a number of words to describe various forms of dwellings and hamlets. The most temporary kind of shelter, often used for a single night, is called a tulung, a lean-to. An ordinary kind of hut, usually inhabited by a single family, is called a lepow, while a larger hut, or house, is called a lefu'. When a small number of families, usually what can be described as a band, reside in a particular place, they do not describe this place as a village, but simply use the word lun, which means 'place'. A small, more or less temporary hamlet, consisting of 2-4 huts, lepow, is therefore referred to as ji lun (lit. one place). A larger and more permanent concentration of huts is called a tukung, or village/hamlet.

Before the arrival of the Dutch in the 1920s, the Punan Malinau did not reside in villages, i.e., what they themselves refer to as tukung. It was probably during the 1920 s that the local Punan upstream on the Malinau River were induced to build larger settlements at Long Lake, Pelancau, and Long Metut.

Although the Punan of the Malinau/Tubu area were more numerous than the Merap or the Abai, local groups of Punan were not organized into higher level units; instead, they interacted with neighbouring groups as local groups/bands. These groups were affiliated to particular Merap or Abai groups or villages. Some of the differences that can be observed between different groups of Punan within the Malinau/Tubu area today are partly a result of such alliances - a theme I will return to below.

\subsection{The family and the band - nomadism and village life}

Mufut, or deh mufut, is a word/expression in the Punan language that means 'to move from place to place'. ${ }^{35}$ Even though there are no truly nomadic Punan in the Malinau/Tubu area today, individual households may spend shorter or longer periods in the forest, doing something they themselves characterize as mufut. When groups of men spend several weeks in the forest looking for eaglewood they do not mufut. The collection of NTFPs for trade is classified by Punan as nguca', a word 
related to the term ngusa' in the local Malay vernacular, which corresponds to the Indonesian word usaha (effort, exertion, labour, work, trade) and its associated verb forms, such as berusaha (endeavour, run a business), or mengusahakan (organize, manage, make an effort). In comparison, to go mufut always involves whole families, including men, women, and children. The fruit season is the most typical occasion when whole families leave their permanent settlements in order to spend a few weeks in the forest. During such occasions there are, in every village, a number of empty and seemingly abandoned huts/houses. When people are asked why certain houses are empty, they may answer that those families have gone mufut, or that 'they have gone to eat fruit and pig'.

It is interesting to note that the Punan word bufut - a word closely related to the word mufut - may be translated as 'family'. ${ }^{36}$ The Punan themselves translate bufut as 'satu KK', referring to 'satu kepala keluarga' (B.I., one family head), i.e., the modern residential unit, the modern version of the traditional nuclear family. The only word, besides bufut, that has a meaning that (in certain contexts) comes close to "family" is pipah, meaning 'to be siblings/relatives'. Pipah is comprised of a verbal prefix, $p i-$, and a root, ipah, meaning 'relative', as in ipah la'ung, real (blood-) relative. It's interesting that the Indonesian word keluarga (family) is translated by the Punan as either bufut, 'one family head', or as pipah, 'to become relatives'. This could refer to the kinship composition of migrating bands in the past, that is, a set of siblings and cousins (plus spouses) descending from one apical forefather, the original family head of the band. The original meaning of bufut would be that of a 'group of migration', i.e., a 'band', whether the group is 'staying together' or 'moving together'. It may refer to both the residence unit (group of people staying together in a hut) and the migration unit (group of people migrating together), irrespective of the fact that the former is a nuclear family and the latter a band. The reference to the one or the other would then be context dependent. ${ }^{37}$

Although most Punan are, more or less, sedentary today, to go mufut may still, at the turn of the century, be rather common among most groups of Punan during the fruit season. However, the number of households that enter the forest more regularly and at any time of the 


\section{EthNicity AND Political LeAdership}

year has decreased considerably during the last 10 years. It is only among the Punan Halanga, Punan Mirau, and Punan Lake that a number of families still spend considerable time in the forest, i.e., mufut.

I suspect that the meaning of the word mufut has changed to some degree as the Punan have become increasingly sedentary. In precolonial days, when the Punan Malinau had no villages and lived a nomadic life, the word mufut was probably not used, as it is today, to indicate a contrast to village life. To go mufut is seen as a break from the daily routine of village life. Also in the past, mufut was probably seen as a way to break up a routine and to introduce some variety. ${ }^{38}$ To go mufut entailed, in the past as well as today, the excitement of hunting as well as the joyful consumption of wild boar and fruit. To go mufut has also been seen as a way to escape diseases. Two men from Long Jalan, both of them 30-35 years old, explained that their respective fathers never allowed them to attend school downriver when they were young. 'My father told me', one of them said, 'that it's dangerous. You catch the measles. Better to go mufut and build up your strength and resistance by eating a lot of wild boar'.

Today, to go mufut, can be a way to escape diseases by looking for 'a cool place' and to gain strength/health. However, it also means the possibility to escape the constraints of village life and to be free from having to live up to the expectations and norms set by others, free to engage in pursuits that give great enjoyment. As long as a Punan household lives in a riverside village, its members are to some degree constrained by the expectations of any outsider or potential visitor, not least representatives of the modern nation state. To go mufut is thus a word that has very positive connotations for the Punan themselves, at least among those who are still living upstream; at the same time, mufut is also the practice that is the most despised by the state representatives and something that most non-Punan regard as the most conspicuous sign of primitivism and backwardness. The practice engaged in when they go mufut clearly does not correspond to Indonesian state norms or its standards of modernity and normality. 


\subsection{2. 'Isolated peoples' and resettlement}

Not only the Indonesian government, but also the Dutch colonial administration, as well as the Christian missionaries, have invested much energy and effort to settle nomadic groups in permanent and 'proper' villages and to resettle 'isolated' people from remote areas to more accessible locations 'where they can be offered cultural, political, economic, and religious guidance' (Lowenhaupt-Tsing 1993: 28). This has obviously not only been a question of making it possible to provide health care and education to everybody, but to be able to civilize, control, and administer a population that is 'not yet ordered' (ibid.).

In Indonesia, more or less 1.5 million people are officially defined as masyarakat terasing (B.I., isolated societies). Approximately onequarter of these, or 400,000, live in East Kalimantan (Lowenhaupt-Tsing 1993: 92). For more than two decades, the official Indonesian concept for indigenous peoples has been masyarakat terasing, suku-suku terasing (isolated tribes), or desa tertinggal (left behind villages).

In the early 1970s the indigenous peoples of the Malinau area, who were living far upriver, became the focus of a civilizing project, the

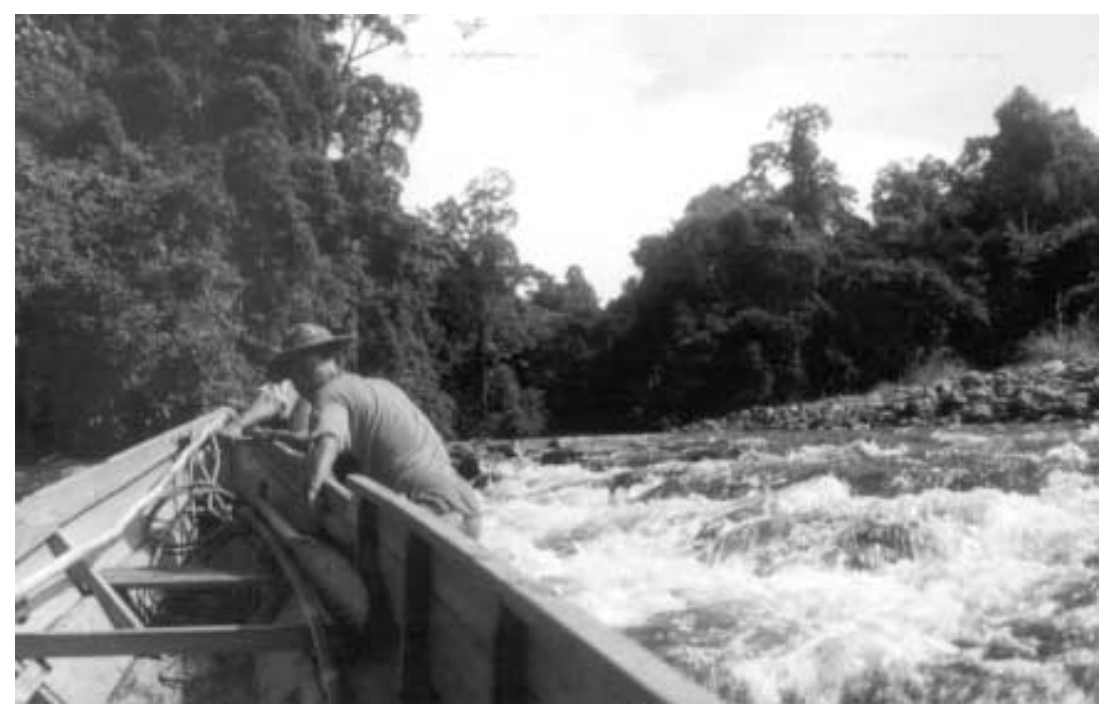

Resettlement has long been the favored policy to combat the isolation of communities that comes from poor accessibility 
Proyek Civilisasi Suku-suku Terasing. It was at this time that large numbers of people resettled downriver. The great majority moved in 1971, with the assistance of the Ministry of Social Affairs (DEPSOS), from their villages along the Tubu River to Respen Sembuak, a large resettlement village close to the district capital, Kota Malinau. This relocation of people from the Tubu included not only Punan, but also Abai, Merap, and other groups (Milau, Tembau). A few settlements also moved from Tubu across the mountains to the Ran River. These settlements later settled at Kuala Ran and Long Loreh.

In the Malinau, all upriver villages have officially resettled downriver. From 1972-75 the Punan Liu Mahan joined the Leppo Ke' and settled with them in Long Loreh. Later, in 1982, the Punan Pelancau split in two groups and one of them moved, with the official headman, to the resettlement village of Long Loreh. A few years later, in 1985, the Punan Metut split in two, and the headman moved with one of these groups to the resettlement village of Seturan. Shortly thereafter the headman of Long Lake moved downriver with a part of the village and settled in Seturan.

From the early 1970s until the mid-1980s approximately 1500 Punan resettled from upriver locations to resettlement villages in Respen Sembuak, Lubuk Manis, Long Loreh, Seturan, and Kuala Ran. Most of these Punan (ca 1000) resettled as whole villages from the middle and lower Tubu downriver, while the remainder are composed of Punan Malinau who moved as sections of split villages.

From the mid-1980s until 1999 there was officially only one Punan village, or desa, living upstream, namely Long Jalan. This village remained intact until 1999, when a few families took up residence in the newly built resettlement village situated next to Tanjung Nanga. All other desa were officially resettled downriver, although at least 50 percent of the population of these villages were still living upstream. This also means that, during the 1990 s and a part of the 1980 s, the only upstream settlement to receive village aid (BanDes), was Long Jalan, the only village with a government appointed headman. 


\subsection{LOCAL VARIATION}

Bare' Tangga' characterized the Punan in the upper Malinau as those still 'holding the tail', i.e., they are not free, but still the followers of the Merap, or the Kenyah. The Punan Tubu in Respen Sembuak, on the other hand, are qualified as 'free and educated', according to Bare' Tangga'. It's a big difference between these Punan, he explained, and he continued by saying that:

'The Punan in upper Malinau are afraid. The Punan in Respen Sembuak are not. The Punan Malinau are afraid of other people, they always have been. The Punan Malinau do not resist or oppose things that affect them negatively. They do not know, do not understand, how to act like free people, who have rights to their land'.

That there are important differences between various groups of Punan was obvious also to an early visitor, like Tom Harrisson, who travelled through the Tubu area in the 1940s. He says that this river was 'mainly controlled by settled Punans, some of them very sophisticated'; these Punan were 'rich and business-like' (1975: 3). In this case he refers to the Punan of the lower Tubu, some of whom were living a life that probably was inseparable from that of the Abai. Some villages in the lower Tubu were also ethnically mixed villages. However, in his book World Within, Harrisson also paints another picture, saying that 'in the Toeboe [Tubu] and related rivers, there were numbers of nomadic people, Punans ... [who] roam in small bands over great distances, without cultivating anything; living off wild vegetables and game' (1986[1959]: 265-6). This difference, between the 'rich and business-like' Punan Tubu and other groups of Punan (including certain groups in the Tubu, as well as many of those in the Malinau River area), continues today. One reason behind the variation that Harrisson observed more than 50 years ago is to be found in the relationships between local Punan groups and their closest agricultural neighbours and allies.

Generally speaking, Borneo nomads often have intermarried and become assimilated into non-stratified groups of rice farmers, whereas they have not done so with strictly stratified groups, such as the Kayan or Kenyah. Lack of stratification makes assimilation easier (Sellato 1994: 


\section{EthNicity AND Political LeAdership}

183-4, 212; Rousseau 1990: 245). Several Punan groups in the Tubu area were affiliated to less stratified groups, such as the Abai, Saben, Merau, and $\operatorname{Ngurik}^{39}$ (as well as with Merap of mixed or 'lower' status), groups which are characterized by a more 'open' social organization. The boundaries between these groups were permeable, and intermarriages between Punan and members of these agricultural groups were not uncommon. Superficially the Abai can be said to be stratified, in much the same way as the Merap. They recognize various social strata and they regularly refer to their leaders as 'raja'. However, in practice the Abai system was rather different from that characterizing the Merap. Intermarriage between the Abai and other groups, such as Punan or Milau, was frequent. Various groups often lived together in the same settlements on the Tubu. A village like Long Nit (presently situated in Respen Sembuak) was actually composed of several ethnic groups that intermarried, i.e. Abai, Milau, and Punan. There were, of course, also Punan groups living farther inland, usually along smaller tributary streams, and these Punan traded with the leaders of the Abai and Merap villages; in this regard the relationship resembled that between the Punan and Merap in the Malinau, but the boundary between these groups was less marked along the Tubu. This is probably one important reason why the Punan Tubu have been involved in rice agriculture longer than other groups and why they have been more 'rich and businesslike' and more like their agriculturalist neighbours. This applies especially to those living along the lower half of the Tubu River and those have resettled to Lubuk Manis and to Respen Sembuak.

The Punan Malinau, on the other hand, were affiliated to the Merap, a more clearly stratified group, with whom they have very infrequently intermarried. The Merap were eager to have many groups of Punan living within their area, not only to have exclusive rights to the NTFPs collected by these Punan, but also - in former times - to have an 'army' that could defend the borders of their territory against enemies living on neighbouring watersheds. Most of these groups of Punan either followed the Merap or were asked by the Merap to move to and settle within the boundaries of the Merap area. Merap aristocrats organized the trade in NTFPs. Compared to the permeable boundary between the 


\section{Ethnicity and Political Leadership}

Punan Tubu and the Abai, the boundary between the Punan Malinau and the Merap was sharp and did not lead to intermarriages or co-residence.

As compared to the Punan of the lower Tubu, the Punan Malinau remained nomadic for a longer time and 'up to a short time ago, practiced no agriculture' (Sellato 1994: 177), at least no rice agriculture. The cultivation of cassava was adopted by the Punan Malinau much earlier, however, at least before the arrival of the Dutch. Although a few Punan Tubu individuals demonstrate extensive genealogical memories, the Punan Malinau can rarely recount more than a few generations. Prominent leaders, especially those of Punan Beketan origin, can present genealogies that indicate their relationship to an important forefather, but these genealogies are nonetheless shallow and narrow. Despite the differences sketched above, there is no clear and absolute boundary between these two Punan subgroups; they have been characterized instead by permeability, and there has been a great deal of movement of people between the different groups, especially through intermarriages.

The differences between various Punan that can be observed today include those described by Bare' Tangga' above. While the Punan Tubu are generally much more outspoken and today increasingly involved in a political struggle for attention and space, the Punan Malinau are more subservient towards agricultural groups, such as the Merap, and various external agents. The changes induced by the Dutch (for example, the abolition of slavery) and by the Indonesian government (administration without regard for local customs and local agreements), as well as the fact that all villages now have their own locally elected, but governmentappointed, chief, have more and more undermined the power and influence of the Merap chiefs. However, those Punan headmen who openly oppose the authority of the Merap are often of Punan Tubu origin. They make their own claims today and reinterpret history to their own political advantage.

Although younger men from the upper Malinau are impressed by the outspokenness of many Punan Tubu, many Punan Malinau elders do not understand the actions or the motives of the downriver Punan. They openly dissociate themselves from the agenda of the new NGO, Yayasan Adat Punan, and instead take sides with their former patrons, 


\section{EthNicity AND Political LeAdership}

the Merap. One old man in the upper Malinau explained his opinion by saying that: 'When the white and the black of an eye can be separated, only then can we (Punan) from upper Malinau separate from the Merap. We don't understand what the people (Punan) from Respen are doing'.

\subsection{LEADERSHIP}

Although the Punan Tubu/Malinau could be described as basically egalitarian, I am not at all satisfied with this simple characterization. The picture is instead quite complex and ambiguous. All the various Punan groups have had their own local leaders, often an older and experienced man who acted as the leader of a small local group, perhaps just an extended family. But there have also been more prominent leaders, called 'big men' (B.P., lei ayo'), 'brave men' (B.P., lei tebah), 'village chiefs' (B.P., lakin tukung), 'kings' (B.I., raja) or 'aristocrats' (B.P., lakin paren). Punan also claim to be stratified, in the same fashion as their agricultural neighbours. However, leadership is first of all a question of experience, knowledge, personal power, and oratory skill.

Even women could become leaders, or raja, among the Punan Tubu. One women mentioned is Ayom from the Bila' River, who had a 'mouth just as smart as that of men'. Cases of polygyny among Punan (Malinau/Tubu) have also been common among prominent leaders in the past, and are still encountered.

Generally, the Punan have very shallow genealogies and most of them are not particularly concerned about remembering the names of ancestors, or the history of their local group or that of their neighbours. Among local leaders, however, genealogical data has been considered very important. Extensive knowledge about history, genealogies, and oral tradition was characteristic of prominent Punan leaders, as were oratory skill, language skills, good humour, experience of other peoples and places, bravery, confidence, and generosity. Today, too, when older, knowledgeable men come together to talk about the old days or contemporary issues, it is often obvious to their audience who is the most knowledgeable among them. This is sometimes commented upon afterwards, in private. 


\section{Ethnicity and Political Leadership}

Obviously, genealogical data has been and continues to be of political significance to the individual leaders themselves. Today, this kind of historical and genealogical knowledge has also become politically significant in order to claim land rights and to legitimise these claims (see also Chapter 6). Previously, genealogical and historical data was important also in creating and maintaining relations to other groups of Punan, from other areas. Knowledgeable leaders were a kind of middlemen and brokers between local groups, just as they have acted as middlemen in relation to various outsiders, including the colonial and national governments. These roles as middlemen and brokers have now become, if not more important, then at least important in a new way. Today, however, many of the most talented local representatives are less knowledgeable about local history and they have not really spent much time in the forest; they are educated Punan who have lived most of their lives in cities or in large multiethnic villages, like Respen. This new category of educated representatives and leaders has now, however, become necessary.

Mostly Punan from the Tubu River inhabit the large resettlement villages near Kota Malinau (Respen Sembuak, Lubuk Manis), and there is evidence of a growing political awareness, which has been particularly visible among these Punan. Traditional leaders who still live upstream are often very gifted orators and advocates for their local groups. Although these men are highly respected and described as great men (B.P., $a$, ayo) by people upstream, downstream among Punan Tubu who have resettled to Respen Sembuak, these leaders have very limited influence. As a rule, these traditional leaders do not have much formal education and they are considered to be less 'developed', less 'modern'. A new type of leader, who has both education and much experience with outsiders, is emerging among Punan living downstream. 


\section{Recent Trends and Perspectives}

M any of the changes and developments that have taken place in the past few years in the Malinau area have had a number of negative consequences, but they have also brought many new opportunities. Chances for employment have increased to some degree, although much less than expected when considering the number of new companies that have entered the area. Proximity to timber camps has also given some households an opportunity to sell various products, such as fruit, fish, meat, or handicrafts. This has been the case for the Punan in Long Metut, Liu Mutai, and Long Uli, who have sold various products to workers at the timber camps in Kelawit and (for as long as it was in operation) Long Uli.

The arrival of a growing number of companies — timber, mining and plantation companies - has contributed to increased competition for land, but it has also created new opportunities. The activities of these companies are not necessarily perceived by local people as a threat to their livelihood: by claiming compensation for land that will be exploited, or for farmland that has been damaged, the encroachment of new companies is also perceived as a potential new source of income. I will return to this issue below.

In spite of such new possibilities to earn cash, the collection and sale of eaglewood has been unchallenged as the most important source 


\section{Recent Trends and Perspectives}

of cash throughout the 1990s. As stated earlier in this report, the price of eaglewood has increased dramatically since 1989. Developments, such as new roads and a dramatic increase in the number of long-tail engines, have had a series of consequences. Formerly, differential access to information about markets and prices made it easier for traders and other middlemen to exploit the Punan who lived far upriver. This situation changed in the beginning of the 1990s. The increase in the number of long-tail engines in all settlements gave local people better opportunities to sell their products downriver, bypassing various trader/middlemen. This development has not continued, however. The construction of roads has reduced the importance of the river as a means of communication as far upriver as Langap and Seturan. Farther upstream, where the rivers are still the main means of transportation of goods, the number of longboats and long-tail engines among local people has also decreased. The reason is not a growing importance of other means of transportation, as it is farther downstream, but the fact that people increasingly make other priorities. It is true that long-tail engines have become more expensive, especially after the monetary crisis started at the end of $1997,{ }^{40}$ but many households upriver have nonetheless been able to invest substantial amounts of money - 5-10 million rupiah or more - in building new houses. Building houses, instead of buying a means of transportation, seems to have increased the dependence of the upriver Punan on traders. The system of credit is, therefore, still very common and most upriver Punan have few possibilities to sell their eaglewood to other traders and thereby bypassing the trader to whom they are in debt.

\section{I. HEALTH}

Punan, especially those living upstream, are clearly disadvantaged when it comes to health care. During my visit to the upper Malinau in February 2000, a number of Punan, mostly children, died because of dysentery. Worst hit at that time was the village of Long Kirau, far upstream. In 1990-92 the health situation among the Punan was even more troublesome, 
especially among children, and something that people constantly complained about. The most common ailments were fever, anaemia, respiratory diseases (bronchitis, pneumonia, pulmonary tuberculosis), diarrhoea, stomach disorders, and various kinds of injuries. Punan men and women - often complained about dizziness and breathlessness. Most women suffered from anaemia, as the food consumed is poor in iron. Enlargement of the spleen was common among all Punan - a condition related to malaria. Chronic bronchitis was common, at least periodically, among most, if not all, men. An important reason may be the fact that all men are more or less heavy tobacco smokers. Quite common, among men as well as women, were complaints related to the upper part of the stomach (often classified as sakit maag). The main reason may have been gastritis. Among children intestinal worms were extremely common, especially in remote, upriver settlements. This can be compared to the situation in Sarawak, where infectious diseases abound, even though childhood immunization and malaria control programs have been implemented there with some success (Aspinall 1990: 71).
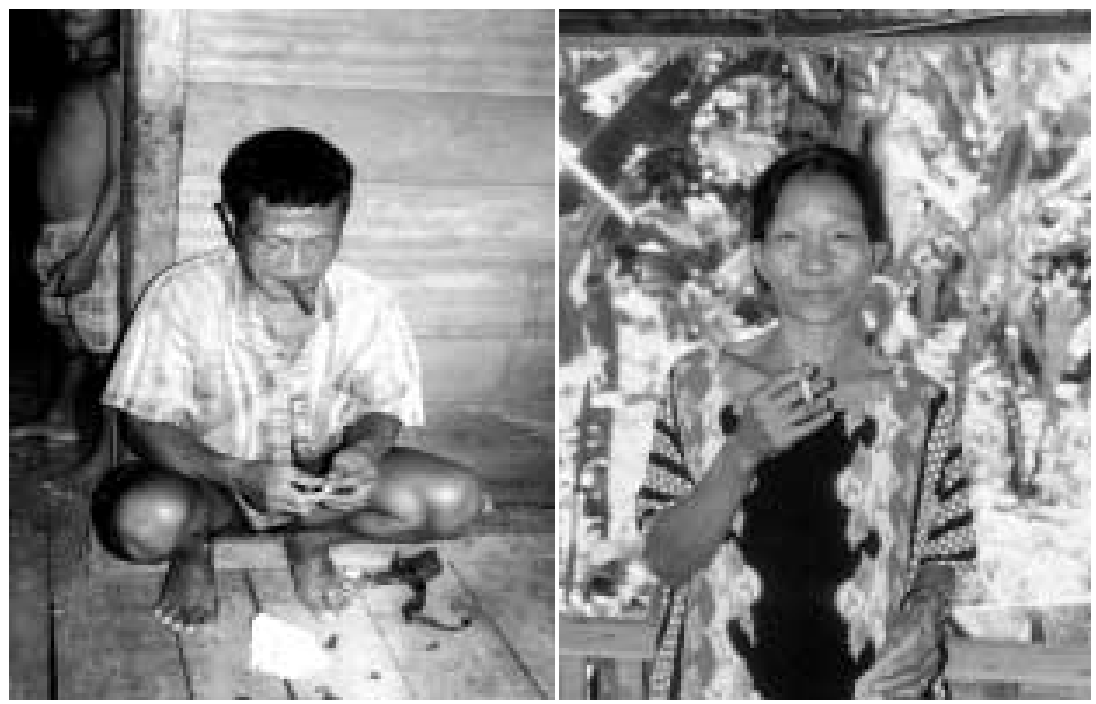

Men and women alike are heavy smokers 


\section{Recent Trends and Perspectives}

The data I collected in 1992 in a few small settlements upriver (Rian Tubu, Nkah Limpak, and Long Uli) indicates that more than 40 percent of all children died at an early age. Of 155 children born of parents living in these villages in 1992, at least 65 of them died before reaching the age of 5 years (i.e., 419/1000), and an additional 6-7 died before the age of 20 . The additional data I collected, rather sporadically, from other Punan settlements upriver, revealed a child mortality rate that was somewhere between 35 and 55 percent. Recent research among Punan Tubu indicates that the situation has not improved; while some upriver settlements have a mortality rate as low as 17-23 percent, in other settlements this figure rises to 46 percent and even 71 percent (Levang 2002). Miscarriages were, in 1990-92, fairly common, although I did not collect any data on this issue. I also lack data for the number of women who die in childbirth, but it was not uncommon and it was a risk that people were very well aware of and talked about.

These exceptionally high figures are based upon information from approximately 5 percent of all Punan households in the Malinau area. This high rate of child mortality could be incorrect for the whole population, but it is still an indication of a very serious health situation among children (cf. Knapen 1998). Among neighbouring groups of Punan living in Bengalun and Gong Solok, the situation may have been even worse. The reasons why these 65 young children mentioned above, and others, died were - according to the information given by their parents - fever, malaria, diarrhoea (with or without blood, vomiting, and fever), 'sakit kuning' (perhaps. hepatitis), measles, tetanus, or — very common because of spirits.

Malaria could probably be regarded as endemic in the Malinau area and a major reason why so many children die at an early age. Even in cases when malaria is not the main cause of death, it may still be an important indirect cause. Those children who survive to the age of 5 or 6 years achieve a certain degree of immunity, which probably is the reason why attacks of malaria can be rather mild among teenagers and adults. This achievement of immunity, or at least some degree of immunity, may also apply to other diseases, such as various forms of infections. The 
price for achieving this immunity is, however, very high, as it means that many children have to die.

Ten years ago most informants, especially old people, often pointed out that the health of the Punan had been much better in the past. Formerly malaria, which is now endemic, was an uncommon disease among nomadic Punan (cf. Knapen 1998). An old Punan Malinau man, perhaps 60-65 years old, commented that:

Now there are doctors and many kinds of medicines, but we are sicker than ever before. In the past we always drank water directly from the river without getting sick. Now we're sick even if we boil our water.

The Punan Malinau often compare their situation with that of the indigenous population of neighbouring Sarawak, East Malaysia. In Sarawak there are immunization programs for all children and good health care for everyone; there are even flying doctors for distant Penan settlements.

\subsection{PROGRESS AND CULTURAL AUTONOMY}

The Punan aspire to progress materially - the improvement of economic and social conditions, health facilities, roads, communication, and schools concern them vitally. This kind of 'modernization' is not seen as a threat to their own cultural autonomy or traditional lifestyle, but it is something that they all desire. What is considered to be a threat is any kind of 'development' that keeps them at 'the bottom' by discriminating against them, or that expropriates and exploits their land and resources without regard for their rights and welfare. According to Sahlins, "people are not usually resisting the technologies and 'conveniences' of modernization... Rather, what they are after is (...) their own cultural space in the global scheme of things" (1999: 410).

Especially among the Punan Tubu, education is considered extremely important in order to enhance the possibilities of not only the younger generation, but of the whole community. Education is seen as a 


\section{Recent Trends and Perspectives}

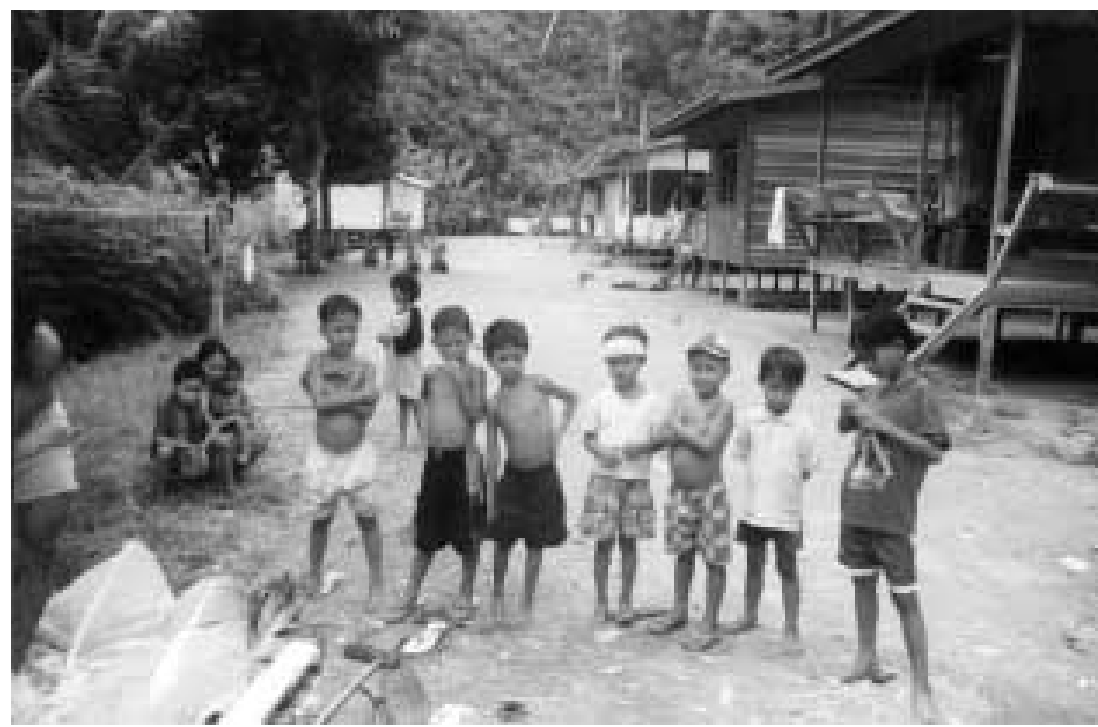

Nowadays, Punan hunter gatherers settle down in permanent villages

prerequisite to economic and political success, to their being able to assert themselves in relation to other local groups or to various external agents. Being able to read and write is important both to retrieve information from various written sources, and to be able to confront powerful others with tools that are respected and that can make a difference. Education is also important for those who aspire to enter the labour market, perhaps to become civil servants or teachers, or who wish to establish their own business enterprises, such as shops. Education is seen as an important key to the future. Living far upstream, Punan do not have access to schools.

Individual Punan Tubu often point out, proudly, that they have several close relatives who have a higher education, some of them are even doktorandus. ${ }^{41}$ Although most Punan admire those who are educated and smart, the Punan from the middle and lower Tubu especially value these traits and abilities. The present kepala adat of the PanPunan NGO, Yayasan Adat Punan (YAP), Lawing Tangga, is one of these educated Punan Tubu, who today is an important local leader and a source of much inspiration to the Punan. The Punan admire 'brave' men: men who are not afraid of, or intimidated by, any outsider; men who can communicate with anyone in order to advance their own interests 


\section{Recent Trends and Perspectives}

and those of their local groups: men who inspire courage in others. Today, this admiration extends to those Punan who are educated and conversant in the language of the administration, companies and NGO representatives. Lawing Tangga is especially the object of such admiration today; he is a very important representative of the identity and self-image of local Punan:

'The Punan, anxious to meet the farmers on an equal footing, want a leader of whom they can be proud. The prestige of the leader reflects upon the group' (Sellato 1994: 152).

It may even be the case that:

'.. the prestige of a leader known for his wisdom may attract individuals or families from other bands to join his own' (ibid.).

Several Punan have, in various ways, said that the Merap may have some bright people, who also are eloquent speakers, but if anyone of them had a conversation with Lawing Tangga, 'they would soon turn out to be real losers' (B.I., pasti mereka kalah).

\subsection{LAND RIGHTS AND TERRITORIALITY}

Ten years ago, in 1990, questions of land rights were not a hot issue along the Malinau. People never, or seldom, talked about such issues, with the exception of the discontent expressed by the Punan living in multi-ethnic resettlement villages, such as Long Loreh. In such areas, with a higher population density and increased competition for the best land, the Punan perceived themselves to be truly disadvantaged. However, aside from complaining about the situation among themselves, not much was done (or considered possible to do) about it.

Farther upstream, all land was considered more or less free among the various groups of Punan. Any group or individual, from downstream or upstream, could move around and extract resources, more or less, freely. The extraction of certain resources - such as sago - did of course require the prior consent of the owner, but that was usually no problem. Until recently there has been very little competition from outsiders 


\section{Recent Trends and Perspectives}

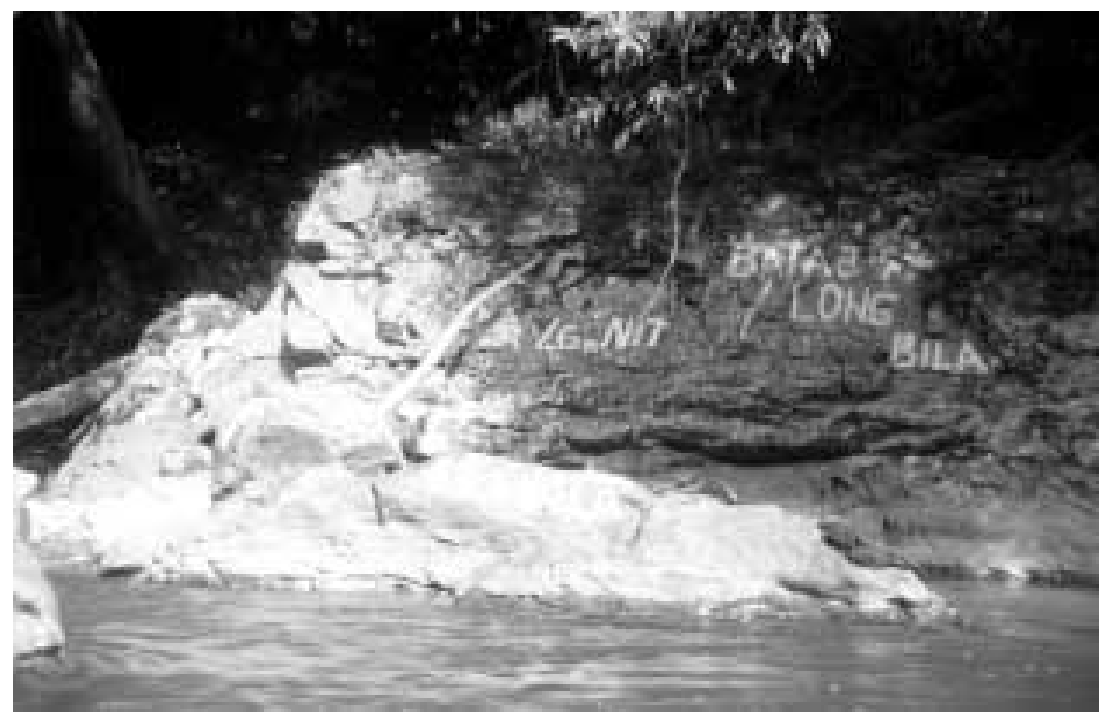

Recently, village boundaries have become a hotly contested issue even in the remotest areas (middle Tubu)

and very little reason for the Punan to defend the territories. Living in small bands, scattered over a vast area, the appearance of other small groups has not been much of a threat - at least not in reference to natural resources. There were plenty of such resources for all.

Since the early 1990s eaglewood has, however, attracted large numbers of collectors to the forests far upstream. Many of them have been collectors from downriver, such as Putuk, hired by traders from Kota Malinau. Already in 1991, large parties of collectors, sometimes consisting of 30-50 men, regularly went past local Punan hamlets far upriver. Some of them were on their way to the Bahau, or Tubu, others planned to stay in the upper reaches of the major tributaries of the Malinau River, such as the Hong River, the Kelawit River, the Metut River, the Mekayan River or the Menureh River. The local Punan at this time early 1990s - were rather worried about the large number of outsiders coming into their territories. However, few of them seemed to perceive this as an economic threat. They were rather concerned for their own safety. They simply didn't trust these strangers. May be some of them were 'bad people', maybe even head hunters (B.P., ngayow). Women and children in small upriver settlements often expressed their worries. 


\section{Recent Trends and Perspectives}

Sometimes they returned to the settlement in a great hurry, talking about ngayow. The reason was that they had noticed the smell of kretek cigarettes, which indicated to them the presence of strangers. There were also, especially in 1991, numerous stories circulating in the Malinau and Tubu about nightly visitors who threw stones at Punan huts far upriver. These visitors were most often described as invisible and ghostlike, although they sometimes left footprints in the mud or communicated with each other by means of nearly inaudible whistles. In cases where such visitors had been visible, they were usually dressed in much the same way as any collector of eaglewood, i.e., in baseball cap and T-shirt. The descriptions of these nightly visitors mixed, in various ways, three different kinds of frightening characters: evil-minded spirits, head hunters, and eaglewood collecting strangers.

Occasionally, individual Punan expressed worries over the depletion of eaglewood, but they never described the eaglewood collectors from downriver as intruders on their territories. They may have been described in another way if they had been looking for eaglewood right in the vicinity of a particular hamlet, but this was never the case. Most collectors were just passing by on their way to the headwaters of a particular, sometimes nearby, tributary stream.

Ten years later, in February 2000, the situation has changed considerably, particularly among the Punan Tubu in Respen Sembuak, but also among those in Long Loreh and Kuala Ran. I will return to this below.

\subsection{The Merap}

Contrary to the Punan, the Merap have always had a strong sense of territoriality. When they talk today about their customary land, this is nothing new. They have had a strong sense of the borders of their area, and, with the help of allied groups of Punan, they have defended it and its resources, such as bird nest caves, good farming land, and large tracts of forests with commercially valuable NTFPs, such as damar, rattan, and eaglewood. It is not surprising that the Merap of Langap have old documents, even maps, that indicate their rights to the land. Other groups (Pua', Kenyah, some Punan), who more recently have settled within the 


\section{Recent Trends and Perspectives}

area recognized as Merap territory, have always asked for permission. The various Kenyah groups did so before they moved to the Malinau area in the 1960s and 1970s. This is also true for the Punan and Merap who moved from the Tubu to Kuala Ran in the 1970s.

The majority of the Punan groups living within the area recognized by the Merap as their customary land - i.e., the Malinau River and its tributaries from Gong Solok upstream - are sometimes, and for good reasons, recognized as Punan Bau or Punan Merap. ${ }^{42}$ They have been affiliated to the Merap since the first decades of the $19^{\text {th }}$ century, and that may be sufficient reason for labelling them as 'Punan Merap', but as we have seen, there's more to it than that. Most of these Punan, if not all of them, arrived in the Malinau watershed with the Merap. Each Punan band, which moved to the Malinau area as an ally of the Merap, inhabited and guarded a particular section of the territory conquered and controlled by the Merap. But what did the Punan groups gain from their association with the Merap? This question can be explained in economic terms: In exchange for the political subservience and economic contribution (NTFPs) of the Punan, the Merap brought them the trade items that they could not get by themselves, such as iron and tobacco. The Merap's chiefs were their Punan's toke, their bosses.

Concerning land rights, we can thus contrast two different types: formal rights on the upper Malinau were held by the Merap - it was part of their territory; the Punan Malinau never cared to challenge that formal right, but they did use that territory for subsistence. As for NTFPs, they collected them on behalf (or to the benefit) of the Merap, the formal owners. This changed, however, when the Punan were granted village land (wilayah desa). In this second type of land rights, an area was carved from the territory traditionally owned by the Merap. This, of course, was something that the Merap resented. The Merap, therefore, needed to reassert their overlordship of the whole Malinau basin by translating their traditional territorial ownership in terms of customary rights and political influence; otherwise, the sparsely populated upper half of the Malinau River would be Punan territory, while the Merap's territory would be restricted to a small and more densely populated - and increasingly contested - middle part of the Malinau River. 


\section{Recent Trends and Perspectives}

The Merap's political overlordship in the Malinau area has been increasingly challenged by the dynamic and well-organized Kenyah, ever since the various Kenyah groups settled in the Malinau in 1960s and 1970s. In the last decade, however, the political strength of the Merap has also weakened considerably in relationship to the Punan, especially the Punan Tubu in Kuala Ran, Long Loreh, and Respen Sembuak. These Punan now openly question the authority of the Merap leaders; they also make their own claims for land and reinterpret the whole history in order to make these claims politically legitimate. The creation of their own NGO, the Yayasan Adat Punan, the interest and support of politically more experienced NGOs, like PLASMA, and, last but not least, the fall of President Suharto and the reformasi of an old, authoritarian government, has considerably strengthened and encouraged a more selfassured attitude among the Punan Tubu. Previous overlords, like the Merap, are now criticized in a self-assured and outspoken way, which was impossible before May 1998 and the fall of the 'ancient regime'.

In 1990, it was fairly common for various Punan to point out that the Merap had always been dependent upon the support of the Punan. They 'would not have managed on their own', they would not have survived, so 'wherever there were Merap, there also had to be Punan'. These were common statements among Punan in the upper Malinau. This was, however, not a particularly controversial statement, as even Merap leaders admitted that this was the case: 'Punan were our soldiers, our army' (B.I., tentara); without them, 'the Merap would have been finished'.

\subsubsection{Territory and landscape}

Individual groups of Punan have not regarded their respective areas as their private property. One reason is that they have not had the economic reasons to do so, as I have suggested above. There has been very little competition. Also, they have been living within the area of a leading group of agriculturalists, e.g., the Merap in the Malinau area. Therefore, to say that the Punan's sense of territoriality has been weak or vague is one thing; to say that they have no sense of belonging to a certain tract of land is another. 


\section{Recent Trends and Perspectives}

Locality plays an important role in the way in which local people have identified themselves. It is common that they, in certain contexts, describe themselves as 'the people upriver'. The word 'Dayak', a collective term for all indigenous, non-Muslim peoples of Borneo, was introduced by Europeans and was previously unknown in central Borneo (Rousseau 1990: 12). The same is true for a number of ethnonyms used today. 'Dayak' has the meaning of 'towards the interior', or 'upstream' (Adelaar 1997), and the same applies to a number of ethnonyms used by various groups of Dayaks (e.g., Lun Daye, Murut).

The various peoples of Central Borneo have, as Rousseau has pointed out, 'identified themselves in geographical terms (the people of the river X)' (1990: 11). A large number of ethnic names, therefore, refer to particular rivers or localities, such as Kayan, Merap, Putuk, and so on. In distinguishing among the various groups of hunter-gatherers, the general ethnonym - Punan or Penan - has been followed by an autonym, referring to a particular place, usually a river - e.g., Punan Metut, Punan Halanga. When Punan themselves talk to each other, they seldom refer to each other as Punan. Instead they label themselves and others with reference to particular places, e.g., ' $a$ ' Metut'(B.P., Metut people), or 'orang Metut' (B.I., Metut people), or 'kami dari Metut' (B.I., we are from Metut).

Another aspect of landscape and locality that I would like to mention here concerns what James Fox (1997: 1) has talked about as 'ways in which social knowledge is framed and vested in particular landscapes'. Peter Brosius has also pointed out the importance of this. In one of his articles on the Penan Gang, a group of Western Penan in Sarawak, he describes their detailed knowledge of the forest landscape in which they live (1986). This knowledge is not much different from the knowledge of the Punan Malinau. Like the Western Penan, they do have a very detailed knowledge of 'the relative size of rivers, the angle of flow of one river to another, the topography between particular rivers, the proximity of headwaters of different rivers, and so forth' (Brosius 1989). This kind of detailed knowledge is perhaps not particularly surprising, as this is the landscape in which they live and make a living. This kind of detailed knowledge can therefore also be found among representatives 


\section{Recent Trends and Perspectives}

of other groups of Dayaks, in so far as they spend as much time in the forest and move around as much as many Punan/Penan do. However, this knowledge of the landscape also entails names given to various parts and features of this landscape. Brosius recorded some 2000 such names among the Western Penan. What is so important with these names is that they often contain geographical, ecological, genealogical, historical, or mythological information of some kind. In this way, socially important information is stored in and imprinted onto the landscape. The landscape therefore, according to Brosius, becomes a 'reservoir of detailed ecological knowledge and a repository for the memory of past events' (1986: 174-5).

It might be stated that this question concerning attachment to a particular 'landscape' is not unique to the Punan; it probably applies to any rural group in the world where there is a bond between the people and the land, through historical landmarks and ecological knowledge. The Punan case is therefore not unique, but it may be of special importance. The upriver settlements are very small and widely scattered, and this may give the impression that these areas are more or less uninhabited and therefore open for exploitation. My point is that these lands are not unoccupied or unused 'virgin' forests. First of all, these forests are more or less 'managed forests', something that can be recorded by botanical and ethno-biological research. These forests, however, also have a high 'cultural density' (Brosius 1997: 59), which is in most cases 'invisible', as it is carried in the consciousness of humans. This especially applies to the Punan, who, to a higher degree than other groups in the area, have been focused and dependent upon this vast forested landscape, economically and otherwise. A landscape is always more than mere geographical formations, it is also more than people's interactions with these formations. Landscapes as social phenomena are the result of the meanings and memories that people both invest in and draw from the geography they live in. In comparison to the Merap and other farming groups in the Malinau area, the Punan have left very few 'visible' traces on the landscape, besides fruit trees. This is, to some of them, seen as a dilemma today, as it makes it more difficult for them to rightful claim the rights to these vast tracts of land. Most traces 


\section{Recent Trends and Perspectives}

are simply not visible to outsiders and can only be read by the Punan themselves (cf. Section 4.2).

\subsubsection{Conservationists?}

The Punan have been utilizing plant and animal resources for centuries without degrading the environment. This, however, is not a consequence of a conservationist ideology, but is rather related to fact that the Punan have been rather few, scattered over a vast territory and equipped with limited technology. For the Malinau area as a whole, there has until recently been very limited demographic pressure on the natural resources. Hames defines conservation as a short-term restraint for long-term benefits (1987: 93), something that runs counter to the basic philosophy of immediate return and the Punan preference for spending rather than saving (Kaskija 1999b).

Considering the enormous size of the forest, the Punan have no reason to regard the environment - as western environmentalists clearly do - as fragile and in need of human protection and care. The Punan's relations with this environment are very pragmatic and contain few elements of what we call 'conservation'. If the Punan utilize certain (food) resources in a more restricted way, as a precaution against overexploitation, this is an act of economic rationality and has nothing to do with morality or the ideology of conservation. Rousseau says that the nomads of Borneo may protect their environment 'with regard to food resources, but not necessarily for items of trade' (1990: 234). Rousseau continues with reference to Borneo nomads:

'There has been excessive hunting of animals that may contain bezoar stones, rhinoceros are nearly extinct, many resinous trees have been overexploited, hornbills are endangered, and pigs are less numerous...; one must go further in the jungle to find rattan' (ibid.).

Compare also, for instance, Beavitt's description of Penan techniques for hunting hornbills to obtain feathers and the casque ivory:

'Penan, having observed a nest, shoot the male with a blowpipe dart, then fell the tree to obtain the female and the young' (Beavitt 1992: 186). 


\section{Recent Trends and Perspectives}

Punan lack ideological constraints on these kinds of activities, and, as long as it does not have any practical or economic consequences for them, they show very little concern about environmental degradation. What might be termed opportunism - a readiness to grab good opportunities whenever and wherever they appear, irrespective of the possible long-term consequences - is an important feature of Punan culture in general, much more important than any kind of eco-morality or 'feeling for nature' (cf. Kaskija 1999b).

During my fieldwork in the area in the early 1990s, I never heard any Punan express worries over the effects of logging, or even comment negatively on the situation in Sarawak, where several of them had witnessed the effects of large-scale deforestation. Instead, Sarawak always played the role of 'the land of opportunities' in local narratives. Woodburn's statement that 'those who consume most of their food on the day they obtain it and who are unconcerned about storage, also appear to be relatively unconcerned about conservation and about the planned development of their resources' (1980: 101), rings particularly true in the case of many Punan.

Today, the situation has changed, and many Punan - especially Punan Tubu - have adopted a new jargon, inspired by environmentalist arguments. Various NGOs working in the Malinau region have, among other things, expressed an interest in the ethno-biological knowledge of the local Punan. This interest has had an effect on the reflexive cultural and political consciousness of the local Punan, who have not only become the main providers of such information but, in meeting this demand, have also become increasingly aware of themselves as especially knowledgeable about the forest. I will return to this issue below.

\subsubsection{Return to Tubu}

As we have seen in Chapter 3 there are approximately 1400-1700 Punan in the Malinau/Tubu area who have not resettled to larger resettlement villages downriver. Depending on what will happen in the years to come, these Punan may become the real winners or losers in the present race 


\section{Recent Trends and Perspectives}

for land. These Punan are still residing in the vast, sparsely populated and still largely unexploited upriver areas to which they may claim special or exclusive rights. However, the most outspoken representatives are all living downstream today, whether in Long Loreh or Respen Sembuak.

Perhaps it is not surprising that there are plans among Punan Tubu today, both those in Respen Sembuak and those on the Ran River, to return to the Tubu River. There is increased competition for land, as well as the fact that they are disadvantaged because they have moved to resettlement areas downriver where they cannot claim special rights to the land - as they come from another area - and where there is a lack of good land. Returning to Tubu may give them the opportunity to claim land rights to a much larger area that may be used for their own subsistence, or - in case parts of the areas will be exploited by timber companies - which may give them substantial cash incomes through compensation. However - as Alang Lawing, former headman of Long Rat, pointed out - the Tubu area will attract only a limited number of people as long as there are no schools and no health services available upstream. If communication is made easier by the building of new roads (such as the logging road from Langap, which has now reached the Halanga River in upper Tubu), the movement of people to the Tubu area will most likely increase. The opening of a road will, however, not only lead to a movement of Punan towards the Tubu, but also to all kinds of outsiders, the effect of which is important to take into consideration.

The idea of re-appropriating the traditional territory is not specific to the Punan, but is found among all groups having formerly lived in isolated upstream regions and having migrated downstream. They feel the need to be present, at least partly, on their territory, in order not to lose their rights. As Sellato has pointed out, the Leppo' Ke from Long Lat, who massively moved out to the Malinau, left three families at Apau Ping to preserve the status desa of Long Lat and maintain rights over their own territory of the upper Ngiam River (Sellato, pers. comm.). 


\subsection{ASSISTANCE, CHARITY, AID AND COMPENSATION}

As has been mentioned earlier in this report, many Punan see land as a potential source of cash income today, whether in the form of compensation or as a source of aid of some kind. They frequently talk about bantuan (aid, help, assistance) and expect and hope that companies that start working in their areas help them economically, or give them material support in some form. Until recently assistance has been offered them through the Catholic mission, but especially through the Indonesian government in the form of an annual village aid (BanDes) and other forms of aid (e.g., Inpres Desa Tertinggal).

Ten years ago the Punan Malinau often talked about the situation in Sarawak. They pointed out that there were many logging camps in Sarawak and that the wages paid there were very good. Development had reached even the most distant villages; in Sarawak they were all modern. The Punan Malinau often pointed out that Bruno Manser - a Swiss artist who for seven years at the end of the 1980s stayed illegally among nomadic Penan, and who drew much media attention to their plight - helped the Sarawak Penan and saw to it that they received compensation money from local timber companies, which has enabled them to build modern villages and buy a lot of modern things. This means that many Punan in the Malinau area envied the Sarawak Penan and many of them often asked me why there were so few logging companies in the Malinau area. Logging companies were thus not seen as a threat in 1990-92. Although the concept of compensation has gained new meaning with the establishment of the coalmining company in Long Loreh, it was also very much in use 10 years ago, but in reference to the situation in Sarawak. The presence of wealthy logging companies was perceived not only as something that increases the opportunities for cash income through wage labour, but also as something that opens up possibilities for compensation and aid to local communities.

The appearance of the mining company in Loreh has been crucial. The payment of compensation, in cash and kind, to local communities has shaped local perceptions of land, not least because of an increase in 


\section{Recent Trends and Perspectives}

the value of land. It is not surprising that conflicts between villages have intensified, especially in the area affected by the mining company (Loreh, Langap, and Tanjung Nanga). Individual households in this area have established cash crop plantations, as a means to create privately owned pieces of land, especially in areas that most likely will be exploited by the mining company. Through local NGOs like PLASMA, the Punan and other groups also receive news from other parts of East Kalimantan, where local groups have received large sums of money in compensation. In some cases local communities in East Kalimantan have received, or at least demanded, several billion rupiah.

The village of Long Loreh received a compensation package from the mining company that included a truck that was intended for use by the village cooperative as a means of transporting people and agricultural equipment and produce between the village and the swidden fields along the road. This truck seems to be useful to the community as a whole. Another village, Nanuk Tanah Kibang (a mixed Punan-Merap village at Kuala Ran), received between 260 million and 400 million rupiah (according to different sources), in compensation from the coalmining company in 1999. This money was quickly spent, although not necessarily wisely so.

So far, compensation to local communities in the Malinau area has been exceedingly unfair and inconsistent, if not altogether unpredictable. The Punan settlements in the upper Malinau, on the Hong and Ran rivers, which are affected by logging and the construction of logging roads, have not received any compensation so far. This applies especially to the Punan hamlets in Long Uli, Long Metut, and Liu Mutai, as well as to the various groups of Punan along the Hong River (Punan Lake, Punan Halanga) and the Ran River (Punan Mirau, Punan Halanga, Punan Long Rat). As these Punan groups have not received any compensation or assistance from encroaching (logging) companies, their expectations are, therefore, not the same as those living in the vicinity of the coalmining company.

When the customary land of indigenous peoples is damaged in the process of logging, mining, or the construction of infrastructure, it is normally considered legitimate for the people to claim compensation, in 
cash or kind. Without questioning the legitimacy of these claims, I still find the question of compensation quite problematical.

The possibilities for economic compensation - such as in the area around the coalmining company in Long Loreh - do affect people's choices and strategies. By opening up a swidden or by planting perennial crops in an area that is expected to become the next target for exploitation, individual households make claims to particular plots of land that, irrespective of their agricultural potential, may become generators of compensation money. Might such strategies cast increasing doubts on the legitimacy of people's claims? What are the effects on local communities when such strategies are increasingly individualized? Can money compensate for the loss of land? In general, compensation seems to cause lots of rifts within societies, lots of fighting and bitterness. Those who should gain, get nothing; while those who should not gain sometimes get a lot. How to balance compensation for a durative infringement (like a permanent loss of land) to living individuals against a collective of yet unborn future injured parties? How to balance the economic loss against the cultural loss? Can it ever be just?

\subsection{CULTURAL REFLEXIVITY}

During the 1990s a number of researchers, photographers, and also a growing number of $\mathrm{NGOs}^{43}$ — such as WWF and PLASMA - have visited the Malinau area and the Punan. Many of these visitors have shown a particular interest in the culture and the knowledge of the Punan, so these contacts have also stimulated and created a growing awareness locally of the political value of their own culture and knowledge of the forest. Demonstrating knowledge of the forest can thus be something of political significance to the local Punan. Many of these new outsiders have been particularly interested in the documentation of culture and traditional knowledge, but also in acting as a sort of mediator and to give support to the local communities in their interaction with companies and other outsiders with commercial interests. All this has had an effect on the reflexive cultural and political 


\section{Recent Trends and Perspectives}

consciousness of the Punan. The concept of culture has increasingly, also among the Punan in the Malinau/Tubu area, become politicised. However, the use of 'culture' and cultural identity for political purposes - e.g. to achieve political legitimacy when it comes to territorial rights — is a very recent phenomenon in the Malinau area.

Ten years ago most Punan were rather puzzled by the interest shown by western visitors, such as myself, towards their knowledge of the forest. When asked about medicinal plants, many of them would rather point out that they use modern medicines today, as a way to escape being labelled 'primitive'. Being a forest dweller and forest expert was, 10 years ago, not normally a reason for pride, but rather something characteristic of anak buah and other low-status groups, classified by the Indonesian administration as 'isolated tribes' (B.I., suku-suku terasing) and 'not yet modern' (B.I., belum maju). Anything that was a characteristic of the Punan was often, at that time, a reason for concealment.

To say that the Punan previously did not reflect upon their own culture is, therefore, not true. The Punan have long been aware of the norms and values of the surrounding societies and the representatives of the Indonesian state. The Punan have, as far as possible, tried to present themselves in a way that was to their own advantage and that increased their opportunities and reduced the risk of conflicts. They have thus tried to conceal such aspects that neighbours or state representatives have despised. This has been a reason for them to, if not so much reflect on who they are, at least try to manage and influence the way they have been perceived by others. This reflexive feature is related to their stigmatised identity. Today, however, the Punan - at least the Punan Tubu - are beginning to explore and discover their own 'cultural uniqueness', which they are increasingly exploiting for political purposes. Claiming a unique culture is now a way to achieve political legitimacy in a new context of growing competition for land and the increased presence of local, national, and international NGOs.

The invention or revitalization of 'traditional' culture serves, in the context of the Punan Malinau/Tubu, as 1) a means of self-identification, 2) a political tool; and, 3) a commercial asset, meant to draw profit from 


\section{Recent Trends and Perspectives}

tourism (cf. tourist destinations, cultural festivals, handicrafts), from NGOs (cf. traditional ecological knowledge, endangered minority culture), and other agencies. The question of 'culture' as an economic asset can be compared to the discussion of opportunism in my previous CIFOR report (Kaskija 1999b).

\subsection{GROWING POLITICAL AWARENESS}

Until recently, the Punan have been, socially and politically, exceptionally weak and fragmented in comparison to their farming neighbours. They have not had any organization on the level of the ethnic group. However, in 1994 the Punan Tubu from Respen Sembuak founded their own NGO, the Yayasan Adat Punan (YAP). The founding of this Punan NGO occurred in a context of expanding political awareness, where lobbying for recognition and funds, from governmental or non-governmental organizations, is important. In June of the same year this NGO organized a 'Punan Festival', which was attended by a large number of Punan, some of them from other parts of East Kalimantan. For the first time, Punan groups that had never before come together became aware of common interests. The first steps toward a more complex 'multi-Punan' identity and the emergence of a more encompassing category of selfidentification appear to have been taken. So, YAP could be seen as a kind of new 'imagined' collective identity, as it includes not only local Punan groups, but all groups of Punan in East Kalimantan. Previously, these various groups had nothing in common, whether linguistically, culturally, or otherwise, so, it is fair to say that they are now becoming culturally more and more self-conscious and more organized.

The process whereby a people make use of their own cultural resources, 'reaching into their roots' (Lee 1988: 183), has been characterized as a kind of cultural revitalization. What is interesting, in the context of the Punan Tubu, is that this kind of revitalization takes much of its form from the highly folklorised perception of local cultures common in Indonesia. This was especially the case with the Punan Festival held in Respen Sembuak in 1994. It was also something to be seen in 


\section{Recent Trends and Perspectives}

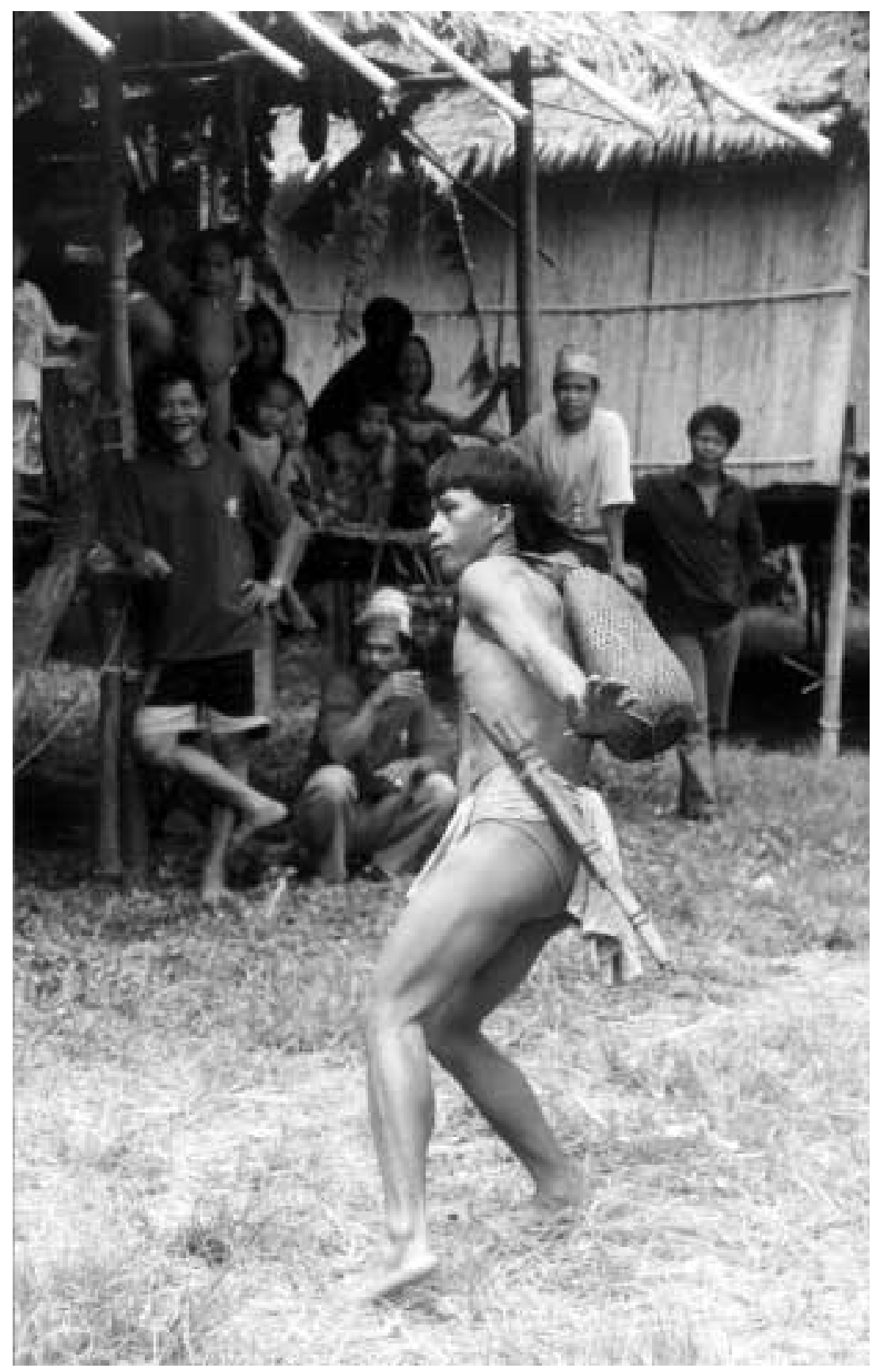

Numerous visitors to the area stimulated a growing awareness of the political issue of their own culture among the Punan 


\section{Recent Trends and Perspectives}

Long Mirau in February 2000, where Alang Lawing (former headman of Long Rat), inspired by the 1994 Punan Festival, was planning his own festival for the local Punan and representatives of the local timber company. Preparations for this festival included a number of 'traditional Punan glasses', i.e., drinking vessels made of bamboo that were to be used to the amusement of the timber company employees. This was something that would not have occurred 10 years ago. Today these bamboo glasses are perceived not as something that would confirm an already stigmatised, primitive identity, but as something that would rather confer on them an aura of cultural uniqueness.

Like many other groups of former or present hunters and gatherers, the Punan have never tried to formalize or codify their own 'culture' or even to think about themselves in terms of 'a culture' (cf. Kaskija 1999b). The current 'objectification' of everyday life as 'culture', whereby an increasing number of Punan (Tubu) have become aware of having a 'culture' and what characterizes this culture, is, therefore, a new phenomenon. To these Punan (Tubu) today, it is obvious that 'culture' is an important resource that can be used in negotiations with various outside parties, such as national and international agencies.

Although this kind of process is still weakly developed among the Punan of the Malinau/Tubu area, as compared to indigenous peoples in many other parts of the world, it is nonetheless obvious that individual Punan Tubu, like Alang Lawing, are trying to make the 'traditional' relevant in a new context - something that has been described as the 'invention of culture'. Many anthropologists talk about 'invented culture', or about the 'essentialization' or the 'reification' of cultures (cf. Sahlins 1999: 402). Although this process is still in its initial stage in the Malinau/Tubu area, it is increasingly finding open expression, especially through the local NGO, Yayasan Adat Punan, and among people living in Respen Sembuak.

As Keesing and others have pointed out, the leaders of modern movements of cultural revival are often the most acculturated people (Sahlins 1994: 390). This is also true for the Punan in the Malinau/Tubu area. Some of the new leaders in Respen Sembuak are not only the most well-educated Punan, with the most experience of modern settings, they 


\section{Recent Trends and Perspectives}

have also been living, for the most part of their lives, in downriver, multiethnic villages or in cities. Education and a thorough acquaintance with the government administration and the political language and codes of the modern Indonesian state are prerequisites for a successful defence and promotion of a political cause.

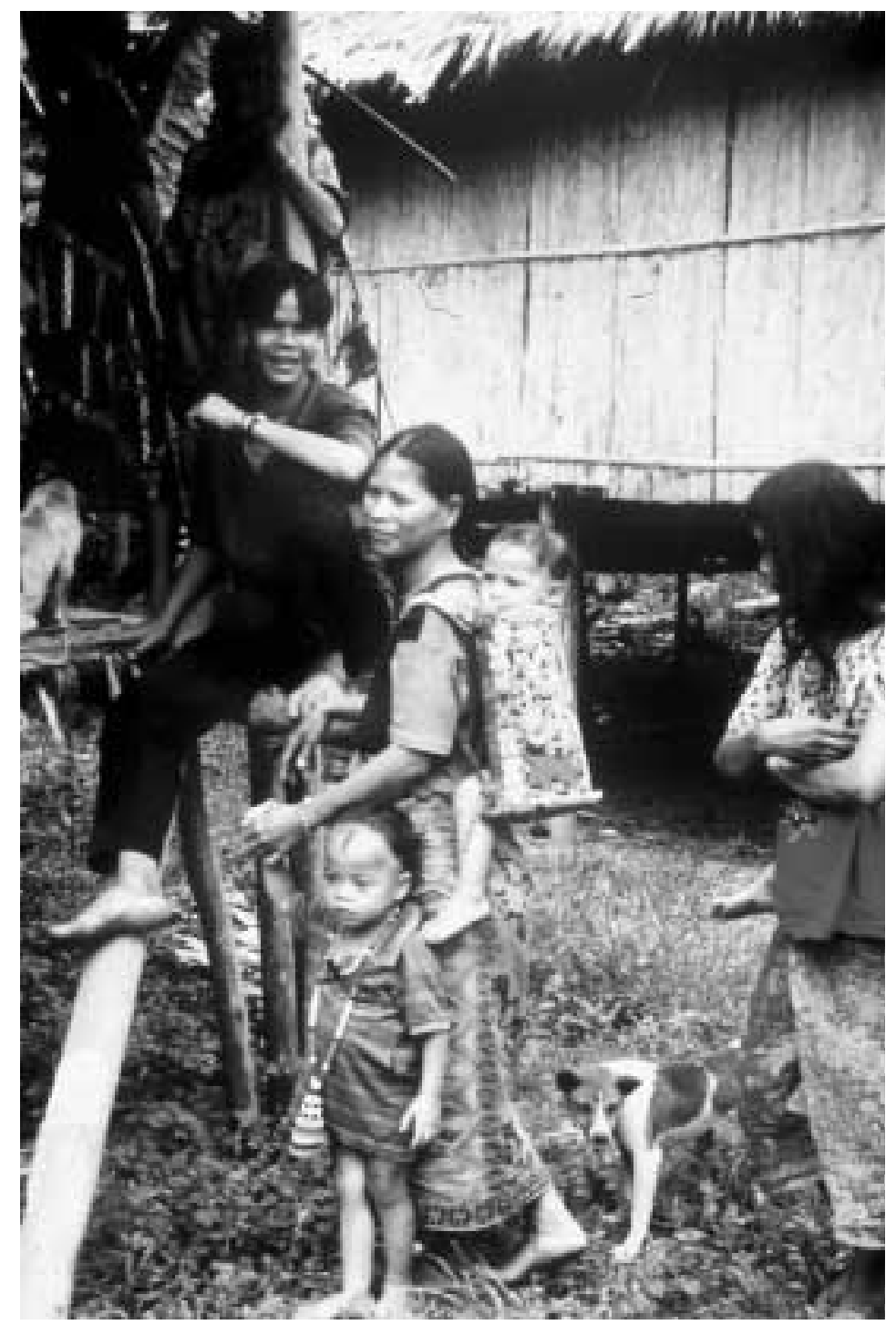

Celebration of a new rice harvest, Long Nyau, upper Tubu 


\section{Endnotes}

${ }^{1}$ According to Rousseau, there are approximately 39,000 'Kelabitic Murut', a category of people that includes Lun Daye, Sabah, Lun Bawang, Merau (or Berau, Seben), Milau, Nyibun, Putuk (or Potok), and Tring (1990: 19).

${ }^{2}$ Words in the Punan language are indicated by B.P. (bahasa Punan), to distinguish them from words in Indonesian (B.I.).

${ }^{3}$ The discrepancy between the 1989 and 1990 figures are striking. I have no explanation, but it seems very unlikely that this Punan group nearly quadrupled in a single year.

${ }^{4}$ In the Tubu area there are 450-500 Punan who also belong to this category of Punan 'who have not resettled downriver' or taken up residence in resettlement villages. In the Bengalun and Gong Solok there were, according to official statistics, an additional 160 (in 1989) or 338 individuals (in 1990), which means that the total number of Punan who have not resettled to larger resettlement villages amounts to at least 1400 individuals in the Malinau-Tubu area, but may include as many as 1700 . ${ }^{5}$ According to Ncau Usat - an old Punan Metut man from Long Uli this man, Utan Pilak, joined the Merap going from Tubu to the Malinau some 200 years ago. According to this version, Utan Pilak was probably not a forefather to the Punan Halanga. 


\section{ENDNOTES}

${ }^{6}$ For an explanation of mufut, see section 5.2.1.

${ }^{7}$ Eaglewood, locally known as gaharu, is a 'pathologically diseased portion of several different species of trees of the genus Aquilaria. When burned, this wood gives off a rather pungent fragrance, and thus it has been used as incense by Chinese, Indians, and Arabs' (Hoffman 1984: 137; cf. De Beer \& MacDermott 1989).

${ }^{8}$ Punan today increasingly hunt with shotguns - if there are cartridges available. These cartridges are, however, very expensive, approx. Rp. 20-25,000 each.

${ }^{9}$ Illipe nuts, locally known as tenkawang, are nuts with a high fat content. These nuts are produced by several species of Dipterocarp trees.

${ }^{10}$ Bila' Bekayuk is a Punan Tubu village that resettled from upper Tubu to Long Loreh in the early 1970s.

${ }^{11}$ Long Kubaa is an old Merap (or Ngurik) village site in the upper Malinau, situated between the Mekayan and Menureh rivers.

${ }^{12}$ According to Bare' Tangga', these mountains were known as Tukuk Kelempit and Tukuk Umaluit.

${ }^{13}$ The meaning of anak buah is complex and depends on context; it can denote that someone is a follower, a client, a dependent, a vassal, a supporter of some kind, an employee, a sharecropper, a retainer, or a servant. It is based on the metaphor of the family, i.e., a group of people headed by a father (a patron or bapak) who takes care of and is supported by his children (anak, anak buah).

${ }^{14}$ This information is partly based on the Merap's own handwritten documents, transcribed and/or translated by myself or Puri (2000), supplemented by field interviews and written sources (Sellato 1995a, 1995b). See also Appendix 3.

${ }^{15}$ This group left the Lurah at approximately the same time as the Merap (Berap), and for the same reasons. However, while the Merap went to the Malinau/Tubu, the Tembau - or at least some of them - went up the Bahau River and settled at Ka Tempu near Apau Ping (Sellato 1995a). It seems to be this location that has given them their ethnonym, Tembau (or Tempuu). Around 1850 they were at war with the Merap, but peaceful 


\section{ENDNOTES}

relations soon developed and, according to Sellato (ibid.), they moved to the Tubu around 1900 and settled among the Merap of Long Kendai and the Abai of Long Bila.

${ }^{16}$ They were settled at Liu Mutai - close to the Metut River - before moving to Seturan.

${ }^{17}$ Sellato (1995a) suggests that this split occurred around 1880-1900. I would suggest that it happened much earlier, around 1850-60. This split happened before the Merap (Lungu' Alang) established relations with Panembahan Raja Tua, which probably occurred for the first time in the 1860 s.

${ }^{18}$ Tabau Baung is situated between the Malinau and Hong rivers, at the headwaters of the Bengawat River (a tributary of the Malinau) and the Benuang River (a tributary of the Hong). The Merap village was not built on the top of, but below the mountain.

${ }^{19}$ According the Ncau Usat - an old Punan Metut man in Long Uli Punan Metut (i.e., the forefathers of the present-day Punan Metut) were the owners of the caves in Seturan and Rian after the Berusu' had left, although all profits from these caves were shared equally with the Merap. Later, however, the Merap cheated the Punan and managed to appropriate exclusive rights to the caves. Even though the Merap can present documents saying that they are the owners of the caves, they are not the original owners, Ncau Usat said.

${ }^{20}$ There is data suggesting that Ibung Alang was settled somewhere close to Kuala Ran before succeeding his older brother as chief of the 'main' Merap group, then living at Tabau Baung.

${ }^{21}$ This system of appointing regional, paramount chiefs, so-called 'raja besar' or 'kepala adat besar', was abolished by the Indonesian administration in the late 1980s. Despite this, the Langap Merap still consider their leader, Mpang Alang, to be a paramount chief of the Malinau area. ${ }^{22}$ In his first marriage, Alang Mpang married a Kenyah Uma' Kulit from Long Lejuh, Kayan. Her name was Paren. She was the mother of Mpang Alang, but she died early in the 1930s. Alang Mpang's second wife came from Langap (Urai Ncau). After divorcing her, Alang married 


\section{ENDNOTES}

Wing Ubang, a daughter of Ncau Alang, older brother of Alang's grandfather, Mpang Alang. Ncau Alang and Mpang Alang had the same father, Alang La'ing, but different mothers.

${ }^{23}$ The Punan Lurah who accompanied the Merap to the Malinau in the beginning of the 19th century were NOT related to the Punan Benalui, i.e., the present-day inhabitants of the Lurah area. Punan Benalui arrived in the Lurah at the end of the 19th century. The Punan Lurah who joined the Merap were a group of 'Punan Bahau', some of whom are now found on the Kayan, e.g., Punan Berun.

${ }^{24}$ According to Maring Ipu' - the old man in Long Jalan — the Punan Arah were moving back and forth between the upper Tubu and the Arah River before the arrival of the Merap.

${ }^{25}$ There may be one exception, A Punan band is mentioned that was labelled 'Punan Malinau River' and that was headed by a man named Uku Lawing. It is not, however, clear if he was a contemporary of the first Merap. All other Punan headmen who became the followers of the Merap in the beginning of the $19^{\text {th }}$ century were living in the Tubu area. ${ }^{26}$ Names of Punan headmen mentioned are: Kompoi Jalai (Punan Kalun), Uku Lepi (Punan Imam/Iman, Menabur, Tubu), Irang Ipu' (Punan Kalun), Anta Dengan or Hatah Lengan (Punan Kalun), Uku Lawing (Punan Malinau), Ibung Ula' (Punan Kenliung), Amu' Ilun (Punan Batu Antang), Toh Ilau (Punan Kalun), La'ing Batu (Punan Kalun), and La'ing Ajun (Punan Tubu). The locations Kenliung and Batu Antang are unknown to me, places that can be situated outside the Tubu area. It should also be noted that all these Punan headmen were not necessarily contemporaries. ${ }^{27}$ This document is entitled 'Riwayat yang Penjaga goha sarang burung Sungai Seturan dan Sungai Riyan. Di waktu riwayat Alang Incau dan Alang Empang' (Puri 2000). When this document was written, in the late 1950 s, one of the Punan who put his name as a witness to the document was Usat Kelit, whose daughter, Urai, married Rhomulis, Bila' Bekayuk Loreh.

${ }^{28}$ According to informants from Long Jalan, this man, To' Ilau, was a Punan from the Lurah River who accompanied the Merap to the Malinau/ Tubu area. Another informant, the Merap chief Mpang Alang, denied 


\section{ENDNOTES}

that and suggested instead that To' Ilau was the leader of the Punan Tanah Kibang on the Sengayan River. To' Ilau and Mpang Jalee lived at the same time as the Merap chief La'ing Lungu', i.e., in the latter part of the $19^{\text {th }}$ century. This statement is not supported by the genealogical data presented by Ncau Usat of Long Uli (see Appendix 8).

${ }^{29} \mathrm{Cf}$. page 32 .

${ }^{30}$ Kenawit refers to the Kanowit area of the Rejang in Sarawak. Kanowit is the homeland of the Beketan. As for the Mahakam, there is, even now, a group of Beketan at Muara Tubo' on the Belayan, a northern tributary of the Mahakam. Some of them indeed say they came from 'Mentarang' (Sellato, pers. comm.).

${ }^{31}$ The term sebila' is often used to refer to blood brotherhood among the various ethnic groups in the area.

${ }^{32}$ Oyang Maring and his followers are the so-called Punan Liu Mahan, who would later settle with the Kenyah Leppo' Ke in Long Loreh.

${ }^{33}$ The existence of birdnest caves in the Malinau may have originally attracted the Kayan to the region.

${ }^{34}$ Not all of them are Kenyah. Nyibun (in Gong Solok) and Pua' (in Tanjung Nanga) are included in the Kenyah category here, as they have many features in common with the Kenyah, and they all (except Leppo' Kuda) arrived in the Malinau from the mid-1960s onwards. They are thus late arrivals to the Malinau area.

${ }_{35}$ Punan themselves translate the word mufut as 'berpindah-pindah' (B.I., to keep moving from place to place, to change place of residence regularly).

${ }^{36}$ The Punan have no word that directly corresponds to the Indonesian keluarga, which is translated as 'family'.

${ }^{37} \mathrm{KK}$ (kepala keluarga) in the Indonesian administrative jargon refers to 'nuclear family', which bufut was probably not. Possibly, nuclear families now go mufut on their own, not in larger kin groups as in the truly nomadic past (Sellato, pers. comm.). 


\section{ENDNOTES}

${ }^{38}$ This may sound like a contradiction, as mufut would probably have been the 'routine' in the past, before the Punan started to make villages. However, during the decades prior to the coming of the Dutch, the Punan Malinau did not live in villages but still practiced some cultivation and therefore remained for some time in a particular location. After awhile, however, 'We got tired of eating cassava and went mufut again', as one informant expressed it.

${ }^{39}$ The Ngurik left the Malinau area approximately 150 years ago. We do not really know what they were like at that time, but it seems likely that, in terms of stratification, they resembled other groups in the region, such as the Abai. Intermarriages between Punan and Ngurik were not uncommon, which is indicated by genealogical data and by such statements by Punan as: 'There are no Ngurik left today [in the Malinau area], only blood'.

${ }^{40}$ The price for a $5 \mathrm{hp}$ long-tailed boat engine in 1991 was Rp. 600,000. In February 2000 the price was Rp. 2,500,000.

${ }^{41}$ Pre-1989 title awarded to a male holder of a five-year tertiary degree. ${ }^{42}$ Punan in Bengalun and Gong Solok, i.e., the Punan Berusu', characterize the Punan along the Malinau River as 'Punan Bau', i.e., Punan Merap. There are also written sources using the ethnonym 'Punan Merap' (e.g., Wurm and Hattori 1981).

${ }^{43}$ There are at least 10 different NGOs that have visited the Malinau area in recent years: PLASMA, SHK (Konsorsium System Hutan Kemasyarakatan), BIOMA (Biosfer Manusia), Yayasan Tanah Merdeka (from Sulawesi), INSIS , LPMA(Lembaga Pembinaan Masyarakat Adat, from South Kalimantan), PPSDAK (Pembinaan Pengelolaan Sumber Daya Alam Kemasyarakatan, from West Kalimantan), Yayasan Padi (Dayak organization from Pasir, East Kalimantan), WWF (World Wide Fund for Nature) and, finally, YAP (Yayasan Adat Punan). 


\section{Bibliography}

Adelaar, K.A. 1997. An Exploration of Directional Systems in West Indonesia and Madagascar. In: G. Senft (ed). Referring to Space: Studies in Austronesian and Papuan Languages. Oxford University Press.

Aspinall, R. 1990. Sarawak: The human consequences of logging. Cultural Survival Quarterly 14(4): 71-73.

Babcock, T.G. 1974. Indigenous Ethnicity in Sarawak. Sarawak Museum Journal 22(43): 191-202.

Beavitt, P. 1992. Exotic animal products and Chinese trade with Borneo. Anthropozoologica 16: 181-88.

Brosius, J.P. 1986. River, Forest and Mountain: The Penan Gang Landscape. Sarawak Museum Journal 36(57): 173-184.

Brosius, J.P. 1988. A Separate Reality: Comments on Hoffman's the Punan: Hunters and Gatherers of Borneo. Borneo Research Bulletin 20: 81-106.

Brosius, J.P. 1989. Landscape and Society in Borneo: Penan HunterGatherers of Sarawak. Rainforest: Life in a Canopied World. The University Museum of Archaeology and Anthropology, University of Pennsylvania.

Brosius, J.P.1997. Endangered Forest, Endangered People: Environmentalist Representations of Indigenous Knowledge. Human Ecology. 25: 47. 


\section{BIBLIOGRAPHY}

Chen, P.C.Y. 1990. Penans. The Nomads of Sarawak. Pelanduk Publications, Malaysia.

Chin, S.C. 1985. Agriculture and Resource Utilization in a Lowland Rainforest Kenyah Community. Sarawak Museum Journal 35 (56, Special Monograph, No. 4).

Crain, J.B. 1978. The Lun Dayeh. In: V. T. King (ed.). Essays on Borneo Societies, 123-42. Oxford University Press, Oxford.

De Beer, J.H., and MacDermott, M.J. 1989. The Economic Value of Non-Timber Forest Products in Southeast Asia, with emphasis on Indonesia, Malaysia and Thailand. Netherlands Committee for IUCN, DAMRAK 28-30, NL-1012 L.J., Amsterdam.

Fox, J.J. 1997 Place and Landscape in Comparative Austronesian Perspective. In: Fox, J.J. (ed.). The Poetic Power of Place. Comparative Perspectives on Austronesian Ideas of Locality, 1-21. Canberra: Department of Anthropology, Australian National University. Gillis, M. 1991. Economics, Ecology, and Ethnics: Mending the Broken Circle for Tropical Forests. In: Bormann, F.H. and Kellert, S.R. (eds.) Ecology, Economics, Ethnics: The Broken Circle. New Haven and Yale University Press. London.

Gómez González, I.C. 1999. Indigenous Management of Forest Resources in East Kalimantan, Indonesia. The Role of Secondary Forests. Master's thesis. Wageningen Agricultural University.

Hames, R. 1987. Game Conservation of Efficient Hunting. In: McCay, B.J. and Acheson, J.M. (eds.). The Question of the Commons: the Culture and Ecology of Communal Resources, 92-107. University of Arizona Press. Tucson.

Harrisson, T. 1975. Further Notes on Sarawak and Kalimantan Punan (and Penan). Borneo Research Bulletin 7: 3-4.

Harrisson, T. 1986. World Within: Borneo Story. Oxford University Press. Hastrup, K., and Olwig, K.F. 1997. Siting Culture. Routledge.

Hoffman, C. 1983. Punan. Ph.D thesis. University of Pennsylvania.

Hoffman, C. 1984. Punan Foragers in the Trading Networks of Southeast Asia. In: Schrire, C. (ed.). Past and Present in Hunter Gatherers Studies, 123-149. Academic Press, Orlando. 


\section{BIBLIOGRAPHY}

Hviding, E. 1993. Indigenous Essentialism? 'Simplifying' Customary Land Ownership in New Georgia, Solomon Islands. Bijdragen tot de Taal, Land-en Volkenkunde 131(4).

Hylland, E. T. 1997. Multiculturalism, Individualism and Human Rights. In: Wilson, R. (ed.). Human Rights, Culture and Context. Pluto Press. London.

Kaskija, L. 1999a . The Punan of Borneo: Cultural Fluidity and Persistency in a Forest People. In: Hornborg, A. and Kurkiala, M. (eds.). Voices of the Land: Identity and Ecology in the Margins. Lund Studies in Human Ecology (1). Lund University Press. Lund

Kaskija, L. 1999b. Stuck at the Bottom: Opportunity Structures and Punan Malinau Identity. CIFOR. Bogor, Indonesia.

Katz, E. 1997. NWFPs in Bulungan, East Kalimantan, Indonesia. In: Mittelman, A.J., Lai, C.K., Byron, N., Michon, G., and Katz, E. (eds.). Non-Wood Forest Products. Outlook Study for Asia and the Pacific: Towards 2010, 39-46. Working Paper no. APFSOS/WP/28. Bangkok: FAO, Forestry Policy and Planning Division, Rome/Regional Office for Asia and the Pacific. Bangkok.

Knapen, H. 1998. Lethal Diseases in the History of Borneo: Mortality and the Interplay between Disease Environment and Human Geography. In: King, V.T. (ed.). Environmental Challenges in South East Asia, 69-94. Curzon Press, Richmond, Surrey.

Lee, R.B. 1988. The Impact of Development on Foraging Peoples: A World Survey. In: Bodley, J.F. (ed.). Tribal Peoples and Development Issues. A Global Overview. Mayfield Publ. Co., Mountain View, California.

Lowenhaupt-Tsing, A. 1993 In the Realm of the Diamond Queen. Princeton Univ. Press. Princeton.

Levang, P. et al. 2002. People's Dependencies on Forests. In: Technical Report, Phase 1, 1997-2001. ITTO Project PD 12/97, Rev. 1 (F), Forest, Science and Sustainability: The Bulungan Model Forest. ITTO, CIFOR, MOF. Bogor, Indonesia.

Metcalf, P. 1974. The Baram District: A Survey of Kenyah, Kayan and Penan Peoples. Sarawak Museum Journal 22(43): 29-41. 


\section{BIBLIOGRAPHY}

Needham, R. 1964. Blood, Thunder and Mockery of Animals. Sociologus 14(2).

Nicolaisen, J. 1974/75. The Negritos of Casiguran Bay. Problems of

Affluency, Territoriality and Human Aggressiveness in Hunting Societies of Southeast Asia. Folk 16-17.

Nicolaisen, I. 1986. Pride and Progress: Kajang Response to Economic

Change. Sarawak Museum Journal 36(57): 75-116.

Njau Anau 1999. Laporan studi pengamatan partisipatif di desa Langap,

Paya Seturan, dan Tanjung Nanga, Kecamatan Malinau. CIFOR. Bogor, Indonesia.

Ovesen, J. 1993. Anthropological Reconnaissance in Central Laos. A Survey of Local Communities in a Hydropower Project Area. Uppsala: White Lotus Press.

Padan, S. and Laway, Y.B. 1999. Laporan survey kawasan desa di hulu DAS Malinau, Kecamatan Malinau (19 Pebruari s/d 4 Maret 1999). Tanjung Selor. CIFOR, WWF \& PLASMA.

Posey, D. A., and Graham, D.1996. Beyond Intellectual Property. Toward Traditional Resource Rights for Indigenous Peoples and Local Communities. International Development Research Centre, Ottawa. Puri, R.K. 2000. The Story of the Guarding of the Birdsnests Caves at Sungai Seturan and Sungai Riyan during the Tale of Alang Incau and Alang Empang. Translation of Merap document from 1958-1963.

Puri, R.K. 2001. Bulungan Ethnobiology Handbook. Bogor: CIFOR, Prosea, East-West Center. Bogor, Indonesia.

Rousseau, J. 1974. The Baluy Area. Sarawak Museum Journal 22(43): $17-27$.

Rousseau, J. 1988. Central Borneo. A Bibliography. Special Monograph, Sarawak Museum Journal.

Rousseau, J. 1990. Central Borneo. Ethnic Identity and Social Life in a Stratified Society. Clarendon Press. Oxford.

Sahlins, M. 1994. Goodbye to Tristes Tropes: Ethnography in the Context of Modern World History. In: Borofsky, R. (ed.). Assessing Cultural Anthropology, 377-94. McGraw-Hill, New York.

Sahlins, M. 1999. Two or three things that I know about culture. Journal of the Royal Anthropological Institute 5(3): 399-421. 
Sather, C. 1995. Sea Nomads and Rainforest Hunter-gatherers: Foraging Adaptations in the Indo-Malaysian Archipelago. In: Bellwood, P., Fox, J.J. and Tryon, D. (eds). The Austronesians, 229-68. Department of Anthropology, Research School of Pacific and Asian Studies, The Australian National University. Canberra.

Schneeberger, W.F. 1979. Contributions to the Ethnography of Central Northeast Borneo (parts of Kalimantan, Sarawak and Sabah). University of Berne, Institute of Ethnology. Berne.

Sellato, B. 1988. The Nomads of Borneo: Hoffman and Devolution. Borneo Research Bulletin 20(2): 106-120.

Sellato, B. 1994. Nomads of the Borneo Rainforest. The Economics, Politics, and Ideology of Settling Down. University of Hawaii Press. Honolulu.

Sellato, B. 1995a. The Ngorek: a survey of Lithic and Megalithic Traditions in the Bahau Area, East Kalimantan, and an Interdisciplinary Sketch of Regional History. Culture and Conservation Programme. World Wide Fund for Nature Indonesia Programme. Jakarta.

Sellato, B. 1995b. Agricultural Practices, Social Organization, Settlement Patterns, and Ethnogenetic Processes in East Kalimantan. In: Sörensen, K.W. (ed.). People and Plants in Kayan Mentarang. Man and the Biosphere Series. UNESCO. Jakarta

Sellato, B. 1997. Agricultural Practices, Social Organization, Settlement Patterns, and Ethnogenetic Processes in East Kalimantan. In: Sörensen, K.W. and Morris, B. (eds.). People and Plants of Kayan Mentarang, 27-57. WWF \& UNESCO, London.

Sellato, B. 2000. L'ethnologue entre l'écologiste et le bon sauvage. De l'usage de la recherche en sciences humaines pour la praxis des ONGs et le développement durable. In: Bahuchet, S., Bley, D., Pagezy, H., Vernazza-Licht, N. (eds.). L'homme et la forêt tropicale, 89-98. Travaux de la Société d'Ecologie Humaine Series. Chateauneuf-deGrasse, Editions de Bergier, France.

Whittier, L., and Whittier, P.R. 1974. The Apo Kayan Area of East Kalimantan. Sarawak Museum Journal 22(43): 5-15.

Wollenberg, E. 1999. Incentives for Gaharu Collection in East Kalimantan. CIFOR. Bogor, Indonesia. 


\section{BIBLIOGRAPHY}

Woodburn, J. 1980. Hunters and Gatherers Today and Reconstruction of the Past. In: Gellner, (ed.) Soviet and Western Anthropology. Duckworth. London.

Wurm, S., and Shiro Hattori 1981. Language Atlas of the Pacific Area. Pacific Linguistic C-66. Canberra. 


\section{Appendices}

\section{Appendix 1. Population figures according to Padan and Laway (1999)}

\begin{tabular}{lcc}
\hline Village & Families & Population \\
\hline Long Uli & 32 & 119 \\
Long Metut & 8 & 35 \\
Long Keramu & 43 & 151 \\
Long Lake & 23 & 115 \\
Long Kirau & 20 & 83 \\
Long Jalan & 45 & 179 \\
\hline \multicolumn{1}{c}{ Total } & 171 & 682 \\
\hline
\end{tabular}

\begin{tabular}{llcc}
\hline Village & Ethnic group & Families & Population \\
\hline Kuala Ran & Punan, Merap & 56 & 248 \\
Laban Nyarit & Punan, Merap & 75 & 304 \\
Seturan & Punan, Merap, Lepo' Kuda & 121 & 640 \\
\hline & Total & 252 & 1192 \\
\hline
\end{tabular}

\begin{tabular}{llrc}
\hline Name of the location & $\begin{array}{l}\text { Ethnic } \\
\text { group }\end{array}$ & Families & Population \\
& Punan & 32 & 119 \\
\hline Long Uli (subdivision of Pelancau Loreh) & 8 & 35 \\
Long Metut (subdivision of Pelancau Loreh) & Punan & 43 & 151 \\
Long Keramu (subdivision of Pelancau Loreh) & Punan & 23 & 115 \\
Long Lake (subdivision of Lake Seturan) & Punan & 20 & 83 \\
Long Kirau (subdivision of Lake Seturan) & Punan & 126 & 503 \\
\hline
\end{tabular}

Population figures given by Samuel Padan (WWF) and Yusup Bit Laway (Plasma), who did a survey in the area in February 1999. 


\section{Appendix 2. Malinau District: Population and Ethnic Groups (1990)}

\begin{tabular}{|c|c|c|c|c|c|c|}
\hline VILLAGE & PUNAN & MERAP & PUTUK & KENYAH & ABAI & TOTAL \\
\hline \multicolumn{7}{|c|}{ Kota Malinau area } \\
\hline Tebuyau & 54 & & & & & 54 \\
\hline Lepaga & 65 & & & & & 65 \\
\hline Sebenuang & 52 & & & & & 52 \\
\hline Menabur Semido & 70 & & & & & 70 \\
\hline Semolon & 54 & & & & & 54 \\
\hline Long Agis & 127 & & & & & 127 \\
\hline Long Tarau & 84 & & & & & 84 \\
\hline Menabur Besar & 81 & & & & & 81 \\
\hline Menabur Kecil & 69 & & & & & 69 \\
\hline Mabung & 96 & & & & & 96 \\
\hline Long Nit & & & & & 120 & 120 \\
\hline Long Pangian & 105 & & & & & 105 \\
\hline Long Lihi & 78 & & & & & 78 \\
\hline Long Payang & 52 & & & & & 52 \\
\hline Long Kenday & & 94 & & & & 94 \\
\hline Paking & 39 & & 100 & & & 139 \\
\hline Pulau Sapi & & & 874 & & & 874 \\
\hline Lidung Keminci & & & 215 & & & 215 \\
\hline & 1026 & 94 & 1189 & 0 & 120 & 2429 \\
\hline
\end{tabular}

Middle and lower Malinau

Sentaban

24

$100 \quad 124$

Long Bila'

$\begin{array}{lll} & 124 & 124 \\ 681 & & 681\end{array}$

Setulan

Setarap

200

23

223

Punan Setarap

104

104

Batu Kajang

244

244

Gong Sulok

106

40

146

Long Adiu

97

Punan Long Adiu

67

Bila' Bekayuk (Loreh)

Liu Mahan (Loreh)

142

490

Pelencau (Loreh)

40

450

155 
APPENDICES

\begin{tabular}{|c|c|c|c|c|c|c|}
\hline VILLAGE & PUNAN & MERAP & PUTUK & KENYAH & ABAI & TOTAL \\
\hline \multicolumn{7}{|c|}{ Middle and lower Malinau (Continued) } \\
\hline Sengayan (Loreh) & & 125 & & & & 125 \\
\hline Long Loreh & & & & $?$ & & 0 \\
\hline Long Rat & 94 & & & & & 94 \\
\hline Laban Nyarit & $?$ & 86 & & & & 86 \\
\hline Nanuk Tanah Kibang & $?$ & 136 & & & & 136 \\
\hline Langap & & 364 & & & & 364 \\
\hline Tanjung Nanga & & & & 270 & & 270 \\
\hline \multirow[t]{2}{*}{ Paya Seturan } & $?$ & 63 & & $?$ & & 63 \\
\hline & 602 & 1001 & 200 & 1708 & 224 & 3735 \\
\hline
\end{tabular}

\begin{tabular}{|c|c|c|c|c|c|c|}
\hline \multicolumn{7}{|c|}{ Upper Malinau/Tubu } \\
\hline Halanga & 130 & & & & & 130 \\
\hline Punan Mirau & 74 & & & & & 74 \\
\hline Metut & 140 & & & & & 140 \\
\hline Long Lake & 217 & & & & & 217 \\
\hline Long Jalan & 127 & & & & & 127 \\
\hline Rian Tubu & 62 & & & & & 62 \\
\hline Long Titi & 77 & & & & & 77 \\
\hline Long Pada & 99 & & & & & 99 \\
\hline Long Nyau & 81 & & & & & 81 \\
\hline \multirow[t]{2}{*}{ Long Ranau } & 117 & & & & & 117 \\
\hline & 1124 & 0 & 0 & 0 & 0 & 1124 \\
\hline TOTAL & 2752 & 1095 & 1389 & 1708 & 344 & 7288 \\
\hline
\end{tabular}

\begin{tabular}{lrrrrrr}
\hline VILlAGE & PUNAN & MERAP & PUTUK & KENYAH & ABAI & TOTAL \\
\hline Kota Malinau area & $42 \%$ & $4 \%$ & $49 \%$ & $0 \%$ & $5 \%$ & $100 \%$ \\
Middle/Lower Malinau & $16 \%$ & $27 \%$ & $5 \%$ & $46 \%$ & $6 \%$ & $100 \%$ \\
Upper Malinau/Tubu & $100 \%$ & & & & & $100 \%$ \\
\hline
\end{tabular}

Above the population-figures for Liu Mahan are mainly counted as Kenyah. If this is true, than the population figure for Punan is much lower than I previously thought, and the Kenyah groups then constitute around $50 \%$ of the population in the middle Malinau, just as the Putuk constitute roughly $50 \%$ of the indigenous population in the Kota Malinau-Pulau Sapi-area (Figures based on statistics from the District office in Malinau in 1990-91). 


\section{Appendix 3. The Genealogy of Mpang Alang (Merap, Langap), with a few ethnohistoric notes}

I. Ncau Kincung

II. Nyihan Mau

III. Alang Nyihan

IV. Ncau Alang

V. Alang Ncau
Dayang Angung, his wife. According to Merap oral history, this divine couple gave birth to the first human Merap of royal origin.

The son of (the spiritual/divine beings called) Ncau Kincung and Dayang Angung.

The son of Nyihan Ncau. He may have lived close to the Berap River on the lower Lurah in the Bahau area.

At the time of Ncau Alang the Merap fled from the Lurah River, Bahau, to the upper Malinau, then Mentarang, Pa Upan, Kalun River (Tubu'). Ncau Alang died at Tukuk Apa'.

From Tukuk Apa' to Long Pada in the upper Tubu', then to Tukuk Nyurat on the Arah River, upper Malinau. From Tukuk Nyurat they moved to the upper Kulih River, then to Aking Dengon, close to Liu Mahan. It was probably during the time of Alang Ncau that the Merap began showing a growing interest in the birdnest caves in Seturan and Rian. This also led to conflicts with the Berusu'.

Alang Ncau was succeeded by his sister's son, Alang Mpang. The group moved to from Aking Dengon to Gunung Luhing. Here the group split. Arau Alang, brother of Lungu' 


\section{ApPendices}

Alang, moved to the Lue River (and moved later to the Hong River). The major group, headed by Alang Mpang, moved from Gunung Luhing to Gunung Bupah and then to Ngun Cibau.

VI. Lungu' Alang

From Ngun Cibau they moved to the Gunung Hut River, and a few years later to Long Pelencau. In order to get closer to the birdnest caves, they soon moved further downstream to Long Lemirang, then to Long Pasang and soon thereafter to Tabau Baung. Alang Mpang died in Tabau Baung.

Lungu' Alang and Alang Mpang established rights to the birdnest caves in Seturan and Rian. It was also Lungu' Alang who established a relation with the Malay petty kingdom headed by a Muslim king called Panembahan Raja Tua. At this time Arau Alang was settled on the upper Hong River, and Ibung Alang at Kuala Ran - both of them were brothers of Lungu'Alang.

Lungu' Alang died in Tabau Baung. He was succeeded by his younger brother, Ibung Alang. He established peace with neighboring groups, such as the Kayan Uma' Laran, and travels became safer and trade was easier. Ibung Alang was succeeded by Laing Lungu':

VII. Laing Lungu'

Laing Lungu' established (trade) relations with Penambahan Rajah Tua. In order to make their relations easier he moved from Tabau Baung to Jaukuya, and later to Langap. His younger brother, Ncau Lungu', split from the 


\section{ApPENDICES}

main group and established himself at Gunung Jaskau, Balah Uma' (Seturan River), where he guarded the Rattan Sega plantations.

When Penambahan Rajah Tua died, he was succeeded by Rajah Pendeta. It was also at this time that Laing Lungu' died in Langap, probably at the beginning of the 20th century, just before the arrival of the Dutch. Laing Lungu' was succeeded by his son, Kelit Laning (or Alang Laing?).

VIII. Alang Laing

Headman when the Dutch arrived around 1914. He became head of the Merap at the time when his father, Laing Lungu' died. It was particularly during this time that trade in bird nests and NTFPs became increasingly important. Various traders began to visit the villages upstream.

IX. Mpang Alang Born in Long Kelawit, died in Langap. The Dutch and the Sultan of Bulungan made him Kepala Besar Sungai Malinau/Tubu'. When he died he was succeeded by his son, Alang Mpang.

X. Alang Mpang Born in Liu Tanam, died in Langap. He was titled Rajah Besar Sungai Malinau. He had four children, Mpang Alang, Aran Alang, Nyihan Alang, and Lungu' Alang.

XI. Mpang Alang 
ApPendices

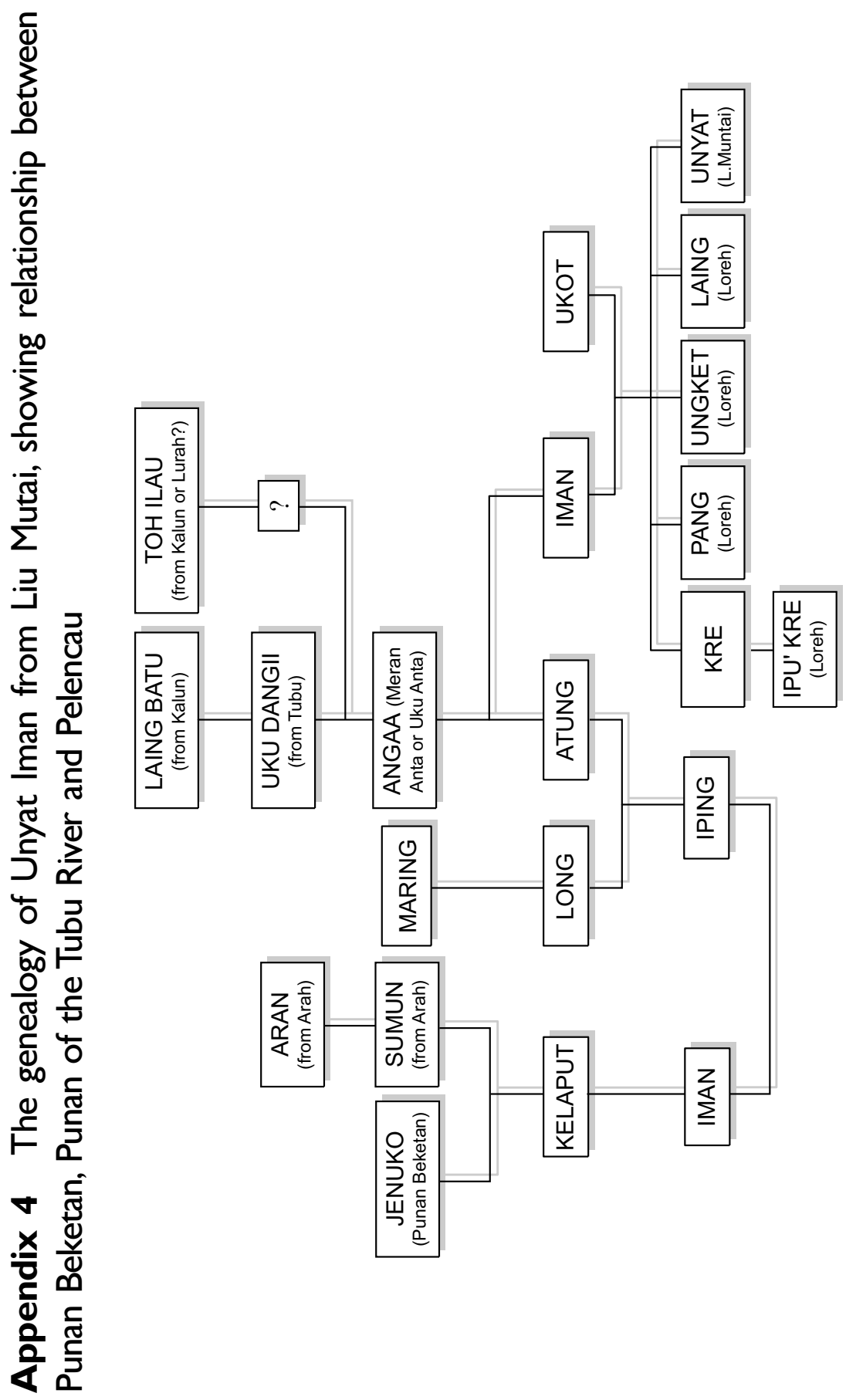




\section{APPENDICES}

\section{Appendix 5. The genealogy of Ncau Usat, Long Uli}

Born in Kalun Tubu. Met the Merap chief, Alang Ncau, and joined with him to the Malinau watershed. Impang Jalee died and was buried at Belatik mountain, located at the headwaters of the Afang and Kukan river, tributaries of the Hong River.

At the time of Adau Impang, the Merap were living at Aking Paha, upstream from Nkah Limpak, just across the river from the mouth of the Mekayan River. Paha is the name of the mountain.

Irang Urong died and was buried at Balau River, upstream from Long Keramu. At this time the Merap were living at Tabau Baung.

Amu' Irang died at Mekuling River, tributary of the Hong River.

Kelit Amu' moved to Metut and was also buried there.

Ncau Usat is living in Long Uli today.

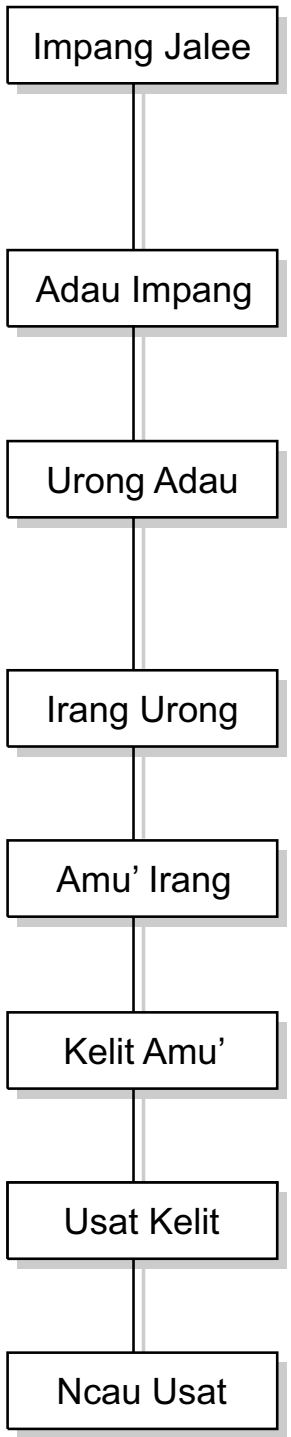


APPENDICES

Appendix 6. M'bui, apical forefather of Bare' Tangga'

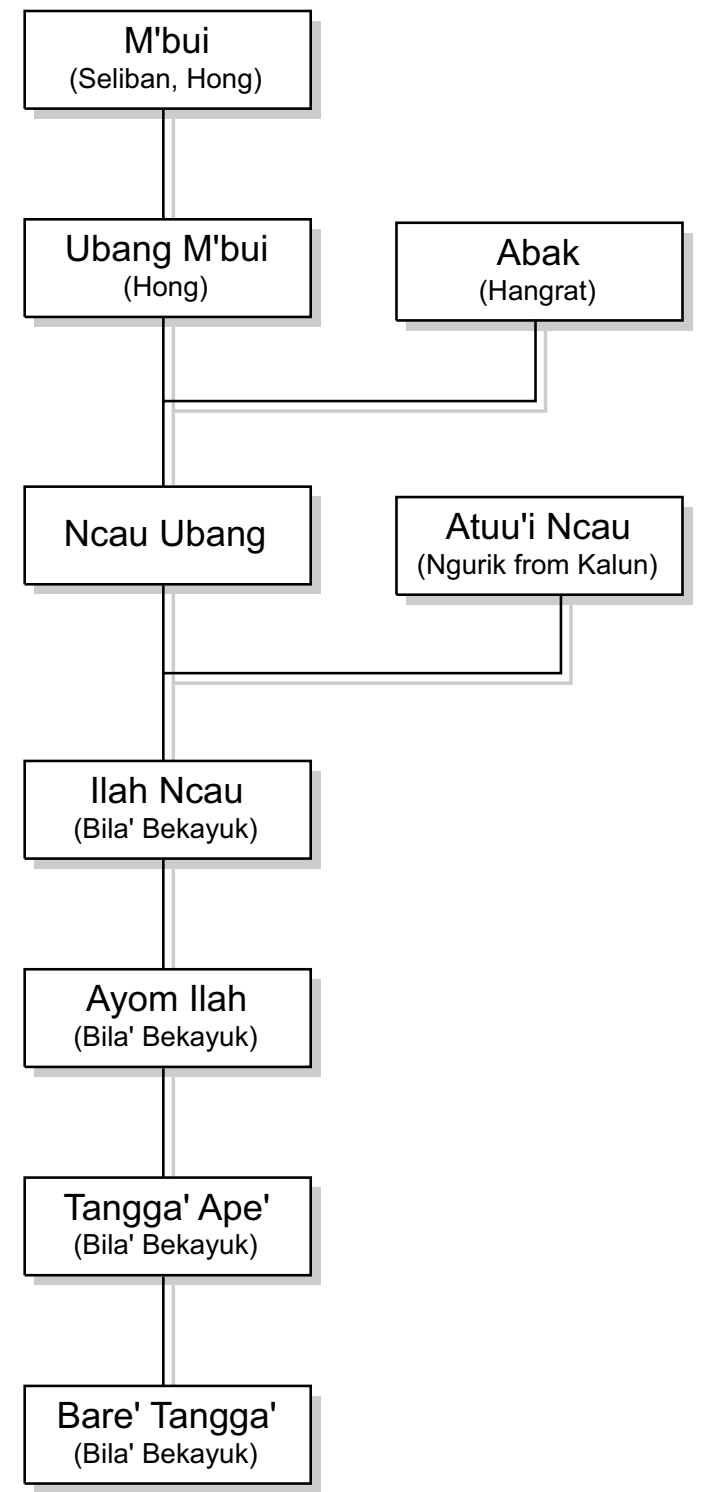


ApPendices

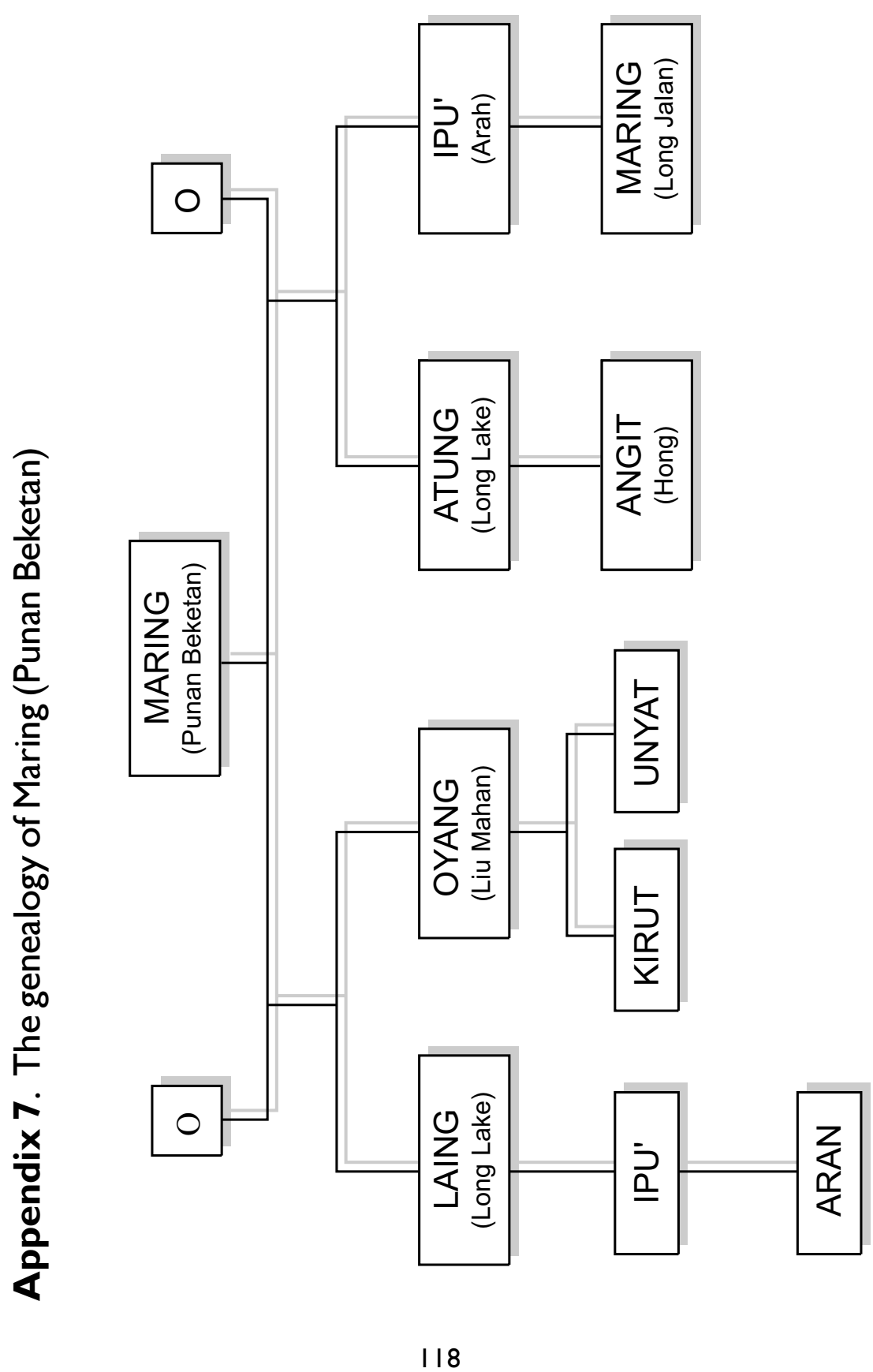


This book focuses primarily on changes that have taken place in the Malinau area in East Kalimantan in recent years. The Punan Malinau, who inhabit the area, are former nomads who subsist on a wide range of forest-oriented activities, including swidden agriculture, hunting and the collection of and trade in forest products. During the past ten years, the arrival of a growing number of powerful outsiders, including NGO's, timber and mining companies, has contributed to increasing competition for land and for various new sources of income. In the context of recent changes, local historical knowledge has become an increasingly important political asset. Such knowledge provides one way for local people to strengthen the legitimacy of their claims to land and forests.

\section{ISBN $9798764-90-0$}
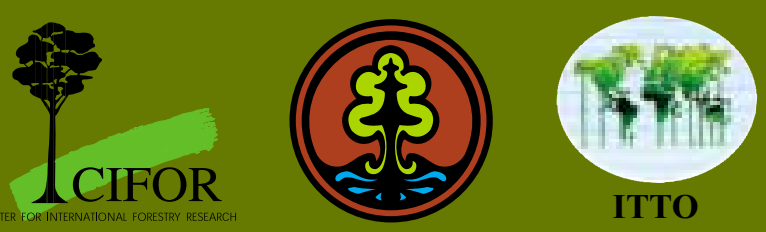